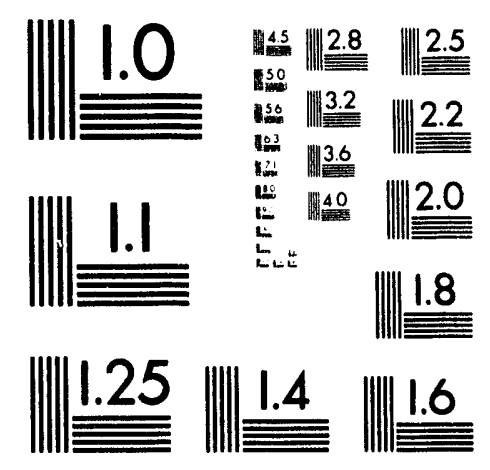



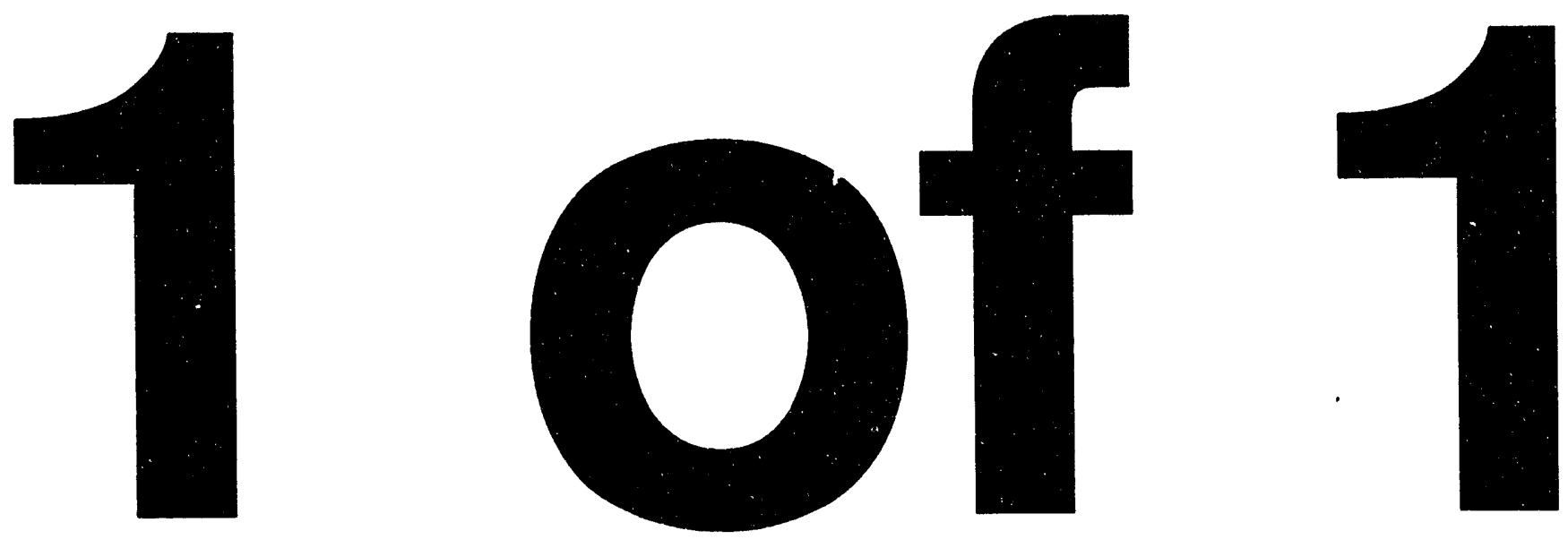


\title{
Summary of Activities to Remove the Aircraft Fuel Hydrant System (Panero Site) at March Air Force Base, California
}

\author{
G. L. Hendrian \\ Published June 1993 \\ Idaho National Engineering Laboratory \\ EG\&G Idaho, Inc. \\ Idaho Falls, Idaho 83415
}

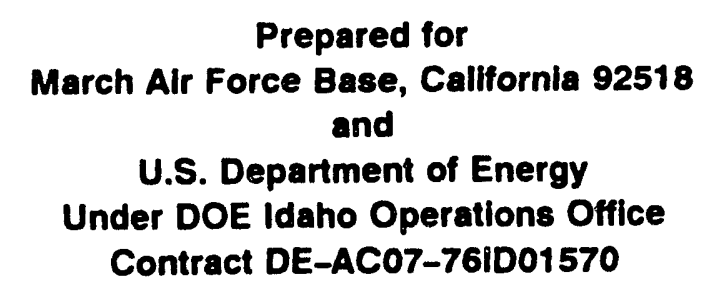

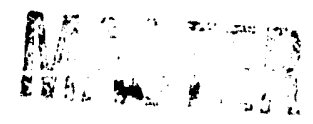

DISTRIEUTION OF THIS DOCUIMENT IS UNLIMITED 


\section{ABSTRACT}

This document summarizes the activities to remove the underground storage tank farm (Panero Site, Operable Unit 3, Installation Restoration Program) used for aircraft refueling at March AFB. A photographic and narrative presentation is employed. 


\section{CONTENTS}

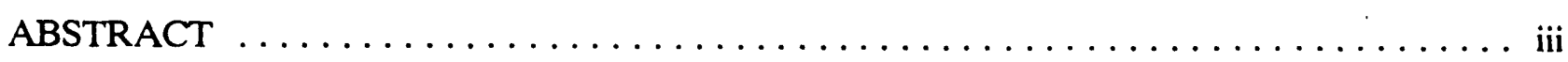

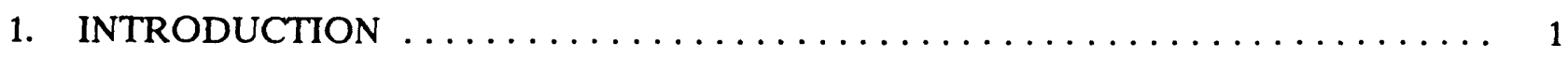

1.1 Summary of Existing Information $\ldots \ldots \ldots \ldots \ldots \ldots \ldots \ldots \ldots \ldots \ldots \ldots \ldots$

1.1.1 Panero Aircraft Refueling System Description . . . . . . . . . . . 1

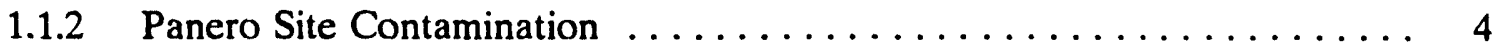

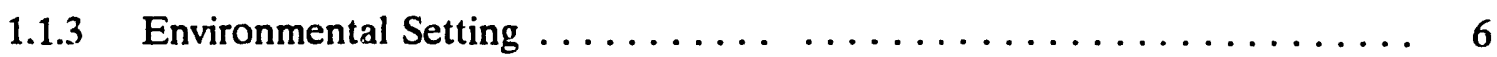

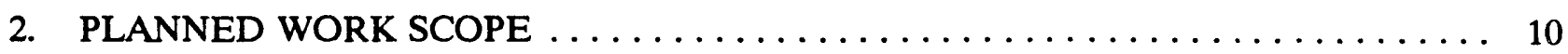

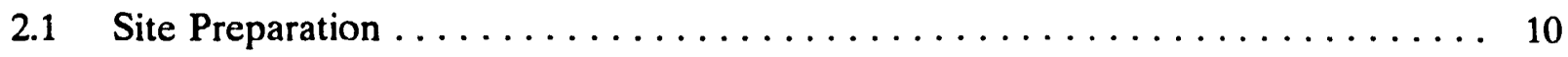

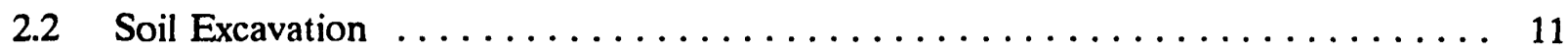

2.3 Hydrant and Piping Removal $\ldots \ldots \ldots \ldots \ldots \ldots \ldots \ldots \ldots \ldots \ldots \ldots \ldots$

2.4 Control Pit Removal $\ldots \ldots \ldots \ldots \ldots \ldots \ldots \ldots \ldots \ldots \ldots \ldots \ldots \ldots \ldots$

2.5 Electrical Pull Box Removal . . . . . . . . . . . . . . . . 19

2.6 Control Building Removal $\ldots \ldots \ldots \ldots \ldots \ldots \ldots \ldots \ldots \ldots \ldots \ldots \ldots \ldots$

2.7 Pump Gallery Removal $\ldots \ldots \ldots \ldots \ldots \ldots \ldots \ldots \ldots \ldots \ldots \ldots \ldots \ldots$

2.8 Vapor Recovery Unit Removal $\ldots \ldots \ldots \ldots \ldots \ldots \ldots \ldots \ldots \ldots \ldots \ldots$

2.9 Defueling Tank Removal $\ldots \ldots \ldots \ldots \ldots \ldots \ldots \ldots \ldots \ldots \ldots \ldots \ldots \ldots$

2.10 Underground Piping Removal and Abandonment $\ldots \ldots \ldots \ldots \ldots \ldots$

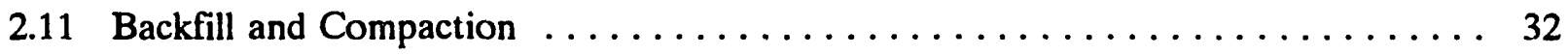

3. DEMOLITION RESULTS $\ldots \ldots \ldots \ldots \ldots \ldots \ldots \ldots \ldots \ldots \ldots \ldots \ldots \ldots \ldots \ldots$

3.1 Transformer and Rectifier Analysis $\ldots \ldots \ldots \ldots \ldots \ldots \ldots \ldots \ldots \ldots \ldots \ldots$

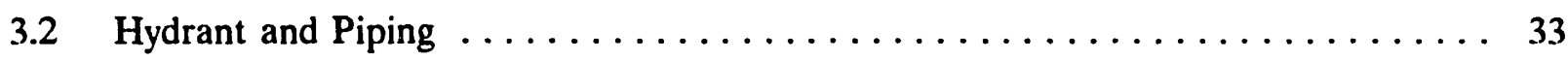

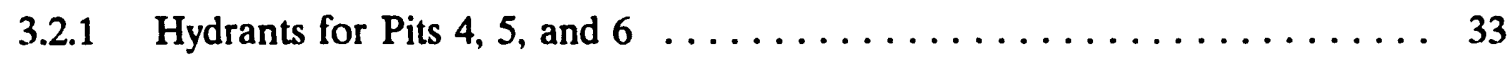

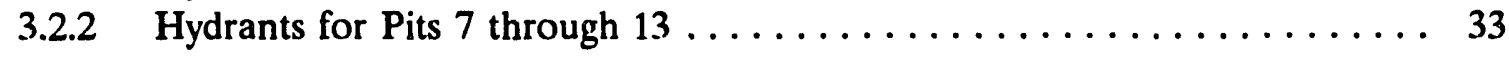

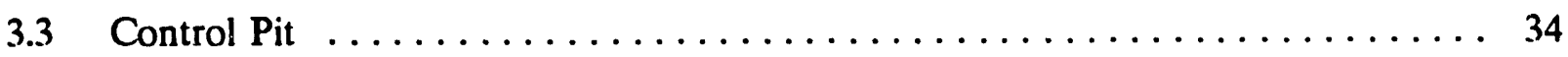




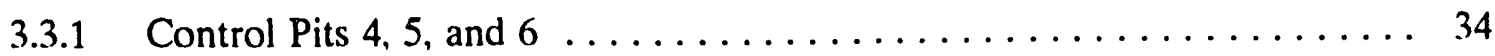

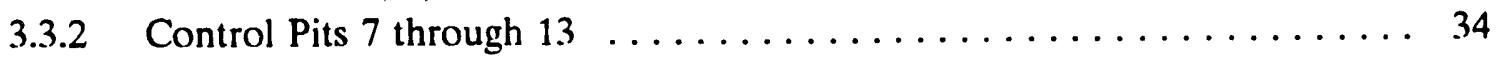

3.4 Electrical Pull Boxes $\ldots \ldots \ldots \ldots \ldots \ldots \ldots \ldots \ldots \ldots \ldots \ldots \ldots \ldots \ldots$

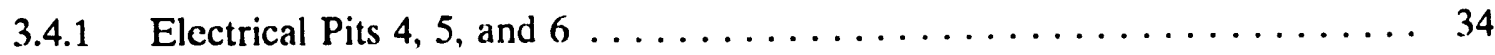

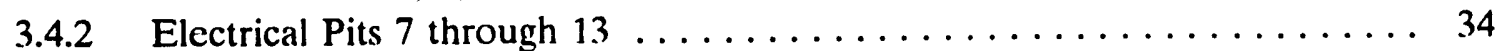

3.5 Control Building $\ldots \ldots \ldots \ldots \ldots \ldots \ldots \ldots \ldots \ldots \ldots \ldots \ldots \ldots \ldots \ldots \ldots \ldots$

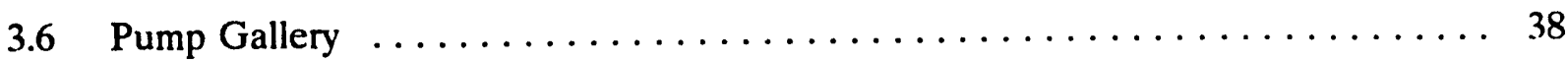

3.7 Vapoi Recovery Unit $\ldots \ldots \ldots \ldots \ldots \ldots \ldots \ldots \ldots \ldots \ldots \ldots \ldots \ldots \ldots$

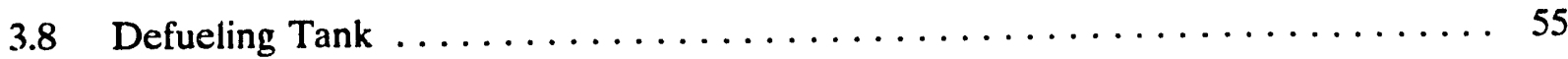

3.9 Underground Piping $\ldots \ldots \ldots \ldots \ldots \ldots \ldots \ldots \ldots \ldots \ldots \ldots \ldots \ldots$

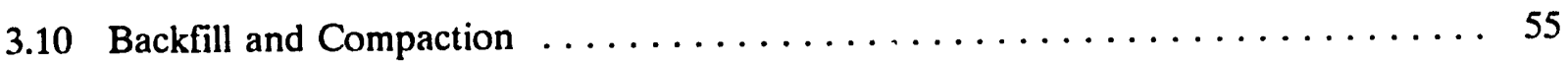

4. WASTE REDUCTION ACTIONS $\ldots \ldots \ldots \ldots \ldots \ldots \ldots \ldots \ldots \ldots \ldots \ldots \ldots$

REFERENCES $\ldots \ldots \ldots \ldots \ldots \ldots \ldots \ldots \ldots \ldots \ldots \ldots \ldots \ldots \ldots \ldots \ldots$

\section{FIGURES}

1. Location of March AFB, California $\ldots \ldots \ldots \ldots \ldots \ldots \ldots \ldots \ldots \ldots \ldots \ldots \ldots$

2. Panero Site on March AFB, California $\ldots \ldots \ldots \ldots \ldots \ldots \ldots \ldots \ldots \ldots \ldots \ldots \ldots$

3. Panero underground refueling site configuration $\ldots \ldots \ldots \ldots \ldots \ldots \ldots \ldots \ldots$

4. Suspected extent of free product it the Panero Site $\ldots \ldots \ldots \ldots \ldots \ldots \ldots \ldots \ldots$

5. Location of east March AFB within the San Jacinto Watershed (modified from Engineering-Science 1988) $\ldots \ldots \ldots \ldots \ldots \ldots \ldots \ldots \ldots \ldots \ldots \ldots \ldots$

6. Access to fuel hydrant $\ldots \ldots \ldots \ldots \ldots \ldots \ldots \ldots \ldots \ldots \ldots \ldots \ldots \ldots \ldots \ldots \ldots$

7. Access to a hydrant electrical connector $\ldots \ldots \ldots \ldots \ldots \ldots \ldots \ldots \ldots \ldots \ldots \ldots$

8. External view of a control pit $\ldots \ldots \ldots \ldots \ldots \ldots \ldots \ldots \ldots \ldots \ldots \ldots \ldots \ldots$

9. Interior view of a control pit $\ldots \ldots \ldots \ldots \ldots \ldots \ldots \ldots \ldots \ldots \ldots \ldots \ldots \ldots$

10. Exterior of a control pit $\ldots \ldots \ldots \ldots \ldots \ldots \ldots \ldots \ldots \ldots \ldots \ldots \ldots \ldots \ldots$ 
11. Controls, valves, and pipes inside a control pit $\ldots \ldots \ldots \ldots \ldots \ldots \ldots \ldots \ldots$

12. Further view of the internals of a control pit $\ldots \ldots \ldots \ldots \ldots \ldots \ldots \ldots \ldots \ldots$

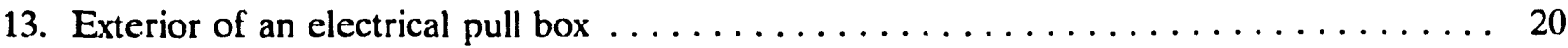

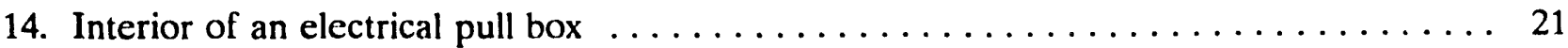

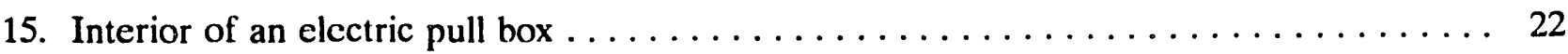

16. Office area in the control building $\ldots \ldots \ldots \ldots \ldots \ldots \ldots \ldots \ldots \ldots \ldots \ldots \ldots$

17. Electrical control panel in the control building $\ldots \ldots \ldots \ldots \ldots \ldots \ldots \ldots \ldots$

18. Area containing transformers in the control building $\ldots \ldots \ldots \ldots \ldots \ldots \ldots \ldots \ldots$

19. North and south pump gallery and control building viewed from the east $\ldots \ldots \ldots \ldots$

20. North pump gallery prior to demolition $\ldots \ldots \ldots \ldots \ldots \ldots \ldots \ldots \ldots \ldots \ldots$

21. South pump gallery prior to demolition $\ldots \ldots \ldots \ldots \ldots \ldots \ldots \ldots \ldots \ldots \ldots$

22. Individual pump and separator unit within the pump gallery $\ldots \ldots \ldots \ldots \ldots \ldots$

23. The Vapor Recovery Unit that was located northeast of the control building and pump

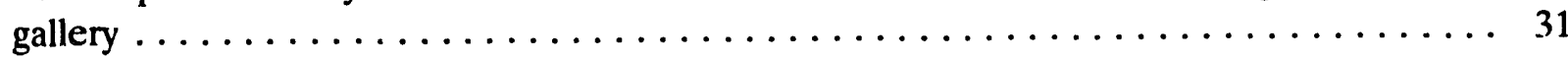

24. Removal of surface concrete around the control pits. ............... 35

25. Excavation of uidderground fuel lines. $\ldots \ldots \ldots \ldots \ldots \ldots \ldots \ldots \ldots \ldots \ldots \ldots$

26. Containment fence/screen used to prevent unwanted distribution of excavation material . . 37

27. Demonstration of attaching the pull cable to the electrical wiring for removal. . . . . . 39

28. Depiction of one run of electrical wire that has been removed from the underground conduit. The pickup truck is ready to pull another run. $\ldots \ldots \ldots \ldots \ldots \ldots \ldots$

29. Control building during demolition. The plastic tunnel was installed to prevent the disbursement of the asbestos contained in the floor tile and adhesive. . . . . . . $\ldots 41$

30. Demolition of the control building. $\ldots \ldots \ldots \ldots \ldots \ldots \ldots \ldots \ldots \ldots \ldots \ldots \ldots \ldots$

31. Demolition of the control building. $\ldots \ldots \ldots \ldots \ldots \ldots \ldots \ldots \ldots \ldots \ldots \ldots \ldots$

32. Salvaged electrical control panel from the control building being transported to the DRMO storage area. . . . . . . . . . . . . . . . . . . . . . . 
33. Pump gallery after removal of separator tanks and associated pipelines. . . . . . 45

34. Pump gallery after removal of aboveground equipment and roof. . . . . . . . 46

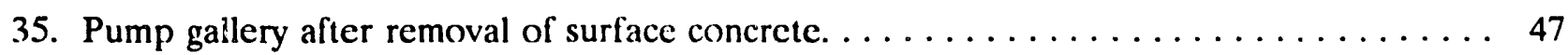

36. Cleaning the 50,000 -gal tanks to remove all traces of the fuel. $\ldots \ldots \ldots \ldots \ldots$

37. Exposing the 50,000 -gal fuel tanks. $\ldots \ldots \ldots \ldots \ldots \ldots \ldots \ldots \ldots \ldots \ldots \ldots \ldots$

38. Initial excavation of the 50,000 -gal underground storage tanks. $\ldots \ldots \ldots \ldots \ldots$

39. View showing exposed space between tanks. $\ldots \ldots \ldots \ldots \ldots \ldots \ldots \ldots \ldots \ldots \ldots$

40. Area after the removal of several 50,000 -gal tanks. $\ldots \ldots \ldots \ldots \ldots \ldots \ldots \ldots \ldots$

41. Concrete saddle of the 50,000 -gal tank. $\ldots \ldots \ldots \ldots \ldots \ldots \ldots \ldots \ldots \ldots \ldots \ldots$

42. Lifting the 50,000 -gal tank from the ground. $\ldots \ldots \ldots \ldots \ldots \ldots \ldots \ldots \ldots$

43. Removing the liquid and vapor from the underground pipes. $\ldots \ldots \ldots \ldots \ldots$

44. Exposing the underground pipelines. $\ldots \ldots \ldots \ldots \ldots \ldots \ldots \ldots \ldots \ldots \ldots \ldots$

45. Open trench showing exposed underground pipes and excavation material along the trench. This covering and contaminant control procedure is typical of the safety practices employed to prevent undesired distribution of excavated material. $\ldots \ldots \ldots \ldots \ldots \ldots$

46. Backfill and grading of the underground pipcline section. $\ldots \ldots \ldots \ldots \ldots \ldots$

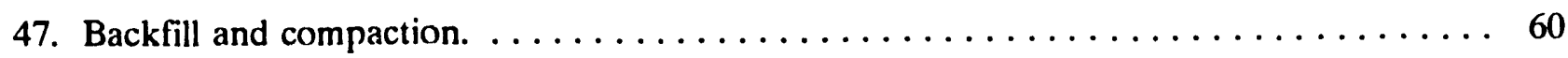

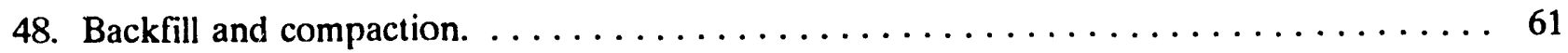

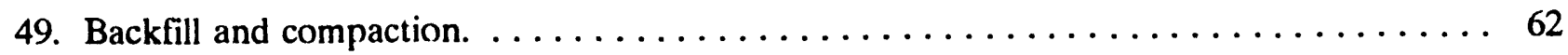

50. Backfill and compaction. $\ldots \ldots \ldots \ldots \ldots \ldots \ldots \ldots \ldots \ldots \ldots \ldots \ldots \ldots \ldots \ldots \ldots \ldots \ldots \ldots$

51. Depiction of soil sample acquisition. The samples were immediately taken to a mobile field laboratory located on MAFB and the samples analyzed for petroleum contaminates. The contaminated soil was treated onsite by a low-temperature process to remove the petroleum contaminates. The treated soil was then used as backfill in the underground

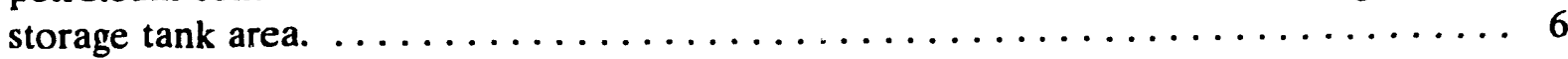

52. Recycled material from the demolition. $\ldots \ldots \ldots \ldots \ldots \ldots \ldots \ldots \ldots \ldots$

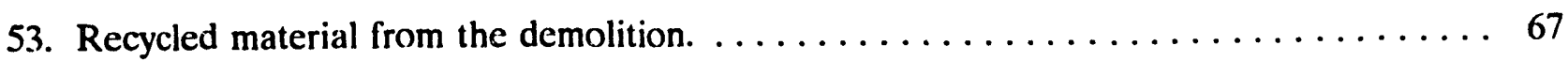


54. Recycled material from the demolition.

55. Kecycled material from the demolition 


\section{Summary of Activities to Remove the Aircraft Fuel Hydrant System (Panero Site) at March Air Force Base, California}

\section{Introduction}

This document is the summary of the work planned and the work completed on the removal of the Panero Sitc (Operable Unit 3, Installation Restoration Program [IRP], Site 33) Aircraft Fuel Hydrant System at March Air Force Base, California (March AFB). This site is a former aircraft refueling facility. This document has been prepared by the Idaho National Engincering Laboratory (INEL) for the U.S. Air Force and the Department of Defense Installation Restoration Program.

This summary report is organized into four sections:

- Introduction-Gives the scope, information summary, and composition of the report.

- $\quad$ Planned Work Scope-States the scope of work as provided in the Performance Work Statement for Removal of Aircraft Fuel Hydrant System March Air Force Base, California.

- Demolition Results-Records the accomplishments for each task defined in the Performance Work Statement.

- Recycling Efforts-Record the efforts to reduce generating unnecessary waste.

This report will document the removal of the Aircraft Fuel Hydrant System through narration and photographs.

\subsection{Summary of Existing Information}

This section presents information regarding the background and environmental setting of the Panero Site. General information regarding the background and environmental setting for the Base is presented in the Base-wide RI/FS work plan for March AFB (Earth Technology Corporation 1992).

\subsubsection{Panero Aircraft Refueling System Description}

March AFB is located approximately 60 miles east of Los Angeles and 90 miles north of San Diego in Riverside, California (Figure 1). The eastern half of the base, on which the Panero Site is located, lies within the San Jacinto watershed. This is a major subdivision of the Santa Ana River Basin. The Panero aircraft fueling sysiem site occupies about 45 acres on the eastern half and has served March AFB fueling activities since its installation in 1952 (Figure 2). Fucling activities at the Panero Site ceased in the summer of 1991. 


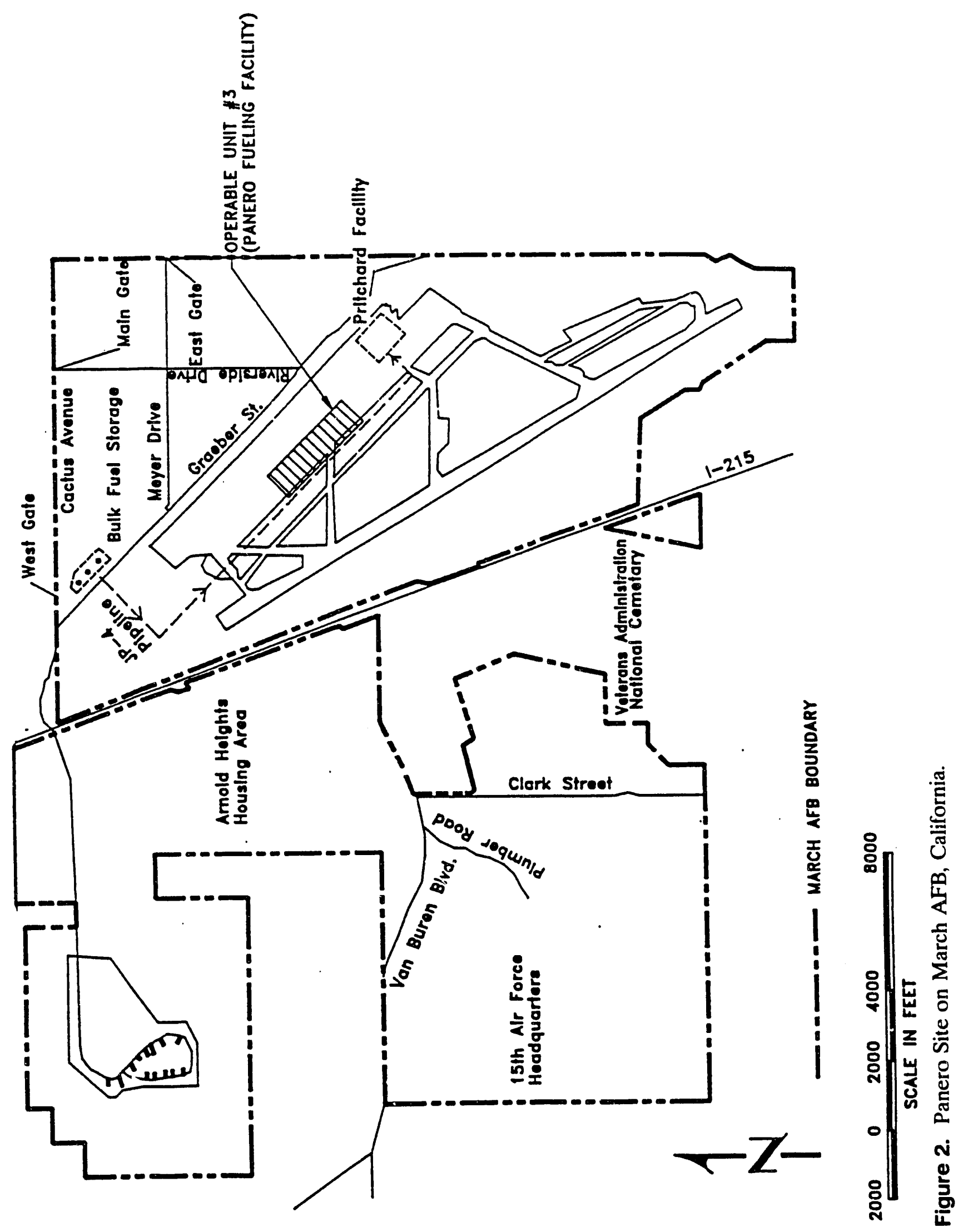


The aircraft fuel system consisted of $3450,00()$-gal underground storage tanks; one 25,000-gal underground defucling tank located next to control pit 13; a vapor recovery unit with a 550 -gal underground tank: a distribution system that included a pump house with $346(0)-\mathrm{gal} / \mathrm{min}$ pumps, associated filter and separator units. and control equipment; 20 hydrants and lateral control pits, and; approximatcly $7.500 \mathrm{ft}$ of pipcline. The system received fucl from the bulk storage area located about $6,000 \mathrm{ft}$ northwest of the Panero Site.

The configuration of the underground tank farm is shown in Figure 3. When the system was originally installed in 1952, the tank farm consisted of 40 underground tanks. In 1962, six tanks were removed and transferred to the Pritchard refucling area. The remaining 34 tanks are $64 \mathrm{ft}$ long and $11.5 \mathrm{ft}$ in diameter with the bottom of the tank approximately $16 \mathrm{ft}$ below the ground surface. The tanks rest on curved concrete saddles.

Fuel used at the site flowed to the refucling hydrants from the pump house, which was at ground level immediatcly above the underground tank farm. Excess fuel in the fuel distribution lines following refucling activities drained to the 25.000 -gal defueling tank located at the southeast end of the site. The fuel that accumulated in the 25,000 -gal defueling tank was pumped into Tank 20 via the return line.

Three separate pipelines were present at the facility to the southeast of the pump house. They were vertically aligned and spaced about $1 \mathrm{ft}$ apart in a filled trench beneath the control pits and, except for the defueling line, ran from the pump house to control pit 13. The defucling line ran between control pits 7 and 13. Excess fuel in the distribution lines to the northwest of the pump house was gravity drained to Tank 19 at the pump house. Only two pipelines were present to the northwest of the pump house. These lines were vertically aligned in a filled trench beneath the control pits and ran between the pump house and control pit 4 .

The 25,000-gal underground defueling tank was located at Pad 13 and the 550-gal vapor recovery tank was located next to the vapor recovery unit northeast of the 34-tank system. All tanks at the Panero Site have reportedly contained only JP-4 fuel since their installation.

\subsubsection{Panero Site Contamination}

In 1987, fuel odors and stained soils were observed in the area of the underground storage tank farm. Subsequent laboratory analysis of soil samples indicated the presence of petroleum hydrocarbons in excess of $9,000 \mathrm{mg} / \mathrm{kg}(\mathrm{ppm})$.

Soil gas analysis of additional shallow samples indicated the presence of moderate to high jet fuel contamination south and west of the pump house. Analysis of deeper soil gas samples indicated more extensive contamination. Concentrations in excess of $136,000 \mu \mathrm{g} / \mathrm{L}$ were detected near Tank 1 at the 7-14 ft level. High concentrations were detected near control pits 5 and 6 in excess of $50,000 \mu \mathrm{g} / \mathrm{L}$. 

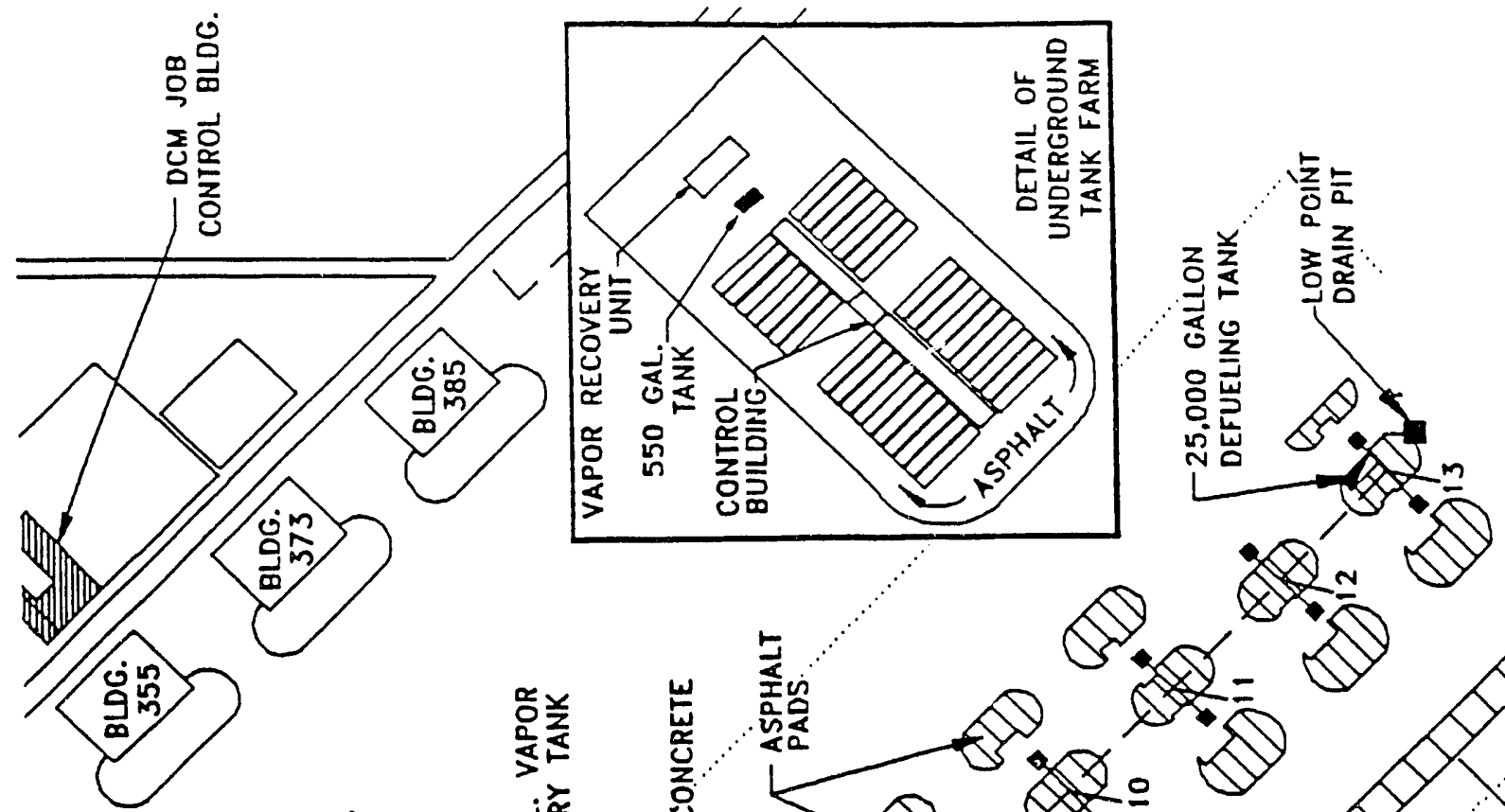
Several monitoring wells were installed and additional soil samples were taken during 1987-1992 to determine the extent of the contamination. Figure 4 shows the free product area contaminating the ground water. EG\&G Idaho (1991), March Air Force Base Operable Unit 3 (Panero Site) Remedial Investigation/Feasibility Study Work Plan Addendum, provides full details on the contamination.

\subsubsection{Environmental Setting}

Material presented in this section on the general environmental setting of March AFB has been taken from a published report (Earth Technology Corporation 1989). A comprehensive discussion of the ge graphic setting, history, geology, hydrogeoiogy, meteorology, and ecology of the Base is detailed in the Base-wide RI/FS work plan (Earth Technology Corporation 1992).

1.1.3.1 Geographic Setting. The eastern portion of March AFB, on which the Panero Site is located, lies in the northern end of the Perris Valley (Figure 5). This is a semi-arid, generally north-south running, alluvial valley. It is bounded by low-lying granite bedrock on the west and a series of tributary valleys and granite mountains on the east. Perris Valley is a sub-basin of the San Jacinto watershed, one of the three major geographical subdivisions of the Santa Ana Basin.

Regionally, the elevation of the floor of the Perris Valley ranges from about 1,400 to $1,700 \mathrm{ft}$ above sea level. The Perris Surface lies approximately $300 \mathrm{ft}$ above the valley floor. Elevations at the Panero Site range from about $1,525 \mathrm{ft}$ at the northernmost end to about $1,510 \mathrm{ft}$ at the southernmost end.

Additional information on the geographic setting at March AFB is in the Base-wide RI/FS work plan (Earth Technology Corporation 1992).

1.1.3.2 Geology. Regionally, the geology near March AFB is igneous and metamorphic crystalline rock overlain by or outcropping through alluvial soil. The Perris Block is an eroded mass of cretaceous and older crystalline rock that has been repeatedly uplifted by tectonic activity. This has resulted in a number of exposed erosional surfaces.

Locally, March AFB is located on two geologic areas of the Perris Block region. The western portion of the base lies on the Perris Surface, which consists of outcrops of crystalline igneous and metamorphic bedrock in the Perris Valley. The eastern portion of the base, on which the Panero Site is located, consists of alluvial deposits overlying the crystalline bedrock. The areas are divided by a crystalline rock outcrop line that runs north-northwest through the base.

Additional information regarding the geology of March AFB is in the Base-wide RI/FS work plan (Earth Technology Corporation 1992). 


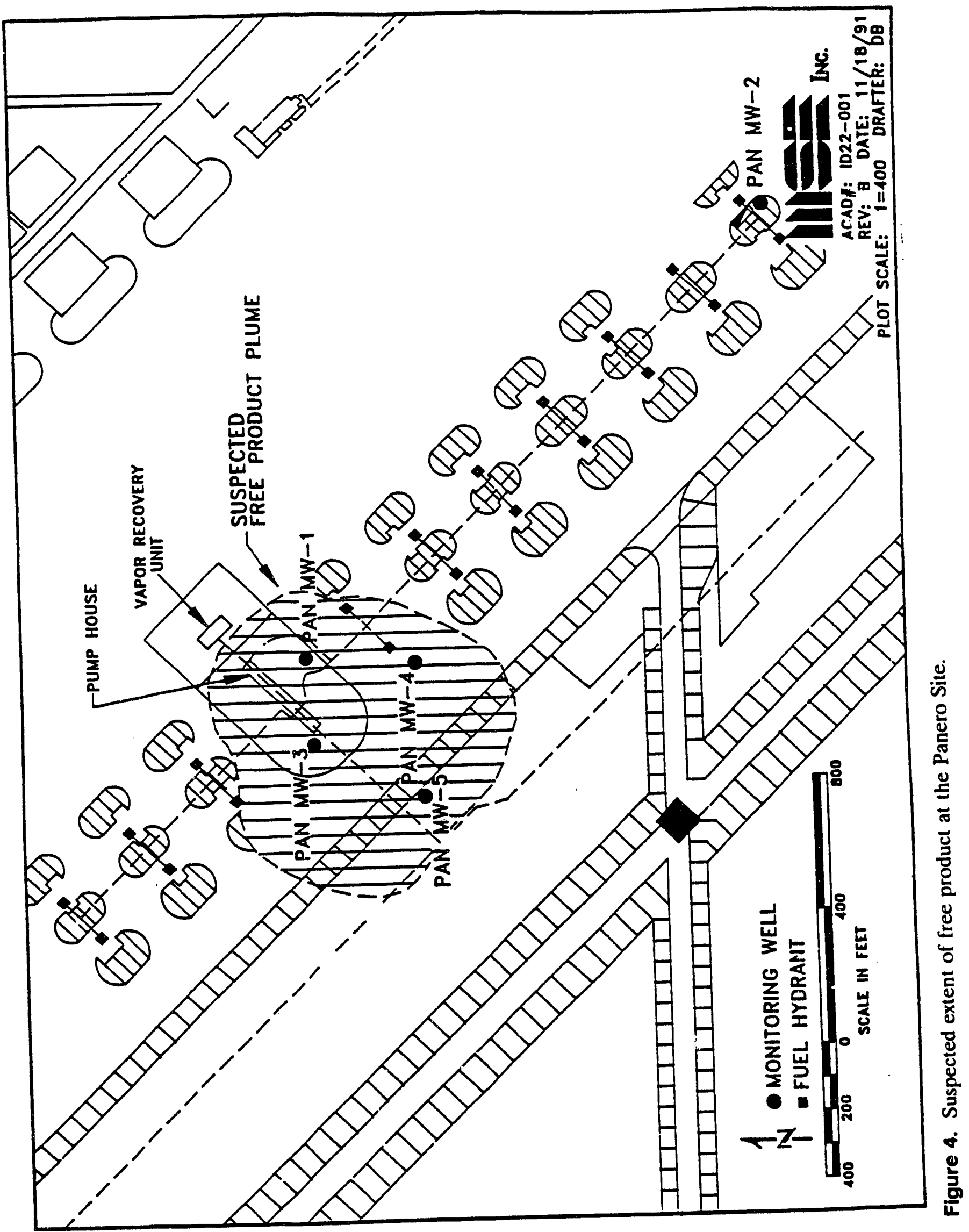




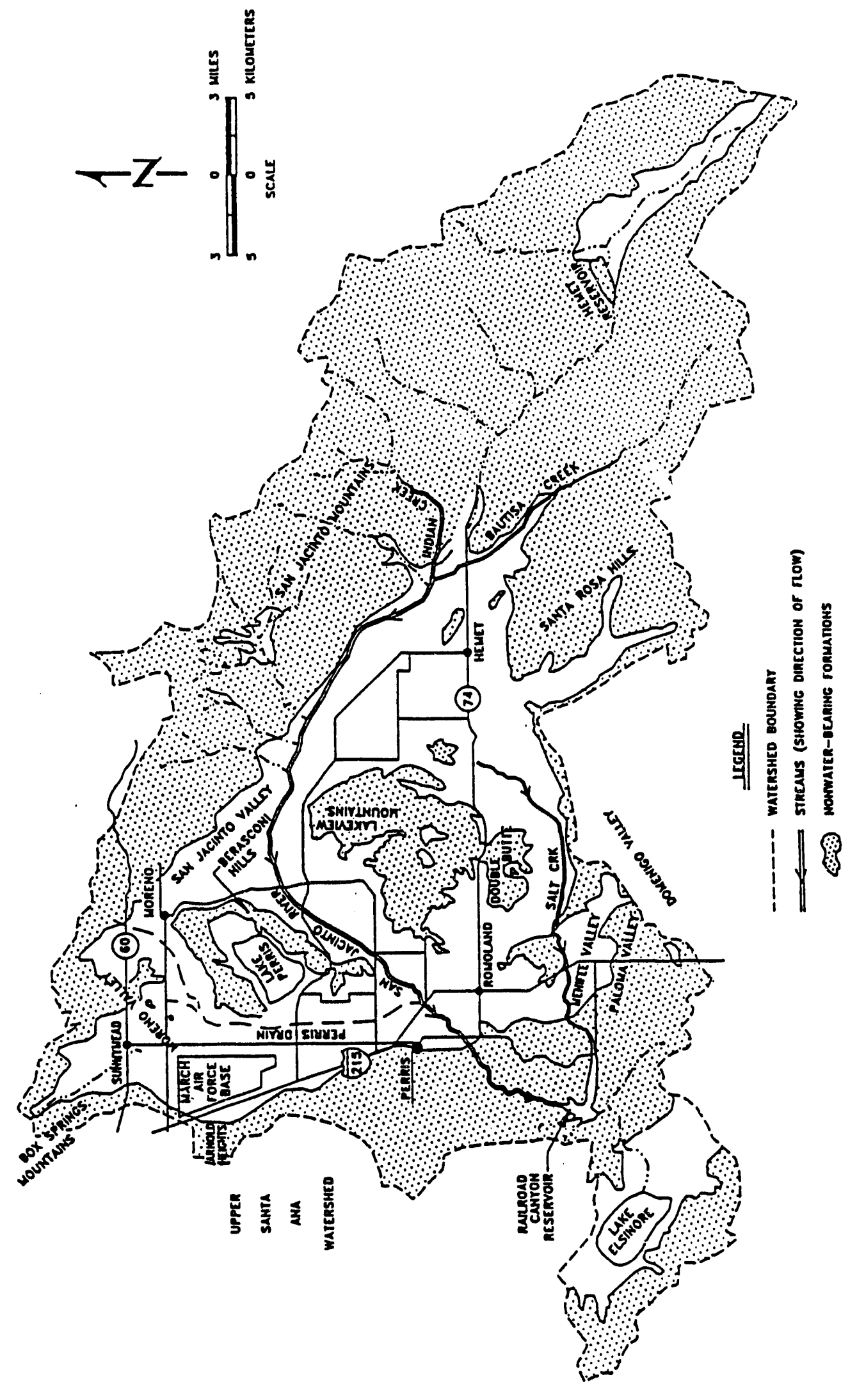

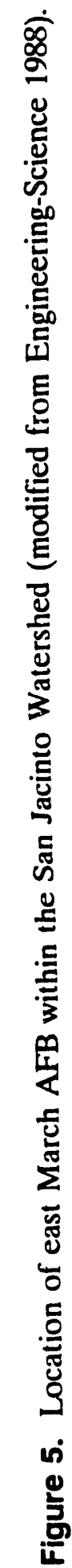


1.1.3.3 Hydrogeology. Regionally, March AFB is located in portions of the Perris and Moreno Valleys. which form the western part of the San Jacinto Watershed. Both valleys are characterized as broad, alluvial-lilled valleys that are underlain and surrounded by crystalline bedrock. Groundwater occurs in both the crystalline bedrock and alluvial deposits. Except for groundwater occurring in joints or fracture zones, the bedrock is essentially considered nonwater bearing. Ground water may be present in the weathered zones that exist near the bedrock-alluvium contact. Regional groundwater flows appear to be primarily toward the southeast, through the base, from recharge areas west and northwest of the site (Figure 5).

Locally, groundwater in the eastern portion of the base occurs primarily in the alluvial deposits. The permeability of the alluvium in this portion of the base increases with depth. Groundwater movement is affected by surface and bedrock topography and, perhaps, by artificial recharge. Artificial recharge from base sources reportedly occurs near the central portion of the base shop and housing areas and infiltration from the golf course, cemetery, and Heacock storm drain located on the north and east sides of the main base (Engineering-Science 1988).

Groundwater movement in this portion of the base appears to be to the northeast and southeast, suggesting the presence of a grouridwater divide. At the Panero Site itself, groundwater flow appears to be to the northeast in the northern part of the Site and to the southeast in the southern part. Because of the limited groundwater elevation data, the potential impact of seasonal fluctuations on the direction of flow at the Panero Site is unknown.

Detailed meteorologic and ecologic information at March AFB is provided in the Base-wide RI/FS work plan (Earth Technology Corporation 1992). 


\section{PLANNED WORK SCOPE}

Gysler (1990) details the work scope for the Pancro Site. Additional details pertaining to the planned removal activities are also presented in the full document (Gysler 1990).

The demolition of the Aircraft Fuel Hydrant System consisted of the following tasks:

- $\quad$ Site preparation

- Soil excavation

- Removal of the following:

- $\quad$ Hydrants and associated piping

- $\quad$ Control pits

- $\quad$ Electric pull boxes

- Control building

- $\quad$ Pump galleries

- Vapor recovery unit

- Defueling components and associated underground pipelines

- Some underground pipelines were sealed and abandoned

- All excavations were backfilled.

The following sections provide details of each task.

\subsection{Site Preparation}

- Temporary Barricades-A 4-ft high rope barrier shall be installed to isolate all excavations and work areas. Red flashing lights will be used at 20 -ft intervals around excavations and work areas.

- Sample Transformers-Test the transformer coolant for polychlorinated biphenyls (PCBs). 


\subsection{Soil Excavation}

- Sample Soil-Sample all soil to be removed and determine the disposition of the soil.

- Excavate Soil-Excavate the soil to expose the components of the fucl system and deliver to the appropriate areas. Soil containing petroleum contaminates will be segregated from clean soil and the contaminates will be removed.

\subsection{Hydrant and Piping Removal}

- $\quad$ Remove Cover and Fittings-Remove the cover and seat from the concrete for pits 4A and $4 \mathrm{~B}, 5 \mathrm{~A}$ and $5 \mathrm{~B}$, and $6 \mathrm{~A}$ and $6 \mathrm{~B}$. Remove all fittings in all pits. Replace the covers, if removed, on pits $7 \mathrm{~A}$ through $13 \mathrm{~B}$.

- Remove Supply Line-Remove the fiberglass fuel line from control pits 4, 5, and 6 to the adjacent hydrants. Access to the fuel hydrent is shown in Figure 6.

- Remove Electrical Connector-Remove the electrical connector and the metal housing located adjacent to hydrant pits $4 \mathrm{~A}$ and $4 \mathrm{~B}, 5 \mathrm{~A}$ and $5 \mathrm{~B}$, and $6 \mathrm{~A}$ and $6 \mathrm{~B}$. Access to a hydrant electrical connector is shown in Figure 7.

- $\quad$ Remove Concrete Pit-Remove the concrete box that houses the hydrant fittings at pits $4 \mathrm{~A}$ and $4 \mathrm{~B}, 5 \mathrm{~A}$ and $5 \mathrm{~B}$, and $6 \mathrm{~A}$ and $6 \mathrm{~B}$.

\subsection{Control Pit Removal}

Typical Control Pit configuration is shown in Figures 8 through 12.

- Remove Components-Remove the lid panels, piping, electrical fixtures, valves, meters, venting system, water lines, access ladder, cathodic protection aluminum anodes, and cover panel metal supports.

- Cap Piping-At control pits 7 through 13, cap all piping at the point nearest the pit walls.

- Cut and Cap Piping-At control pits 4, 5, and 6 excavate and cut the fuel lines, water line, and sewer line. Cap the sewer lines at the excavation boundary. Remove the water lines and the water line tap to the fire main and cap and plug as required.

- $\quad$ Remove Concrete-Remove the concrete structure of control pits 4, 5, and 6 .

- $\quad$ Replace Covers-Replace the covers on the tops of control pits 7 through 13. 


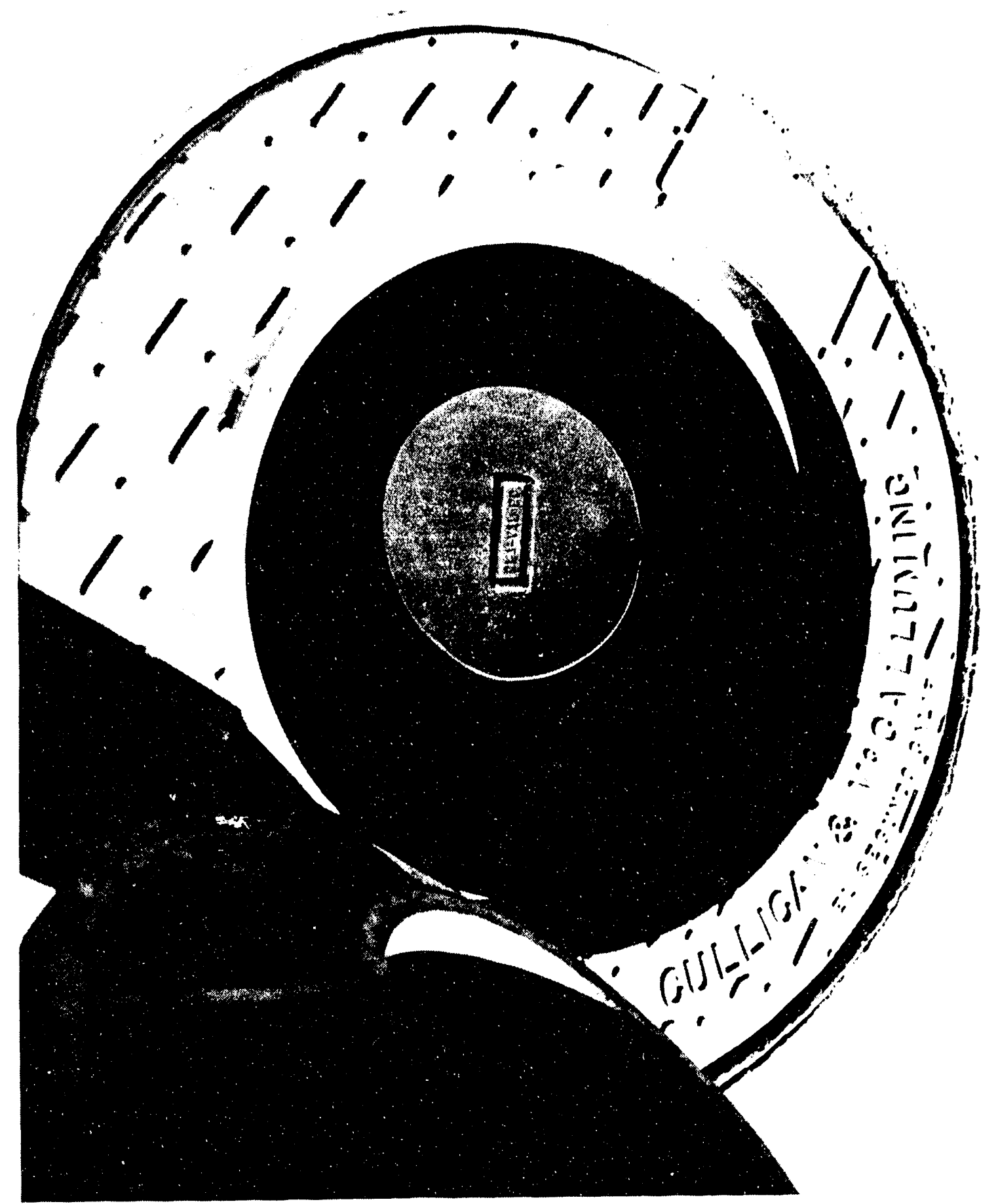

Figure 6. Access to fuel hydrant. 


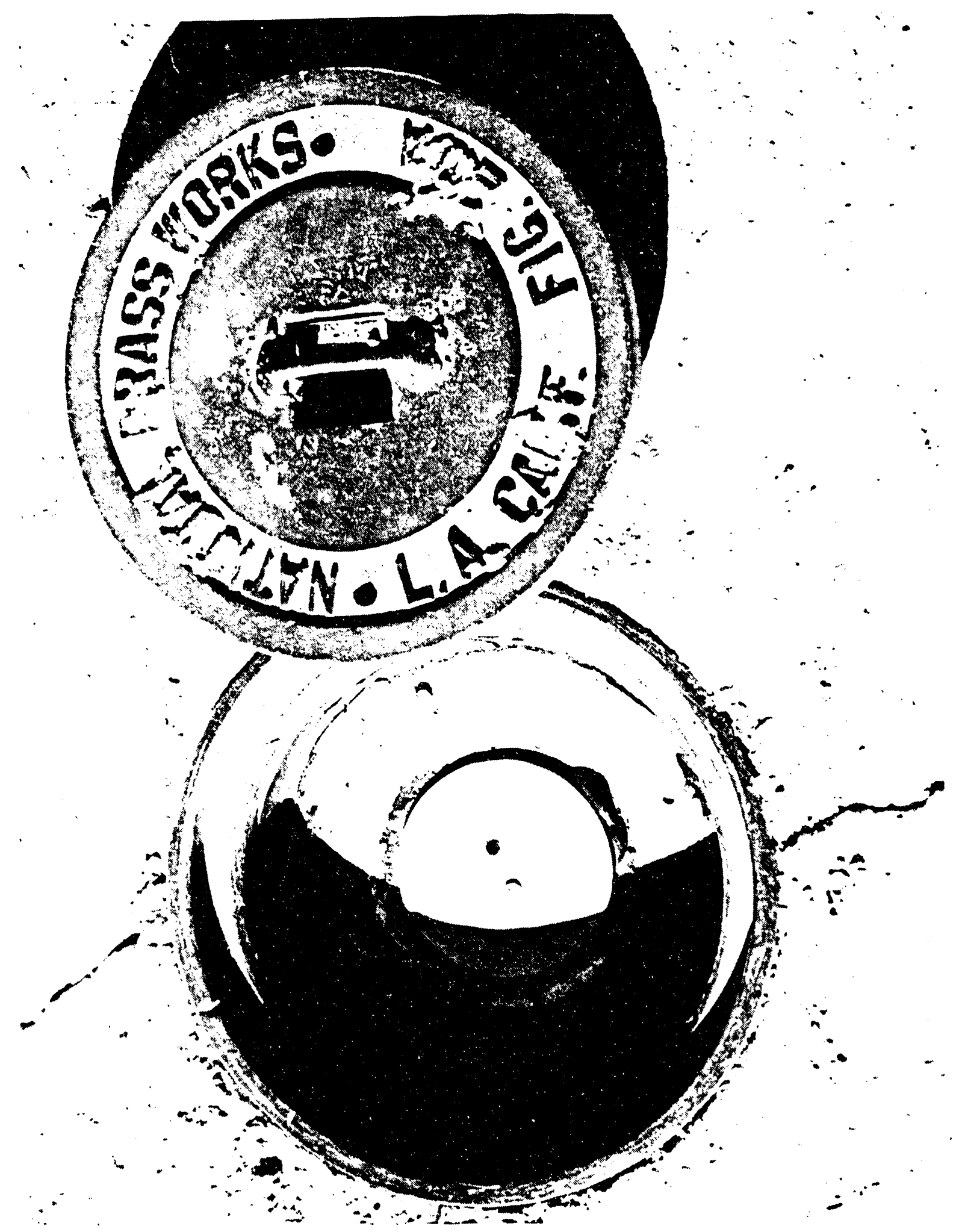

Figure 7. Access to a hydrant electrical connector. 


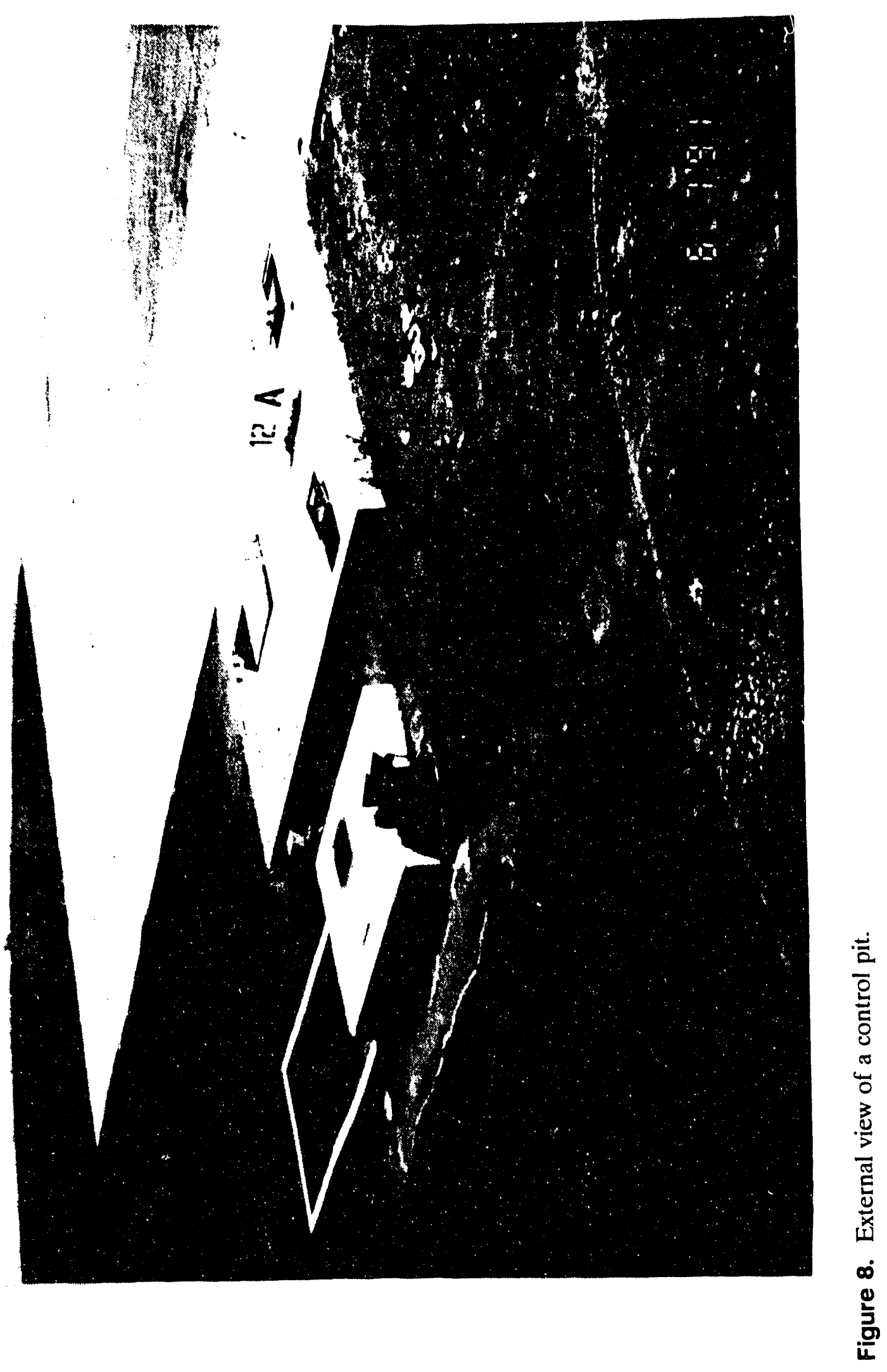




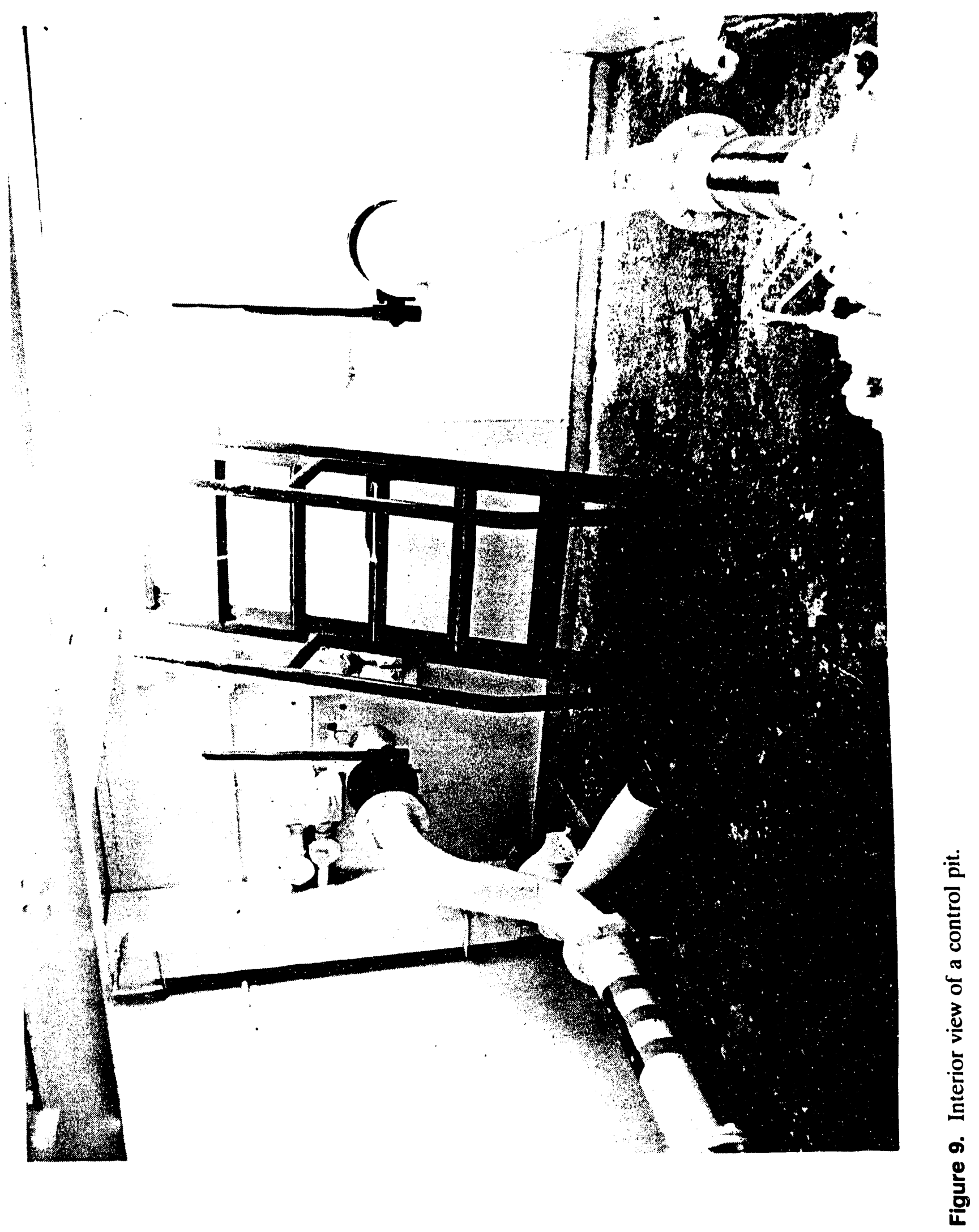




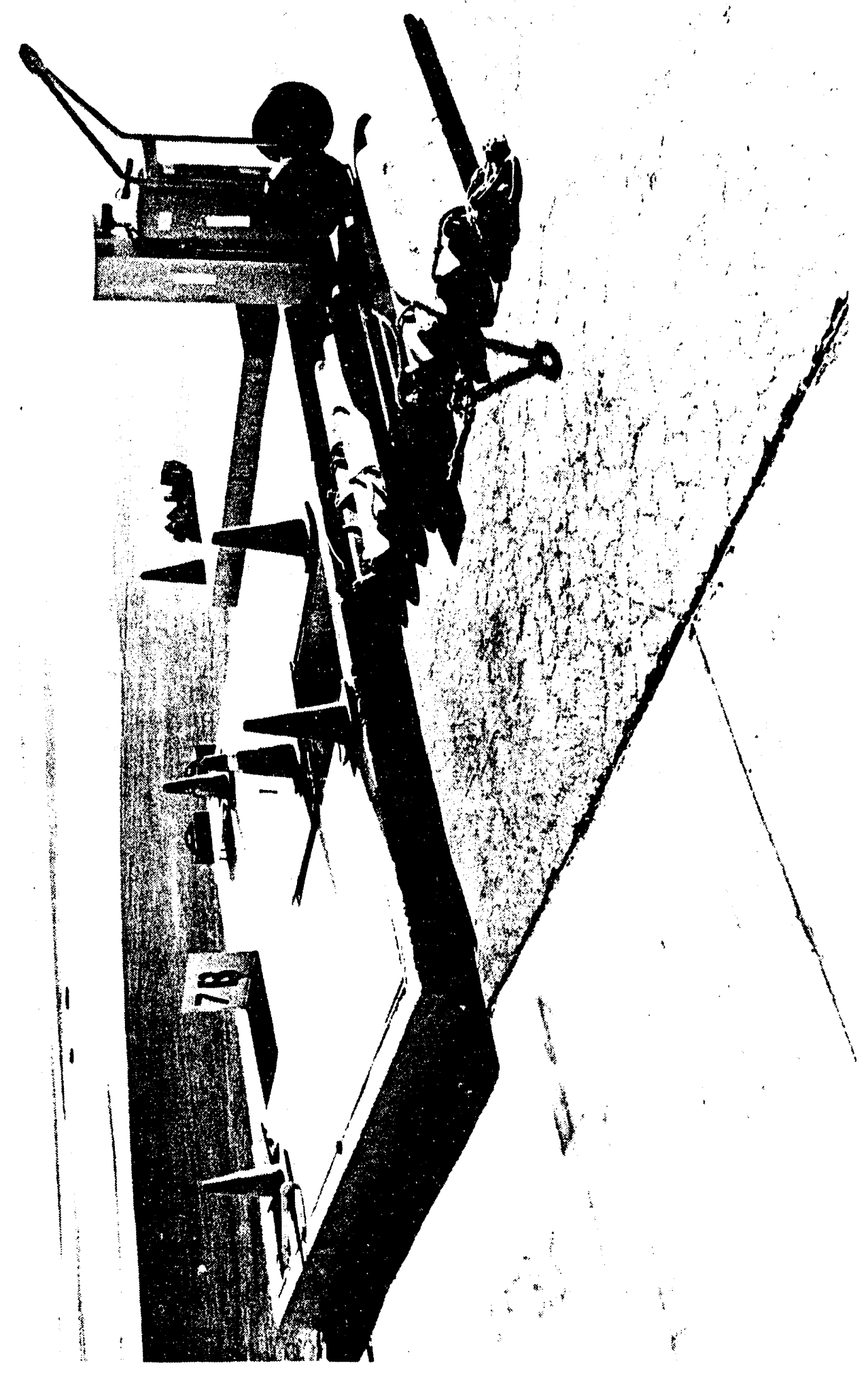

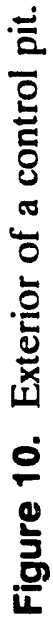




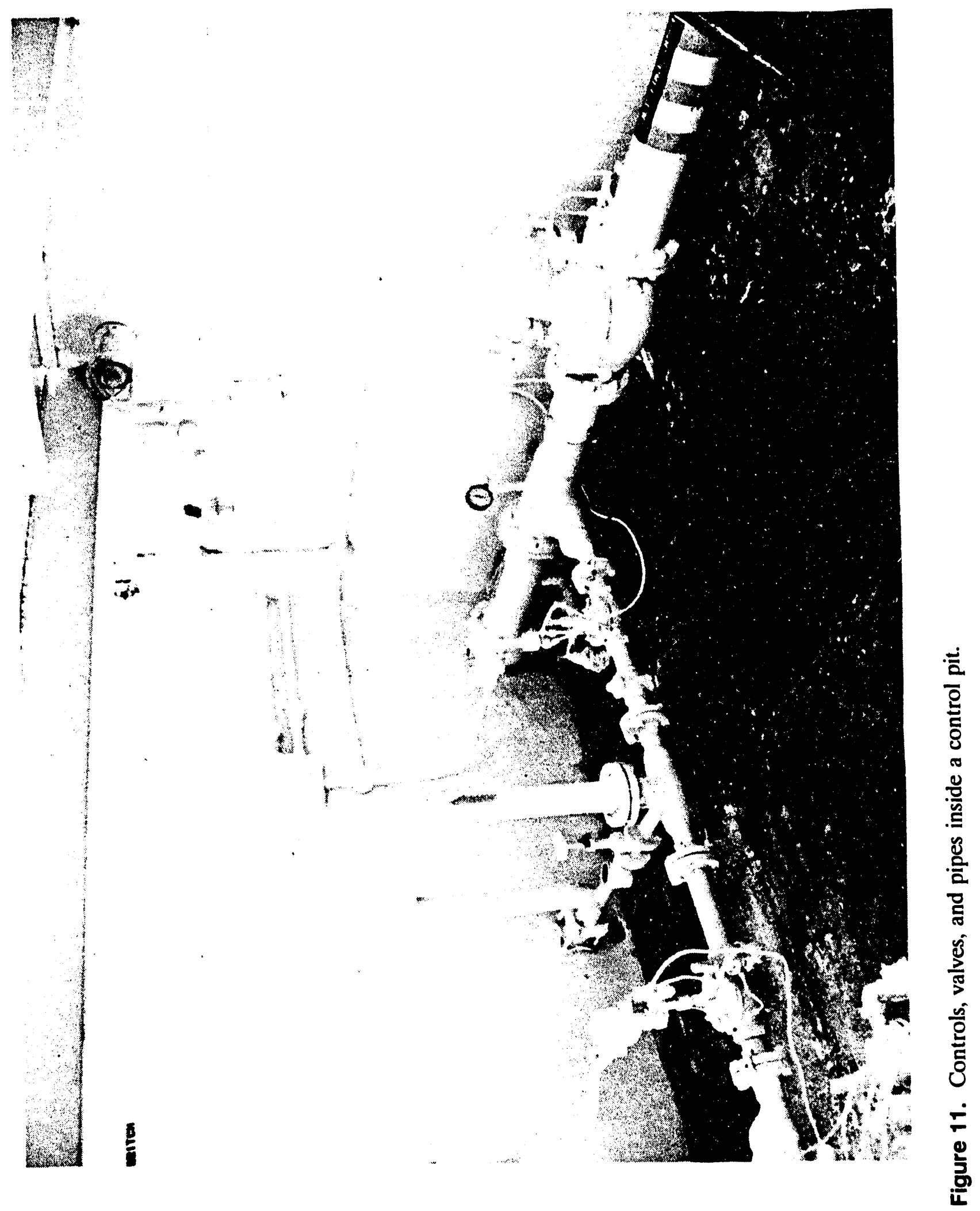




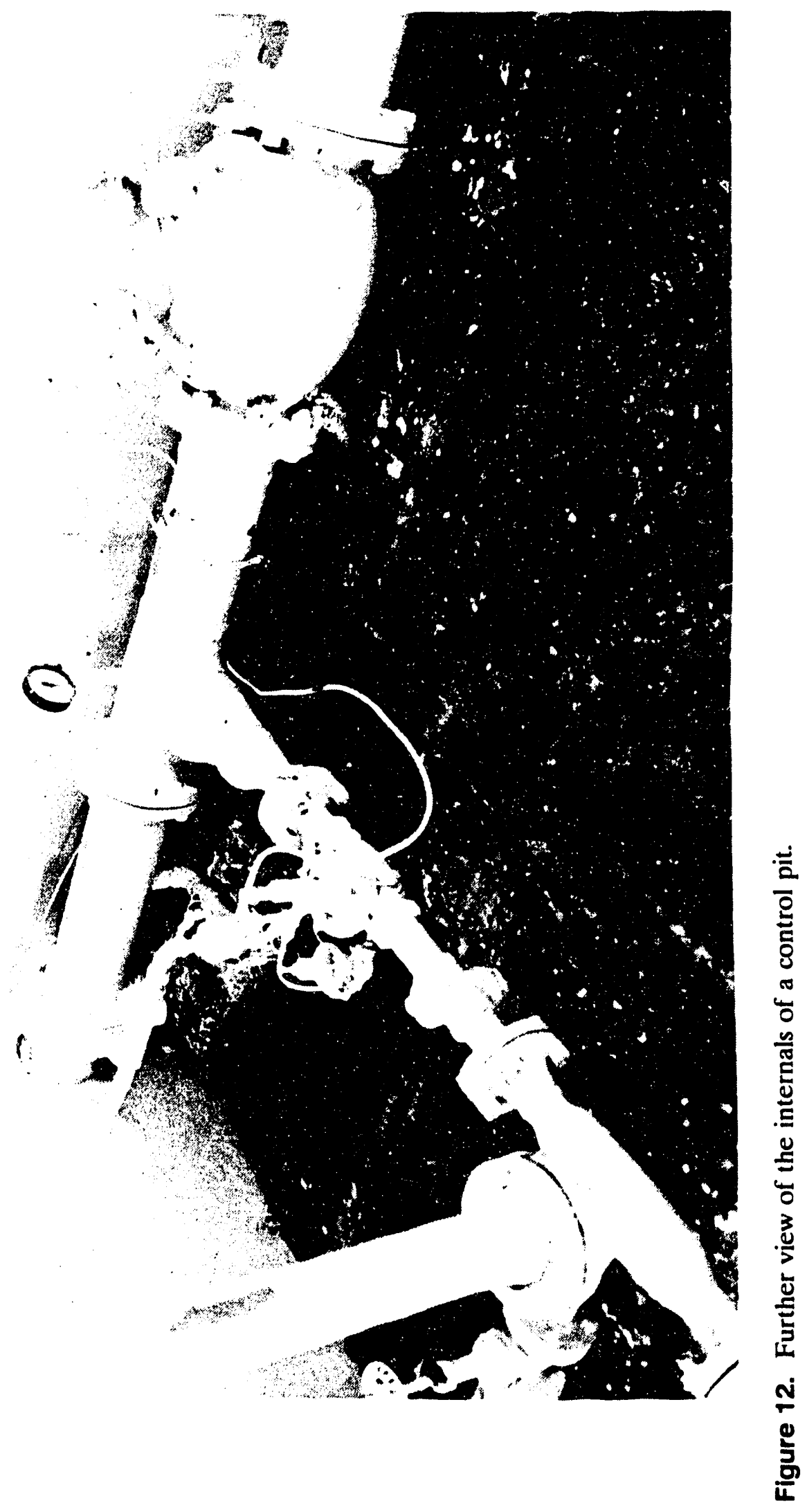




\subsection{Electrical Pull Box Removal}

Typical Electrical Pull Box configuration is shown in Figures 13 through 15.

- Remove Components-Remove the lid panels, electrical fixtures, electrical boxes, telephone, telephone junction box, and conduit inside the pull boxes.

- Pull Wire-Cut the wires in the next electrical pull box and pull the wiring from the piping.

- Remove Concrete-Remove the concrete structure for the electrical pull boxes adjacent to control pits 4,5 , and 6 .

- Replace Covers-Replace the covers of the electrical pull boxes adjacent to control pits 7 through 13.

\subsection{Control Building Removal}

The Control Building was between the east and west pump gallery. Figures 16 through 18 are internal views of the building.

- Remove Components-Remove the electrical fixtures, electric boxes, telephone, telephone junction box, stair railings, emergency shower, doors, windows, control panel, transformers, sink, emergency lights, control boxes, radiant heaters, lighting fixtures, and conduit.

- Remove the control building, including the foundation.

\subsection{Pump Gallery Removal}

The pump gallery is shown in Figures 19 through 22.

- Clean Tank-Tank contents shall be removed and the inside cleaned. Cleanliness will meet the requirements of the Riverside County Department of Health, Environmental Services Division, Underground Storage Tanks Section (April 1986), Riverside County Ordinance Number 617 dated April 1985, and Air Force requirements of Air Force Manual 85-16, Chapter 12. Certification from Riverside County may be required before proceeding with removal of the tank.

- Remove Components-Remove the electrical fixtures, electrical boxes, transformers, control boxes, lighting fixtures, valves, pumps, oil/water separators, piping, motors, underground tank access lids, and conduit.

- $\quad$ Remove the Pump Gallery-Remove the roof, floor, tanks, and tank supports and supporting members. 


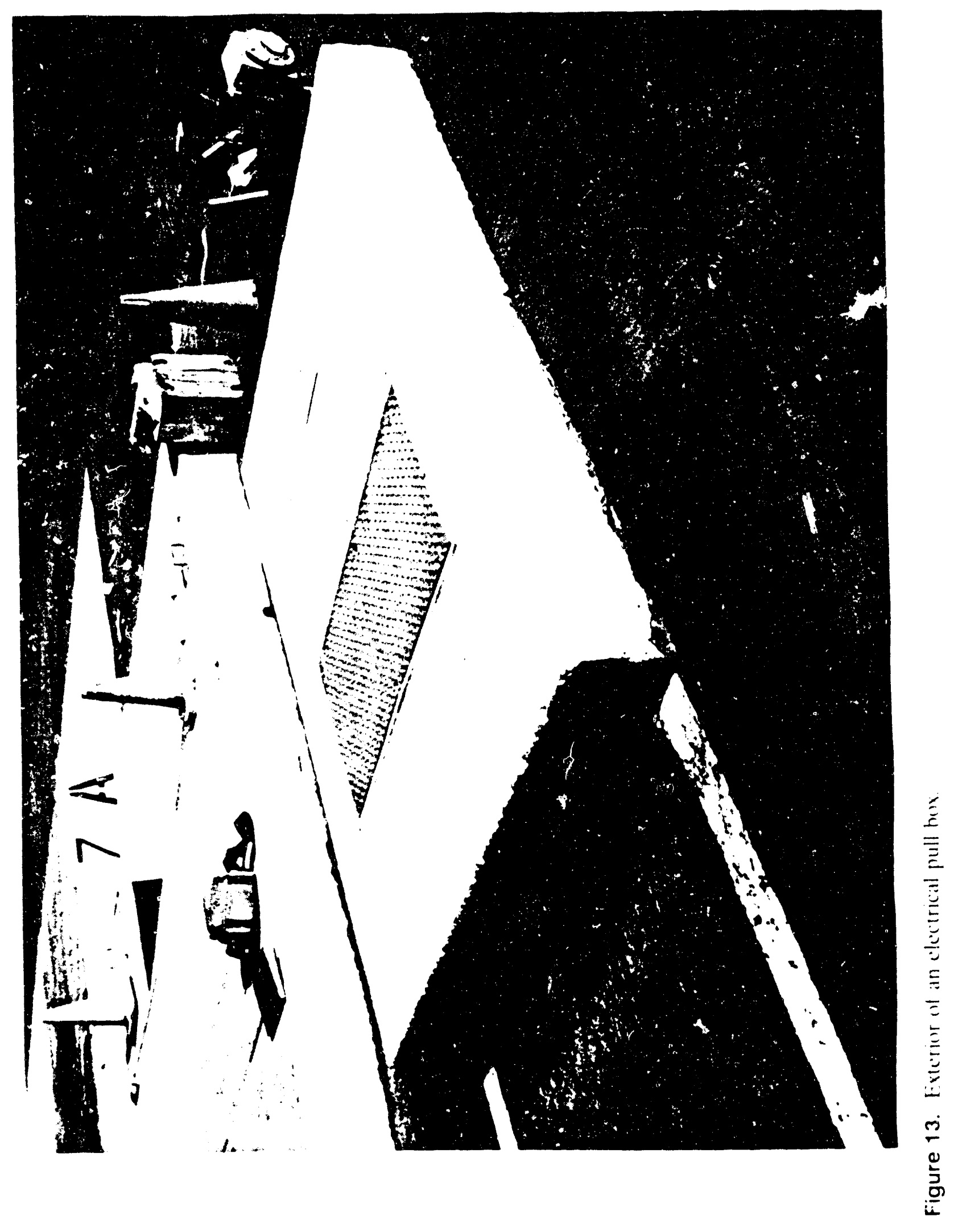




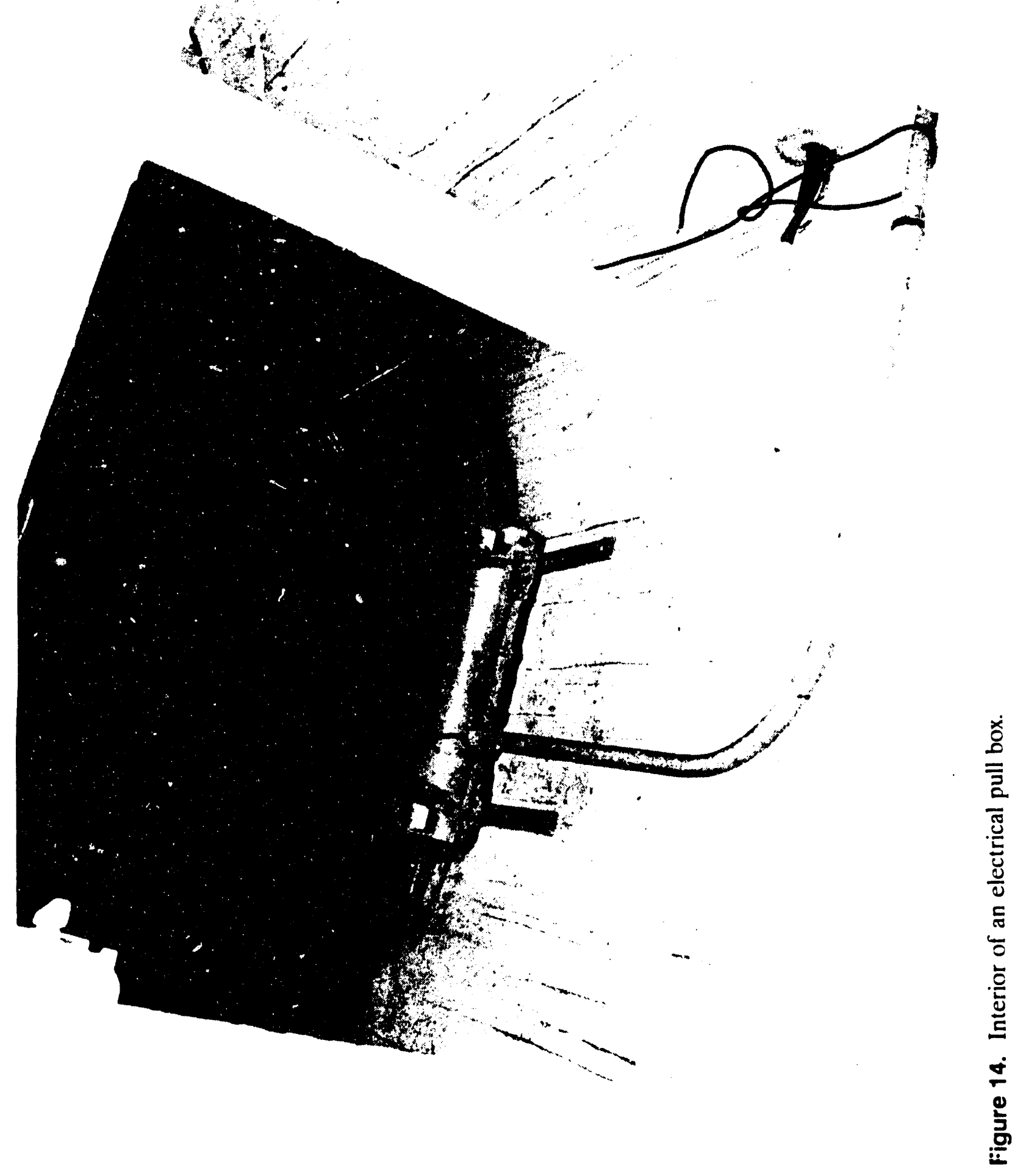




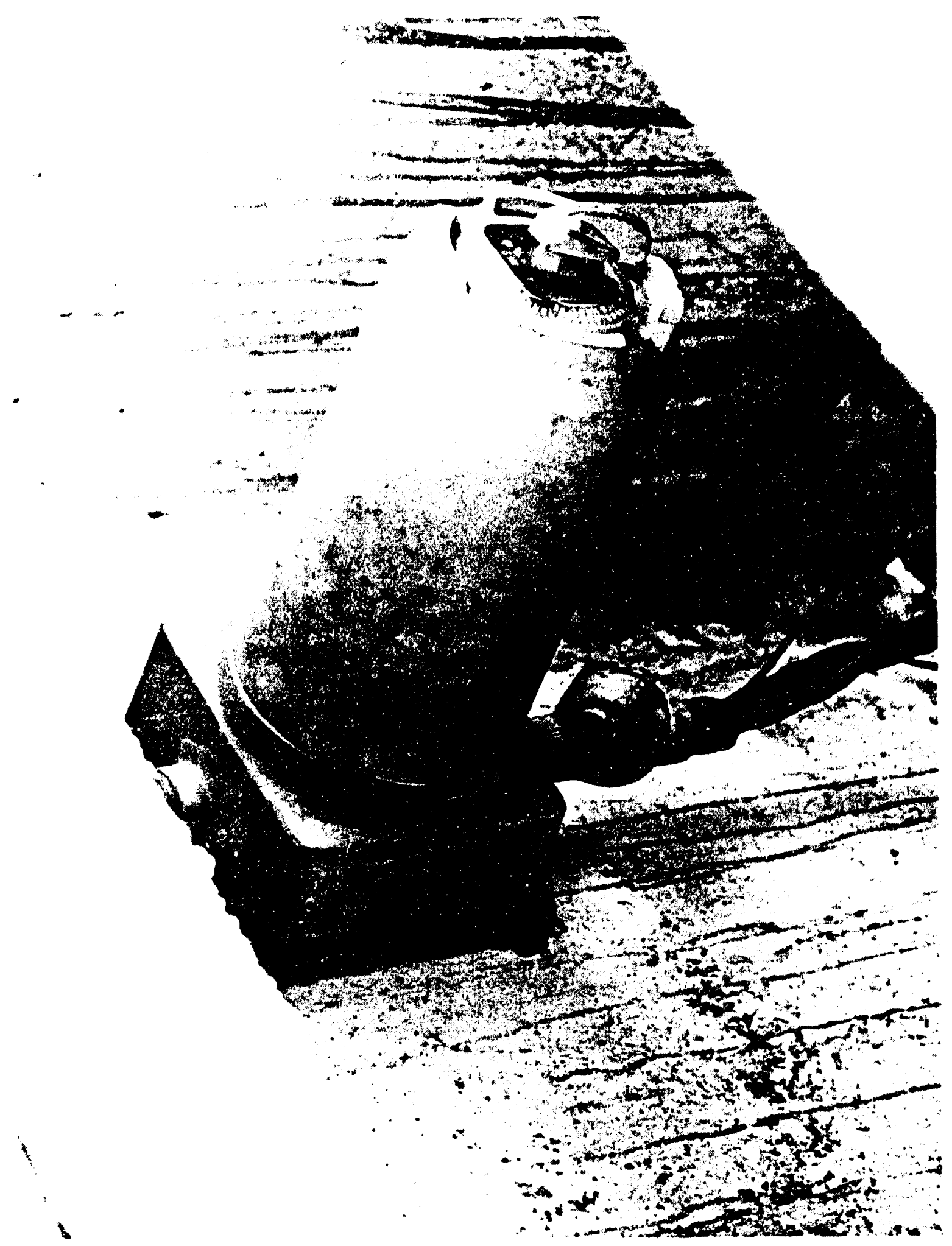

Figure 15. Interior of an electrical pull box. 


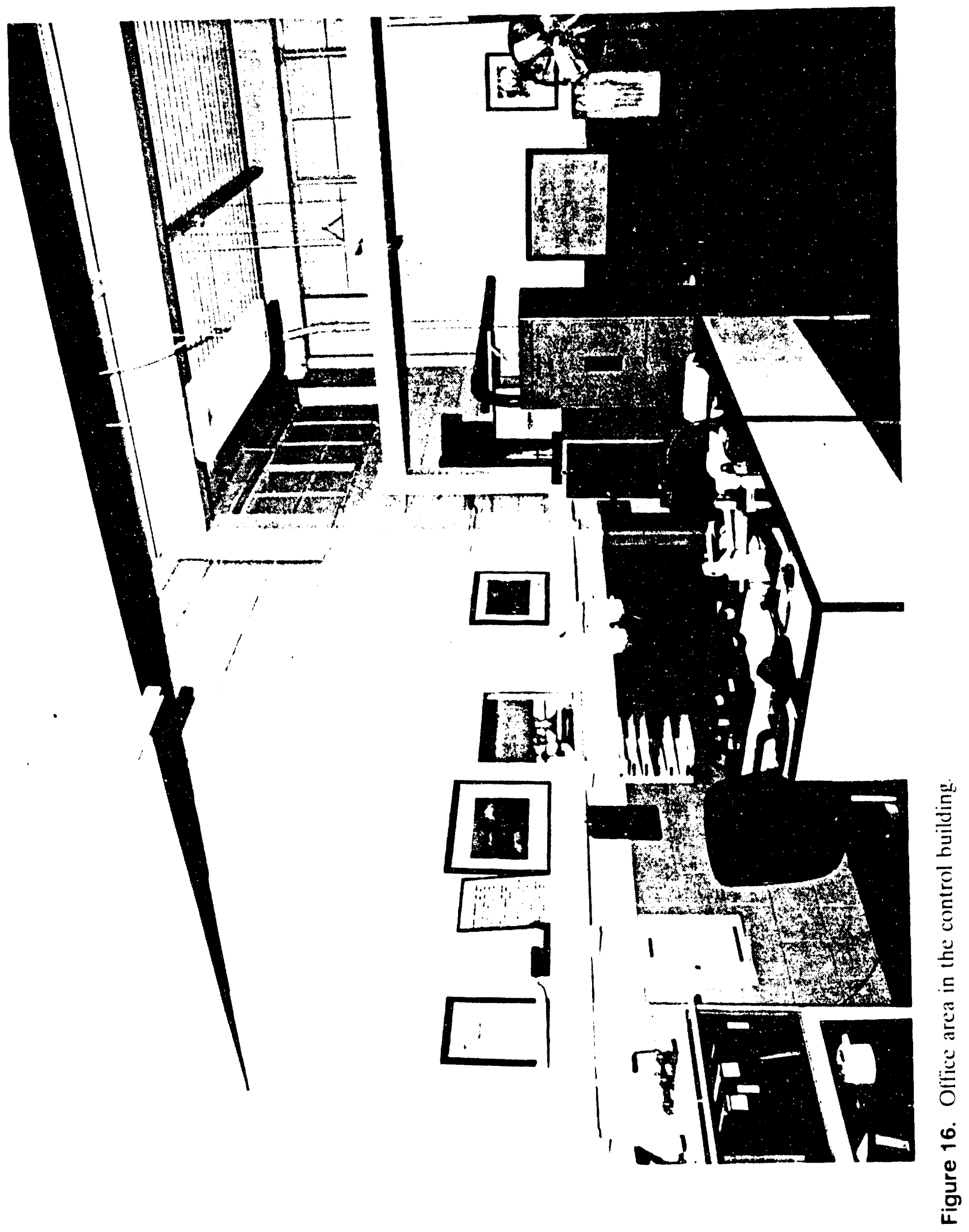




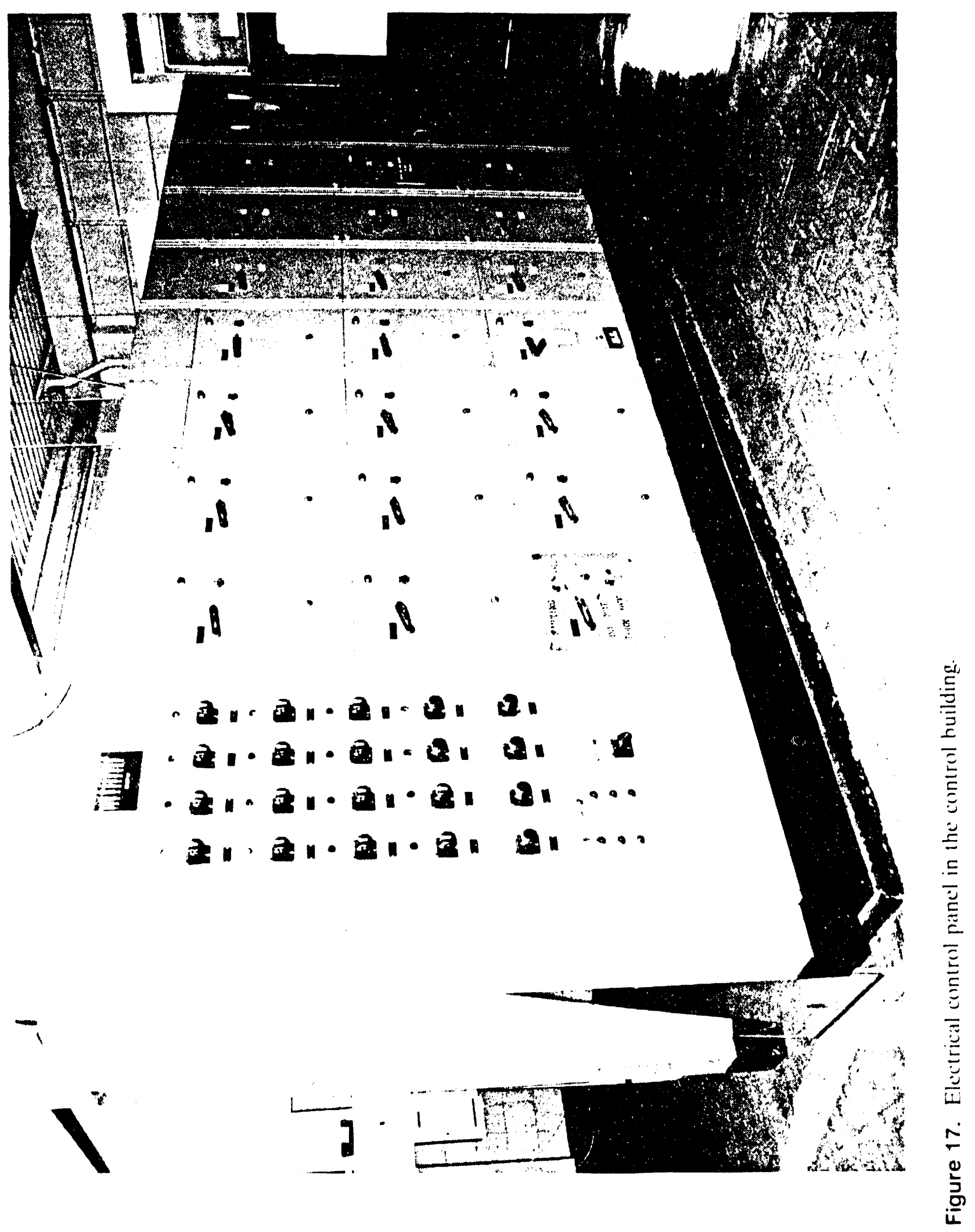




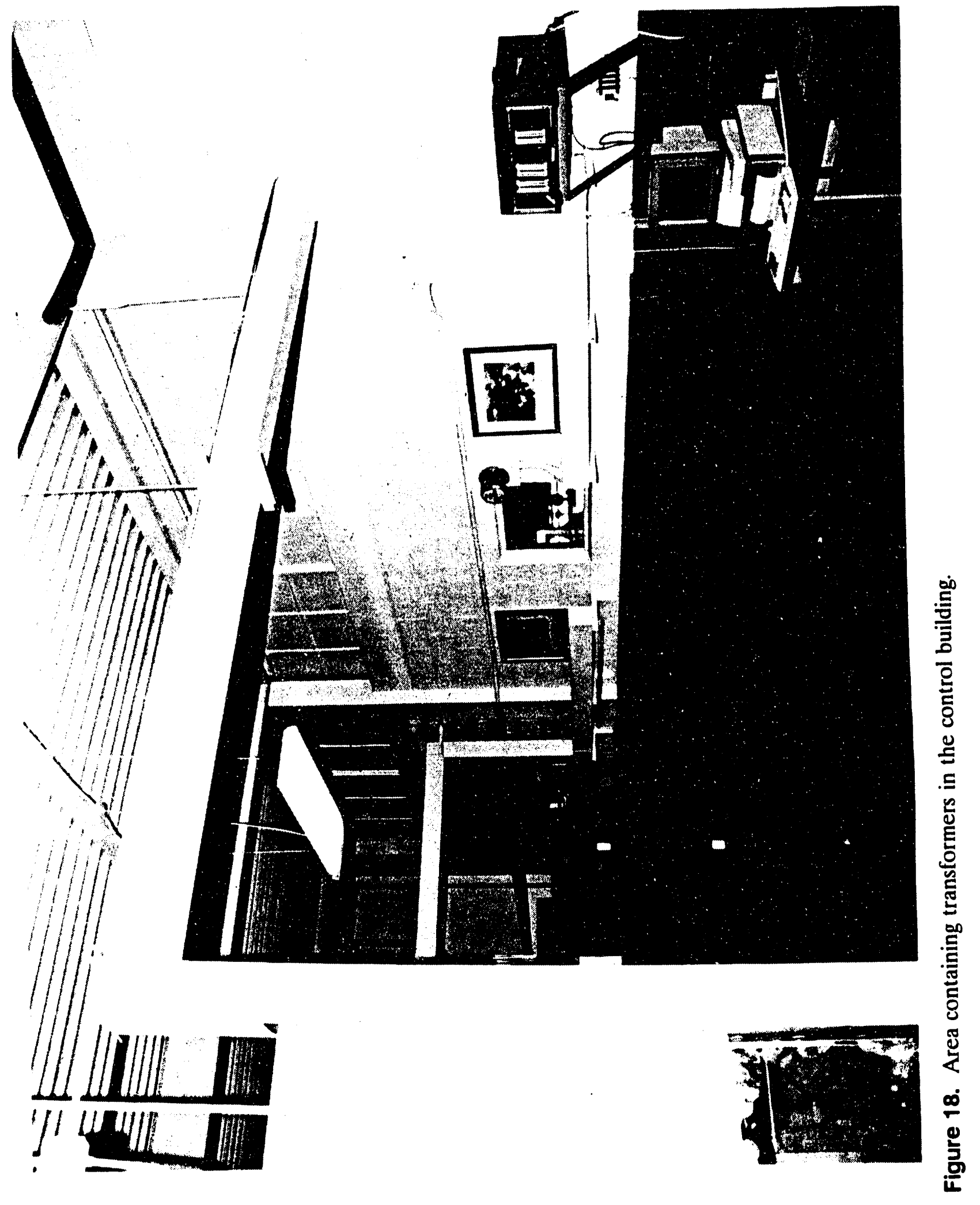




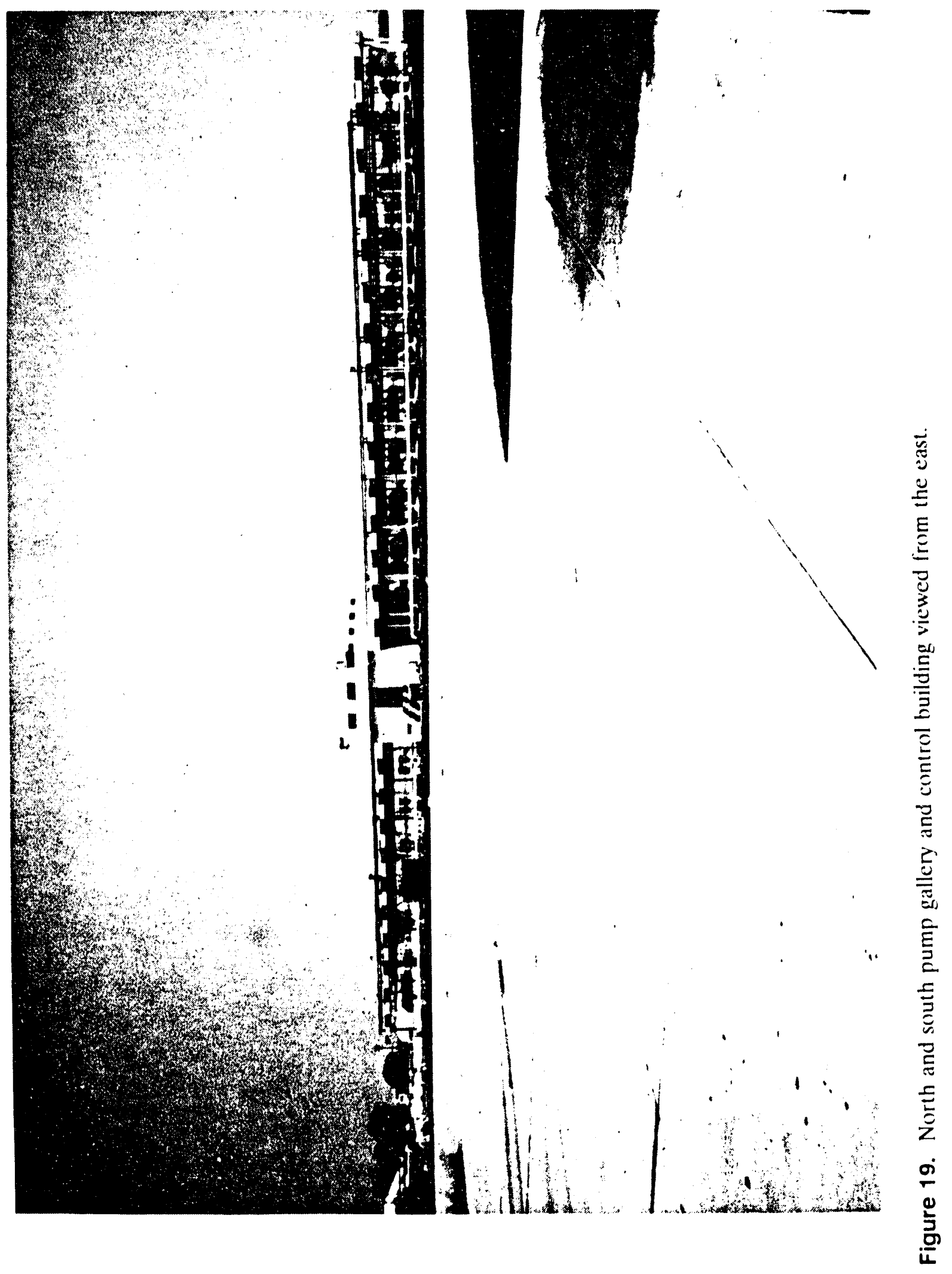




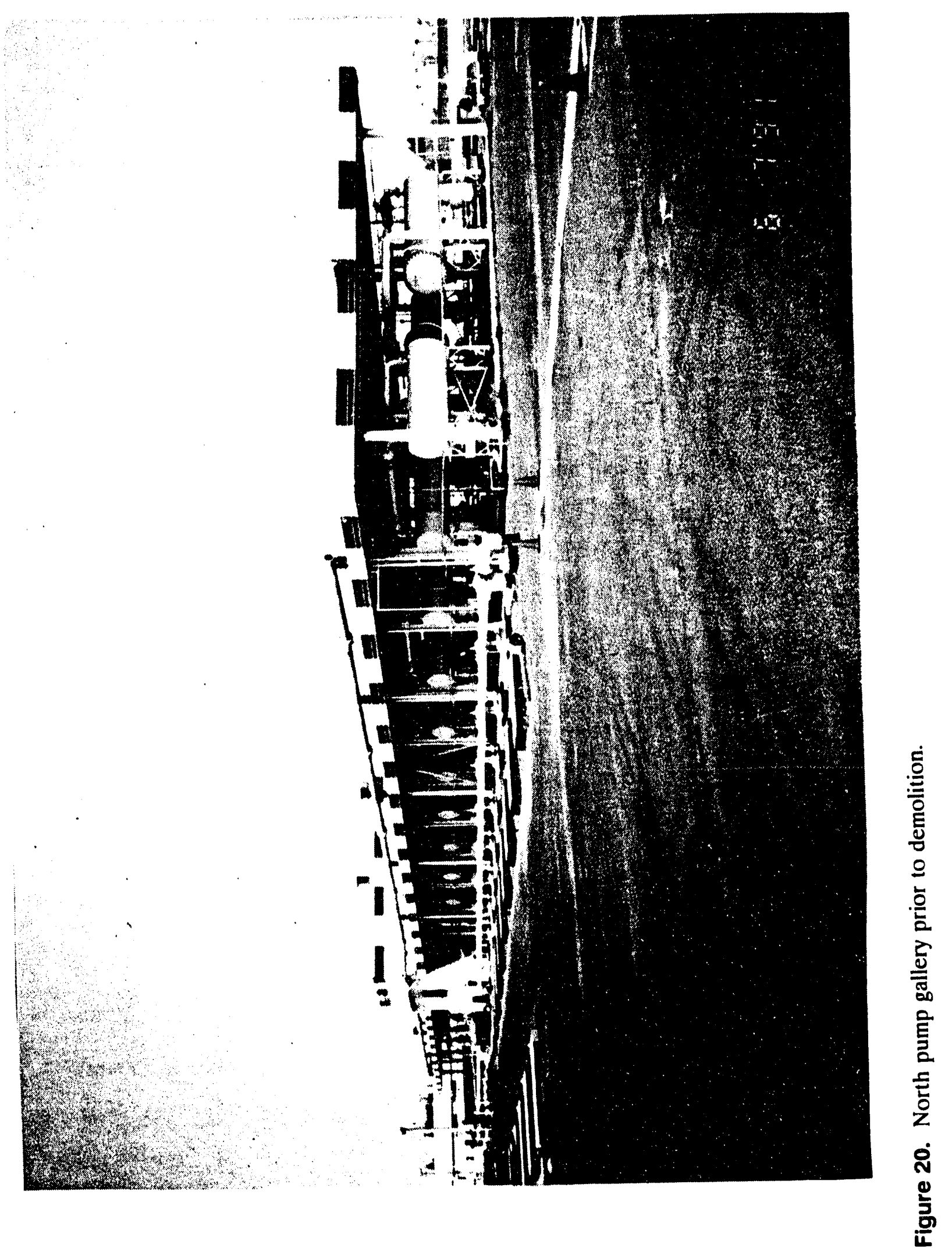




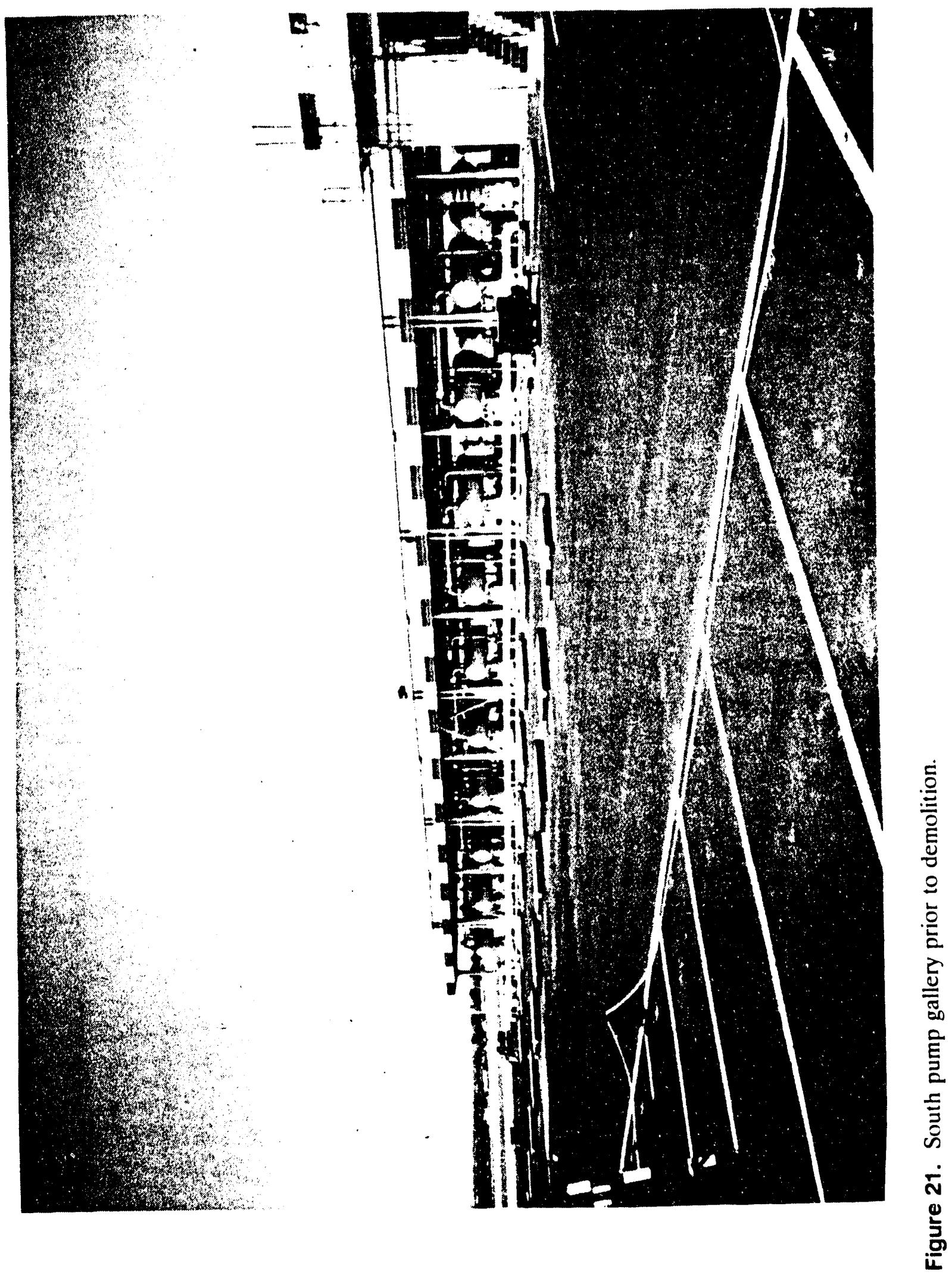




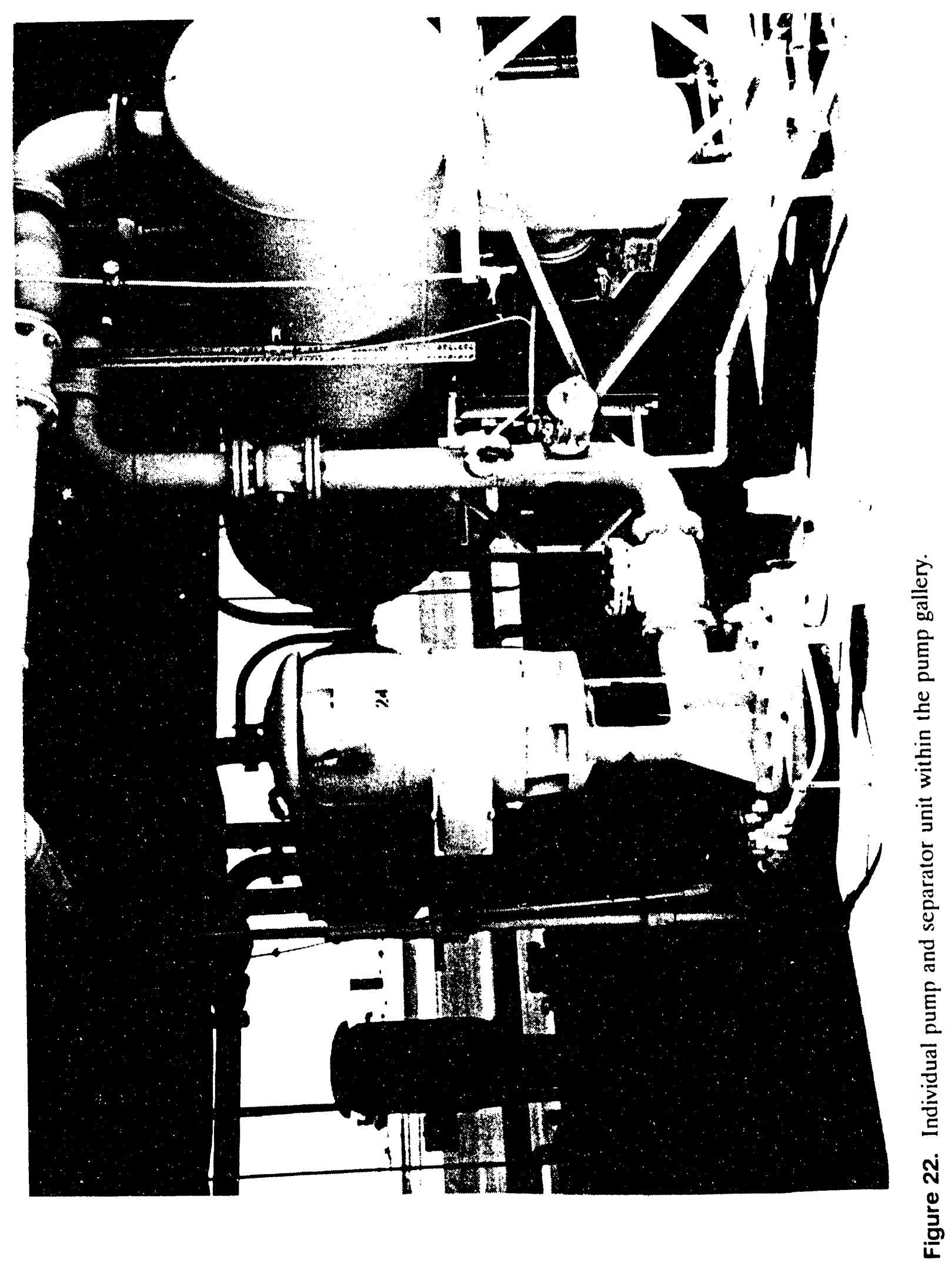




\subsection{Vapor Recovery Unit Removal}

The Vapor Recovery Unit is shown in Figure 23.

- Remove Components-Disconnect the 8-in. fuel vapor line at the Jamesbury valve. Disconnect electrical feeder at the $100 \mathrm{Amp}, 3$ s switch. Disconnect fuel lines to the tank gallery and to the adjacent underground storage tank. Dismantle the Vapor Recovery Unit and place on pallets. Remove the underground tank access lid.

- Clean Tank-Tank contents shall be removed and the inside cleaned. Cleanliness will meet the requirements of the Riversidc County Department of Health, Environmental Services Division, Underground Storage Tanks Section (April 1986), Riverside County Ordinance Number 617 dated April 1985, and Air Force requirements of Air Force Manual 85-16, Chapter 12. Certification from Riverside County may be required before proceeding with removal of the tank.

- $\quad$ Remove Tank-Remove the underground storage tank.

- $\quad$ Remove Lines-Excavate and remove the condensate return, vapor, and electrical lines between the Vapor Recovery Unit and the tank gallery.

- Remove Concrete-Remove the concrete structures associated with the Vapor Recovery System.

\subsection{Defueling Tank Removal}

The defueling tank and associated pipelines were underground. Tank access and controls are aboveground.

- Clean Tank-Tank contents shall be removed and the inside cleaned. Cleanliness will meet the requirements of the Riverside County Department of Health, Environmental Services Division, Underground Storage Tank.s Section (April 1986), Riverside County Ordinance Number 617 dated April 1985, and Air Force requirements of Air Force Manual 85-16, Chapter 12. Certification from Riverside County may be required before proceeding with removal of the tank.

- $\quad$ Remove Components-Remove the lid panels, piping, electrical fixtures, valves, floor drain grate, access ladder, and cover panel metal supports.

- Cut Piping-Excavate and cut the fucl lines and sewer line and cap the sewer line at the excavation boundary. Excavation work for this tank shall not disturb any aircraft ramp concrete. 


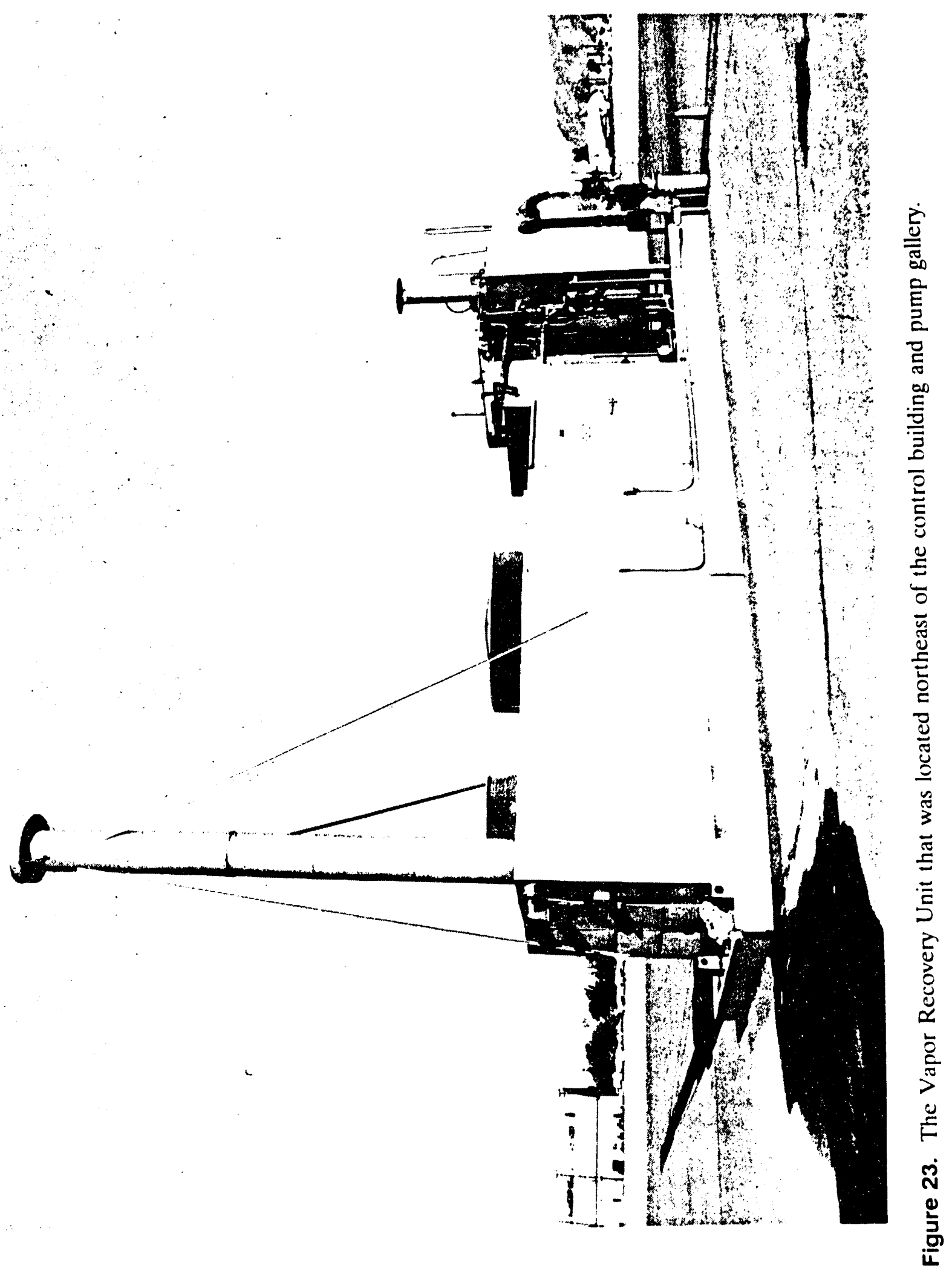


- Remove Concrete-Remove the concrete structure over the tank.

- Remove and Cut Tank-Remove the underground storage tank and dispose.

\subsection{Underground Piping Removal and Abandonment}

- Remove Concrete and Asphalt-Remove the concrete and asphalt over the piping between the main facility and control pits 4,5 , and 6 . No piping shall be removed beyond the edge of the asphalt surrounding the control facility in the direction of control pit 7.

- Remove Fuel and Vapors-Remove all remaining fuel, fuel vapors, and other liquid from the lines to be abandoned in-place. These lines are from the limit of the excavation of the pump gallery to control pits 7 through 13 , the lines from the hydrants to control pits 7 through 13, and other fuel lines associated with control pit 7 through 13.

- $\quad$ Remove Piping-Remove the underground piping for control pits 4, 5, and 6 and dispose.

- Inert Material-Fill the lines abandoned in-place with a closed-cell urethane foam. The Contracting Officer shall approve the closed-cell urethane foam and the procedure for employing the foam 14 days prior to use.

- Cut and Cap-All lines from the main facility to be filled with closed-cell urethane foam will be cut at the limit of excavation and capped. All other lines will be capped where the lines enter the structure.

\subsection{Backfill and Compaction}

- Fill to Grade-Fill the cavities left by the removal of the Aircraft Fuel Hydrant System with soil.

- Soil Binder Application-All areas that are brought to grade will have a soil binder mixed with the last lift of soil. This soil binder will prevent the top soil from migrating regardless of the weather conditions for one year. 


\section{DEMOLITION RESULTS}

This section will document with narrative and photographs the results of the work to remove the Aircraft Fueling Hydrant System.

Removal of the Panero refueling system began in May 1991, and was completed in March 1992. Universal Engineering Inc. was contracted by March Air Force Base to perform the system removal. Chemical Waste Inc. of Denver was responsible for the analysis of excavated soil, and Ryan-Murphy Inc. was responsible for treatment of all contaminated soil.

\subsection{Transformer and Rectifier Analysis}

A small amount of coolant was removed from (a) the two transformers located in the Control Room of the Control Building, (b) the two rectifiers on the west side of the Control Room Building, and (c) one transformer in the west side panel of the Vapor Recovery Unit. The sample material was sent to an analytical laboratory for chemical analysis for PCBs, and none were detected in any of the samples.

\subsection{Hydrants and Piping}

The following elements were completed on the hydrant pits.

\subsubsection{Hydrants for Pits 4, 5, and 6}

- Fuel supply lines were emptied and cleaned.

- The pipcline material and components, pit covers and supports, concrete flooring and containments pieces, and paving were removed and deposited at a State of California approved landfill.

- The salvageable material or equipment was sent to the Defense and Reutilization Marketing Office.

\subsubsection{Hydrants for Pits 7 through 13}

- Fuel supply lines were emptied and cleaned.

- Line material and components were removed and deposited at a State of California approved landfill.

- Pit covers and supports were not removed.

- The salvageable material or equipment was sent to the Defense and Reutilization Marketing Office. 


\subsection{Control Pit}

Figures 24 through 26 show typical work around the control pits and supply lines that fed them. The following elements were completed on the control pits.

\subsubsection{Control Pits 4, 5, and 6}

- $\quad$ Fuel supply lines were emptied and cleaned.

- The pipeline material and components were removed and deposited at a State of Ca i: ornia approved landfill.

- $\quad$ Pit covers and supports, concrete flooring and containments pieces, and paving was removed and deposited at a State of California approved landfill.

\subsubsection{Control Pits 7 through 13}

- $\quad$ Fuel supply lines (abo're and belowgrade) were emptied and cleaned.

- Line material and components were removed and deposited at a State of California approved landiill.

- $\quad$ Pit covers and supports were not removed.

\subsection{Electrical Pull Boxes}

The following elements were completed on the Electrical Pull Boxes. The transit pipes that contained asbestos were left in place. They were sealed to prevent the escape of the asbestos fibers.

\subsubsection{Electrical Pits 4,5 , and 6}

- The electrical and telephone components and wiring were removed from the pits.

- The pit covers and supports, concrete flooring and containme ats pieces, and paving were removed.

- The salvageable material and equipment were removed and shipped to the Defense and Reutilization Marketing Office. The remaining components were scrapped or deposited at a State ớ California approved landfill.

\subsubsection{Electrical Pits 7 through :3}

- The electrical and telephone components and wiring were removed from the pits and deposited at a State of California approved iandfill. 


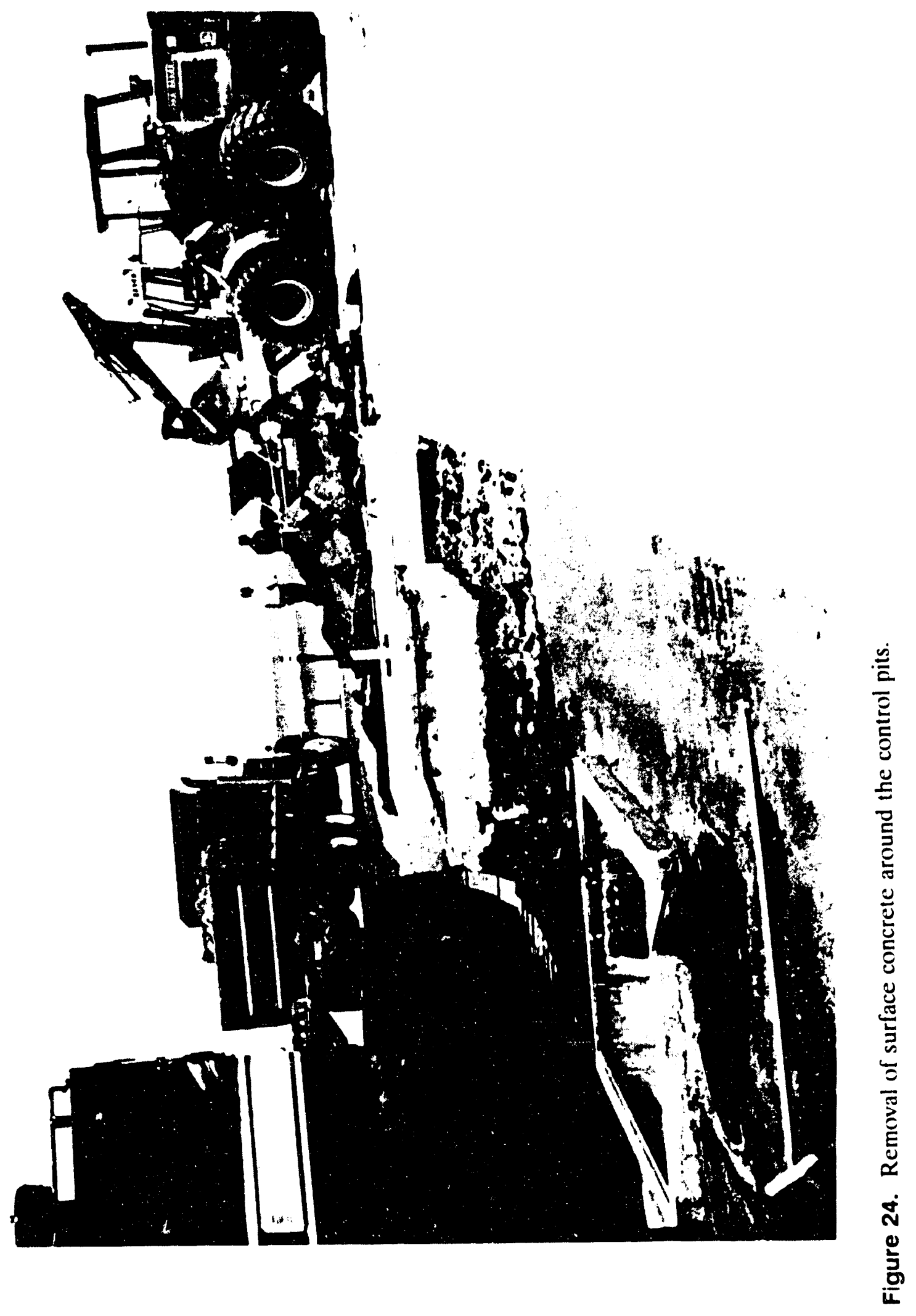




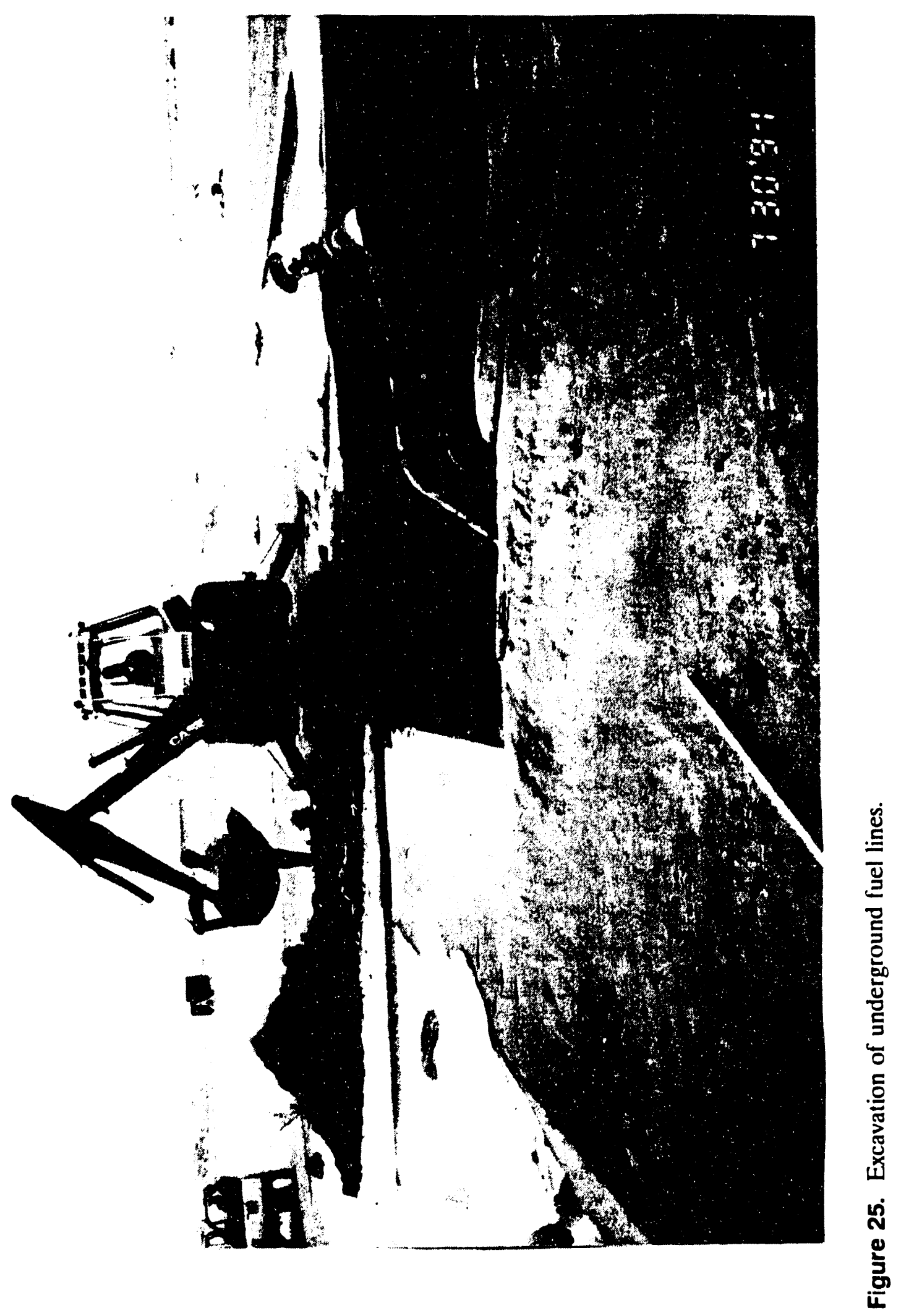




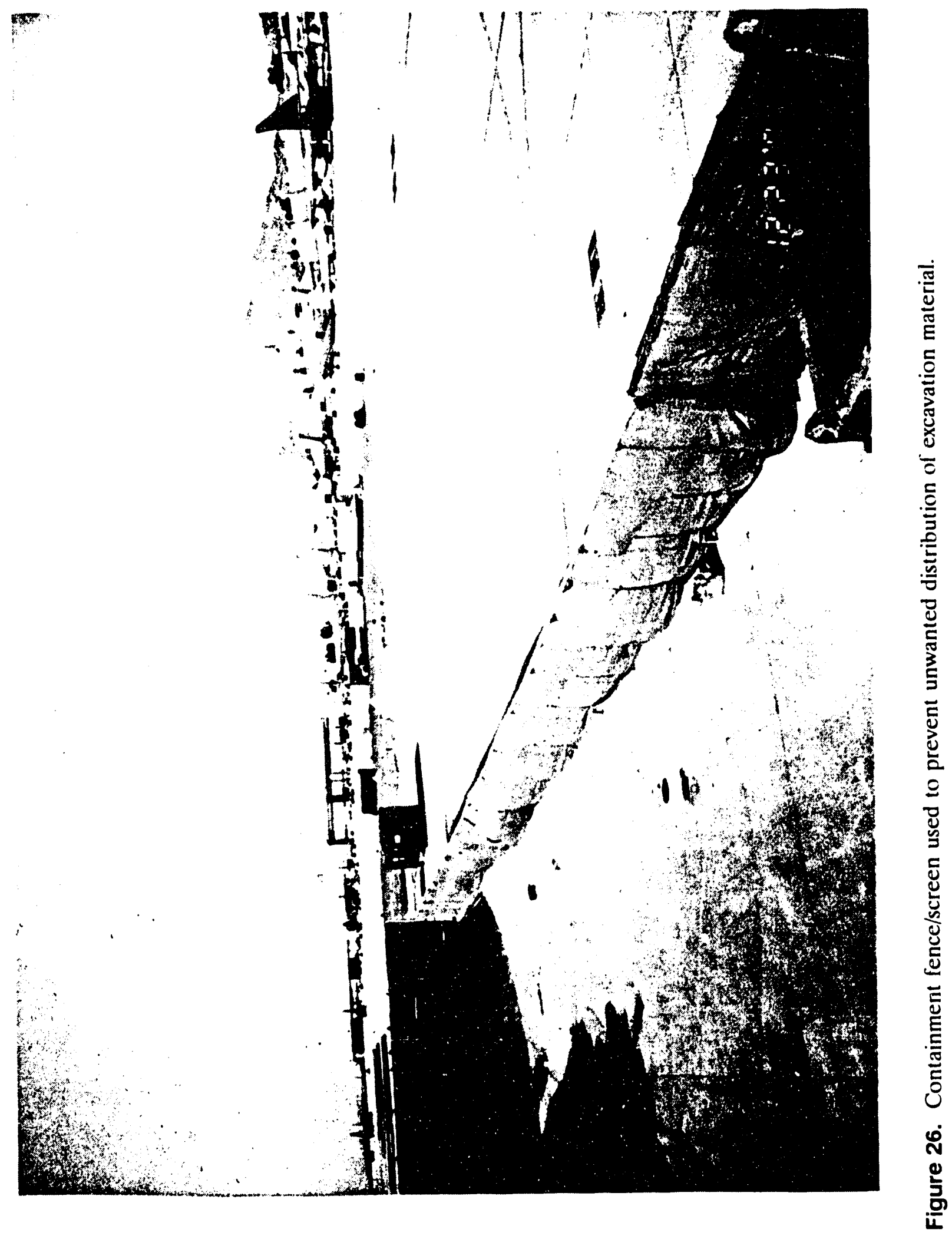


- The concrete pits were not removed.

- The salvageable material and equipment were removed and shipped to the Defense and Reutilization Marketing Office. The remaining components were scrapped or deposited at a State of California approved landfill.

Figures 27 and 28 show removal of some of the clectrical pit components.

\subsection{Control Building}

Figures 29 through 32 show demolition of the Control Building.

- The ashestos floor tile and adhesive were removed and discarded as a hazardous material at a State of California approved landfill.

- The salvageable material and equipment were removed and shipped to the Defense and Reutilization Marketing Office. The remaining components were scrapped and deposited at a State of California approved landfill.

\subsection{Pump Gallery}

Figures 33 through 42 show various stages and steps required in the demolition of the pump gallery.

- The salvageable material and equipments was removed, placed on pallets, and shipped to the Defense and Reutilization Marketing Office. The remaining components were scrapped or deposited at a State of California approved landfill.

- The roof system and concrete floors were removed and deposited at a State of California approved landfill.

- The 34 50,000-gal underground storage tanks were cleaned and exhumed. They were removed from March Air Force Base.

\subsection{Vapor Recovery Unit}

- The 550-gal tank was emptied, cleaned, and removed from March AFB.

- The Vapor Recovery Unit was disconnected from the fuel vapor line and all utilities. It was disassembled, placed on pallets or other platforms, and moved to a temporary storage location on the west side of Building 2506 at March AFB.

- The external piping associated with the Vapor Recovery Unit and the concrete foundation was excavated, removed, and deposited at a State of California approved landfill. 


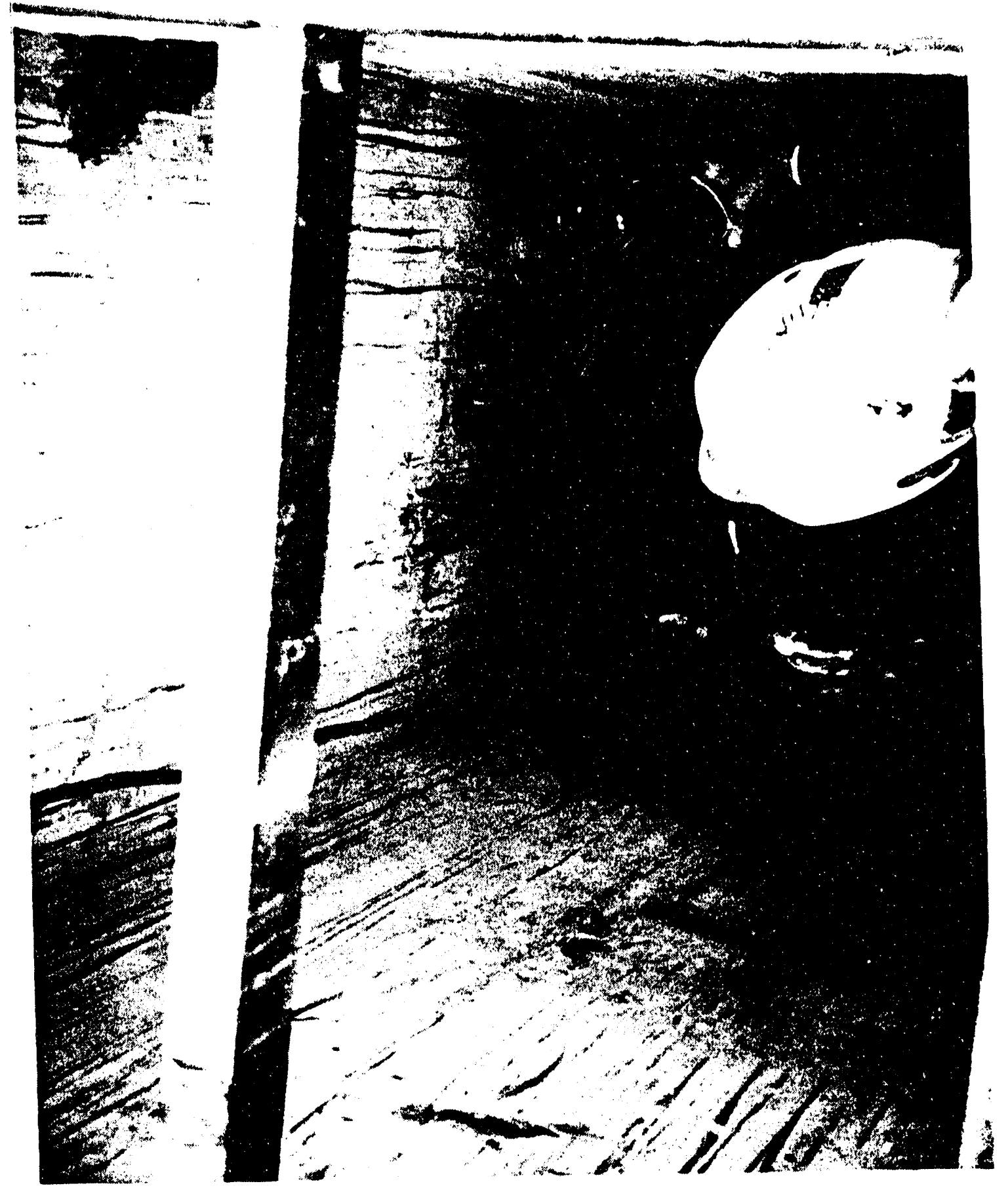

Figure 27. Demonstration of attaching the pull cable to the electrical wiring for removal. 

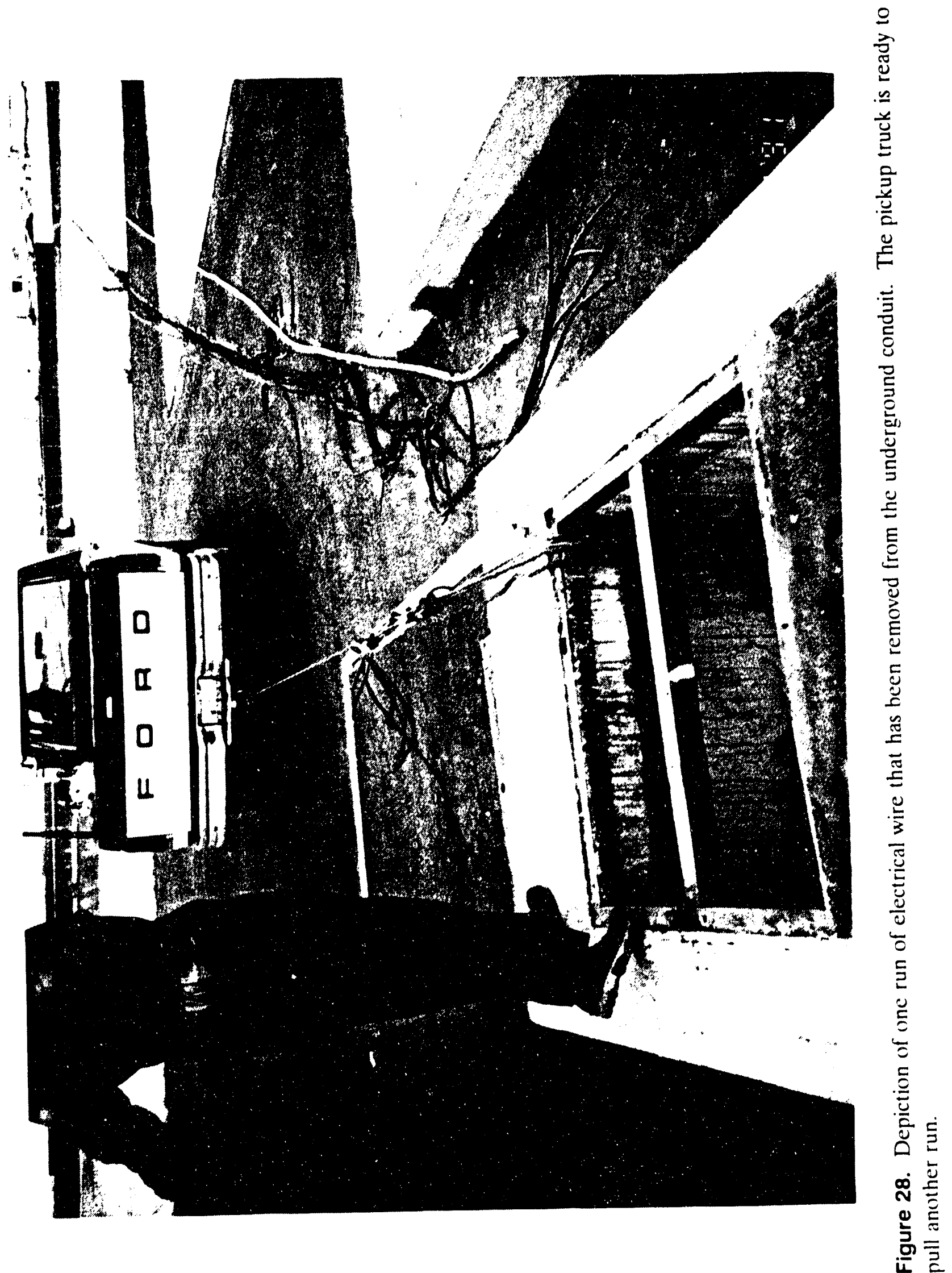


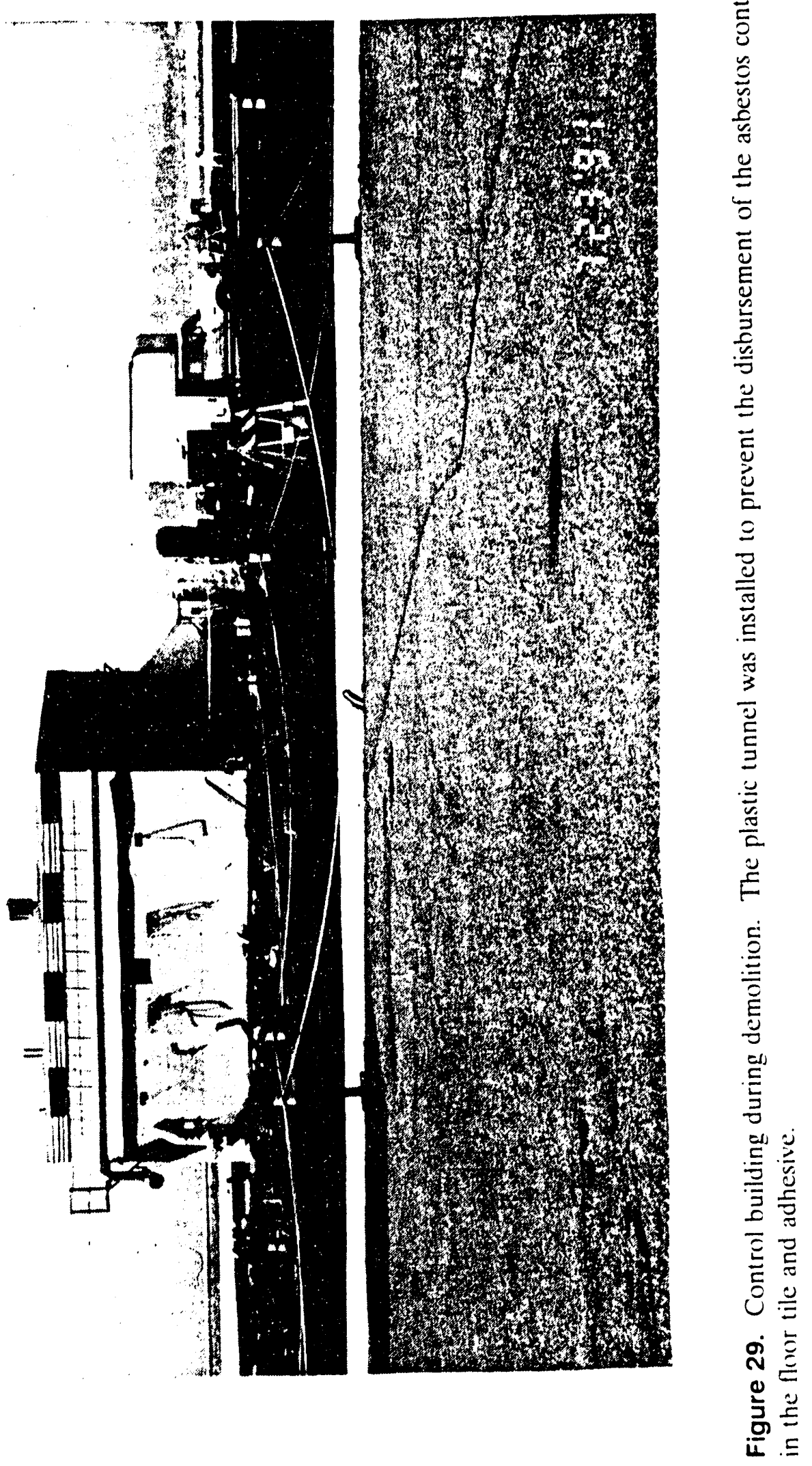




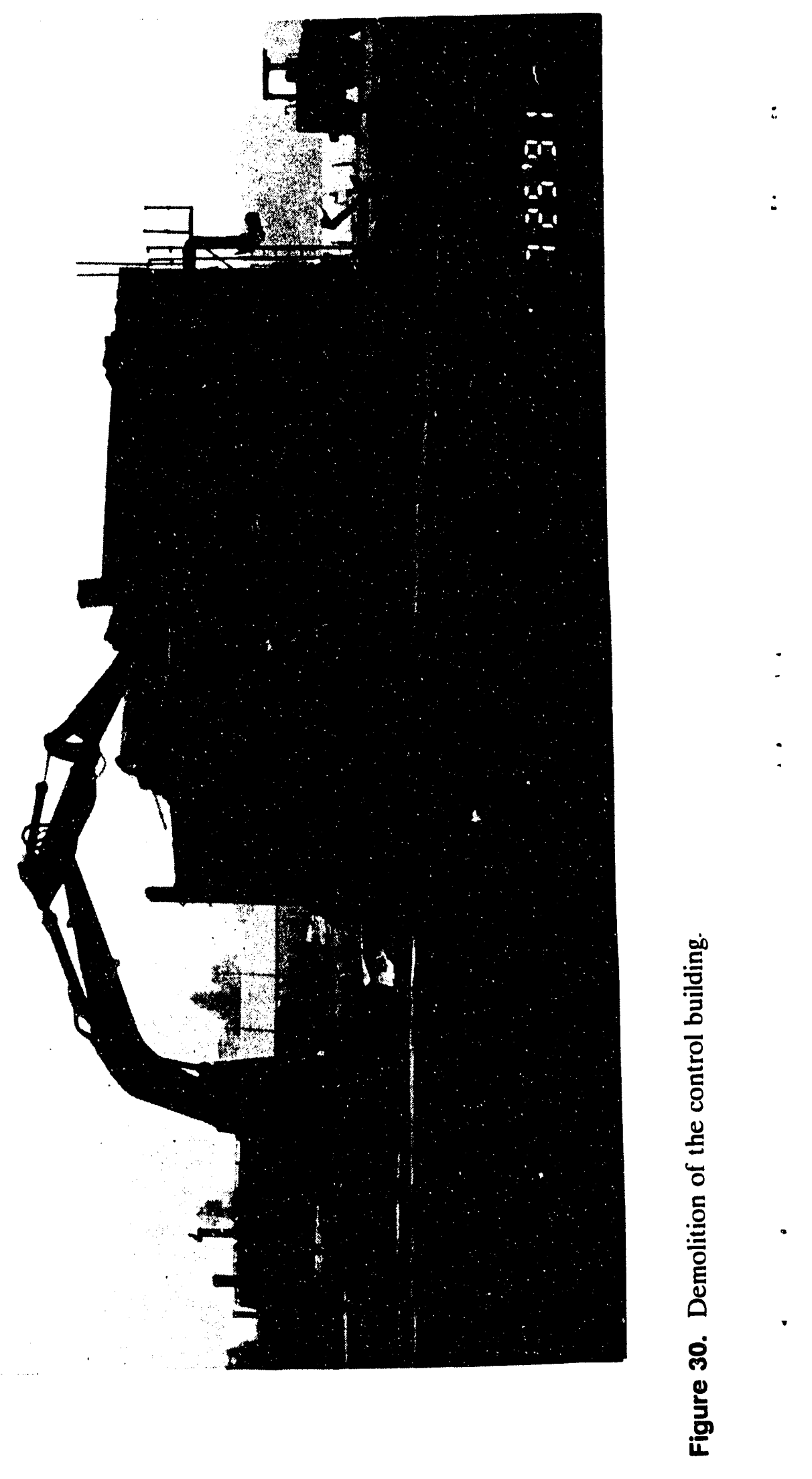




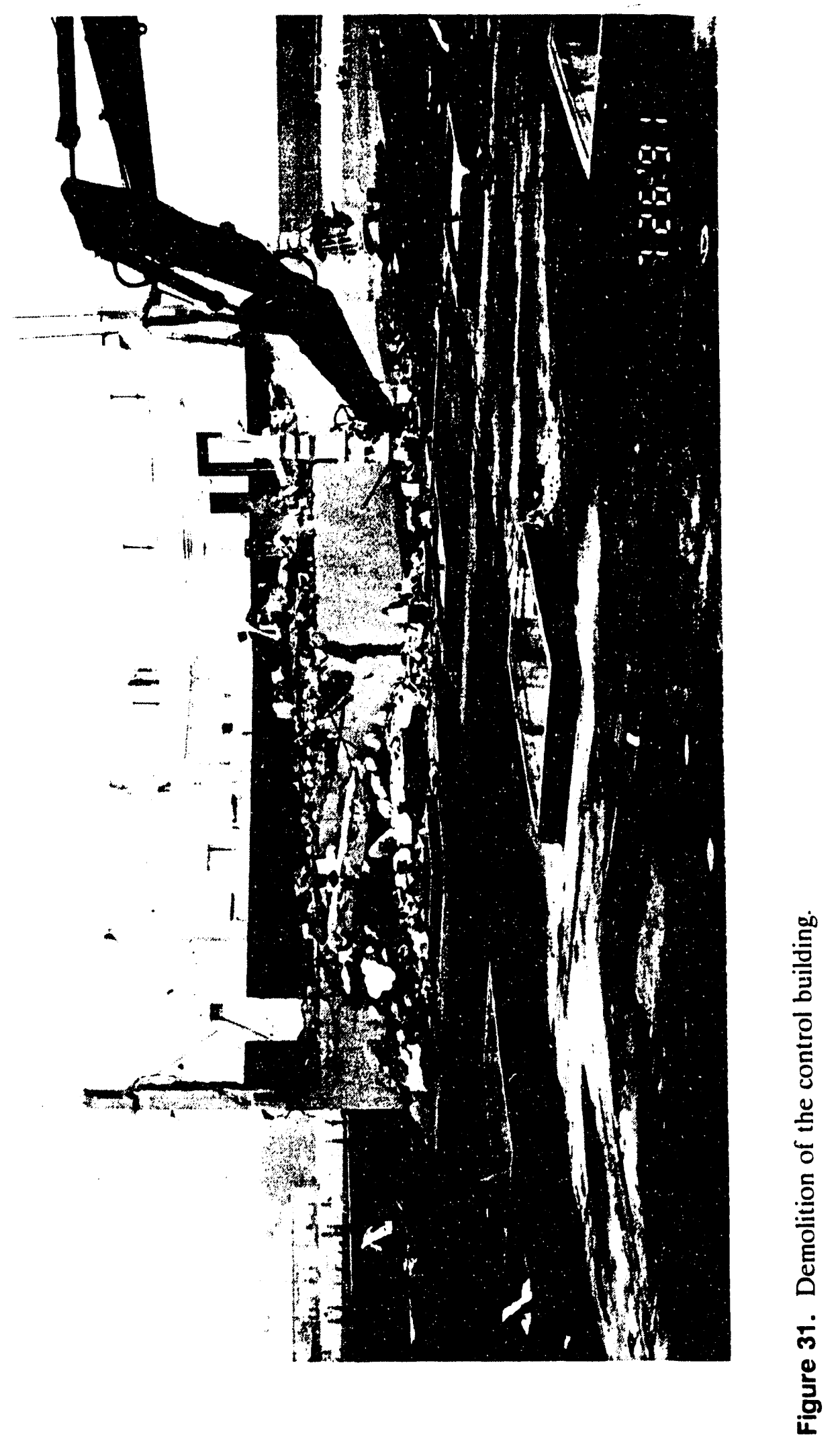




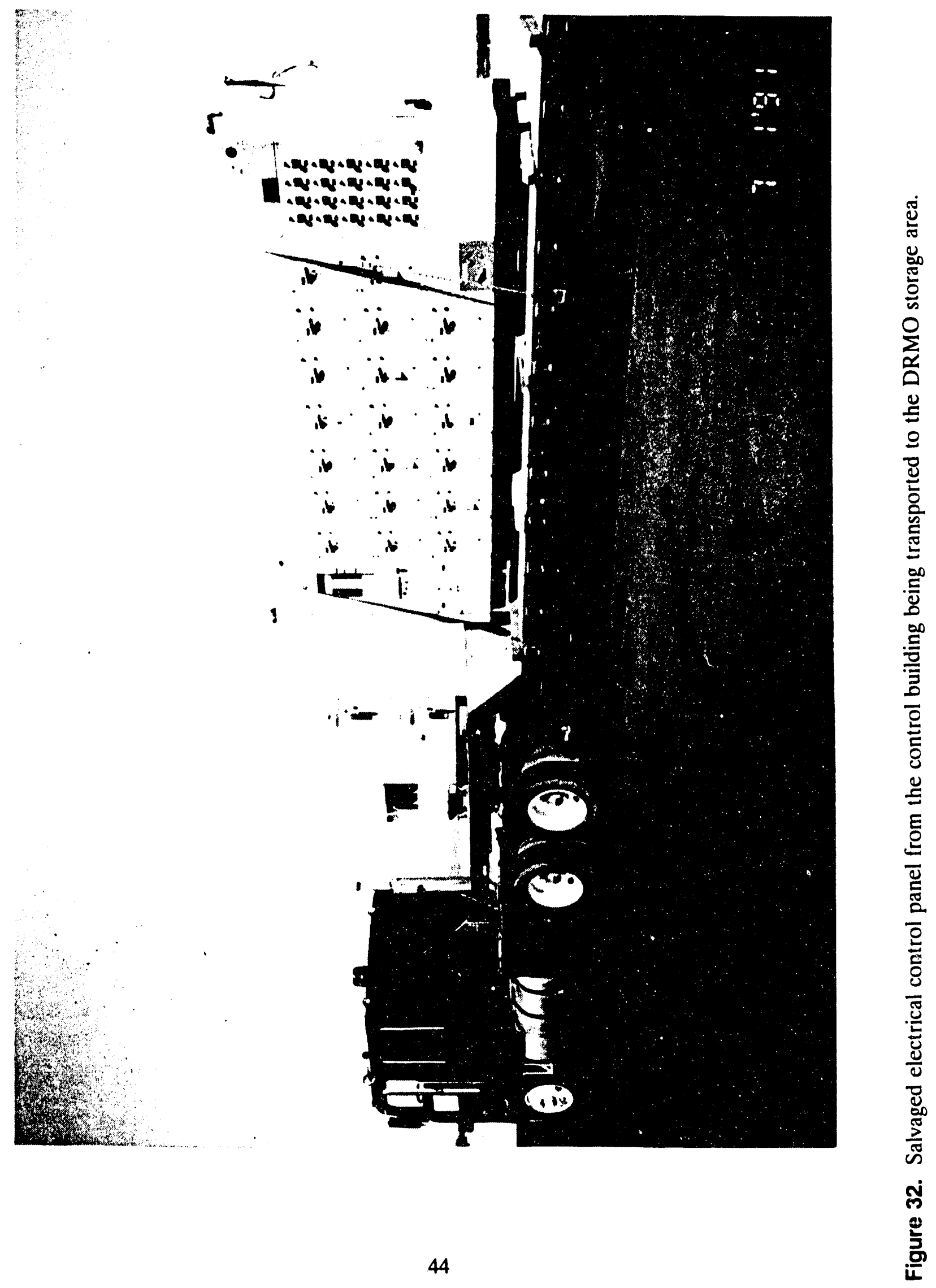




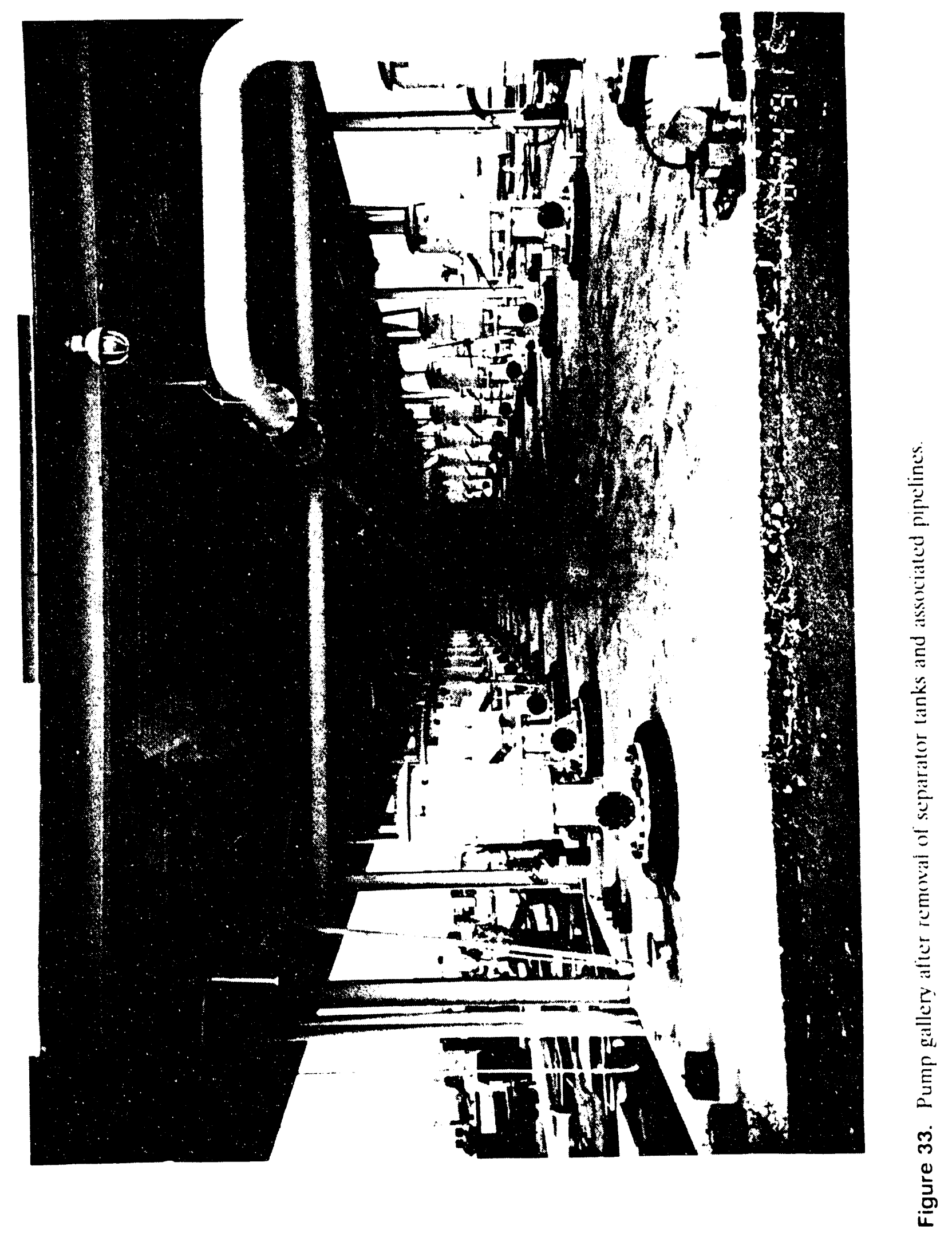




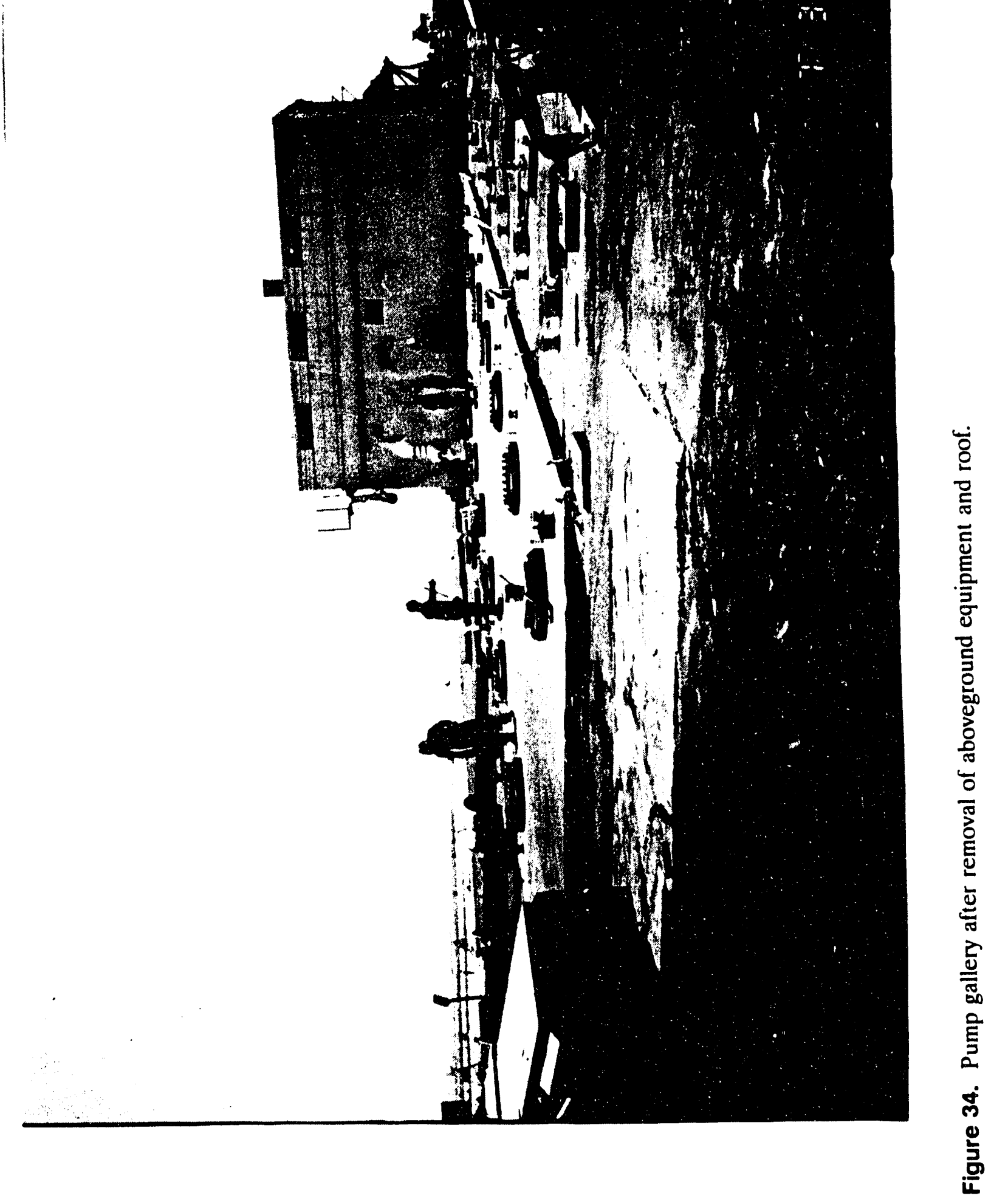




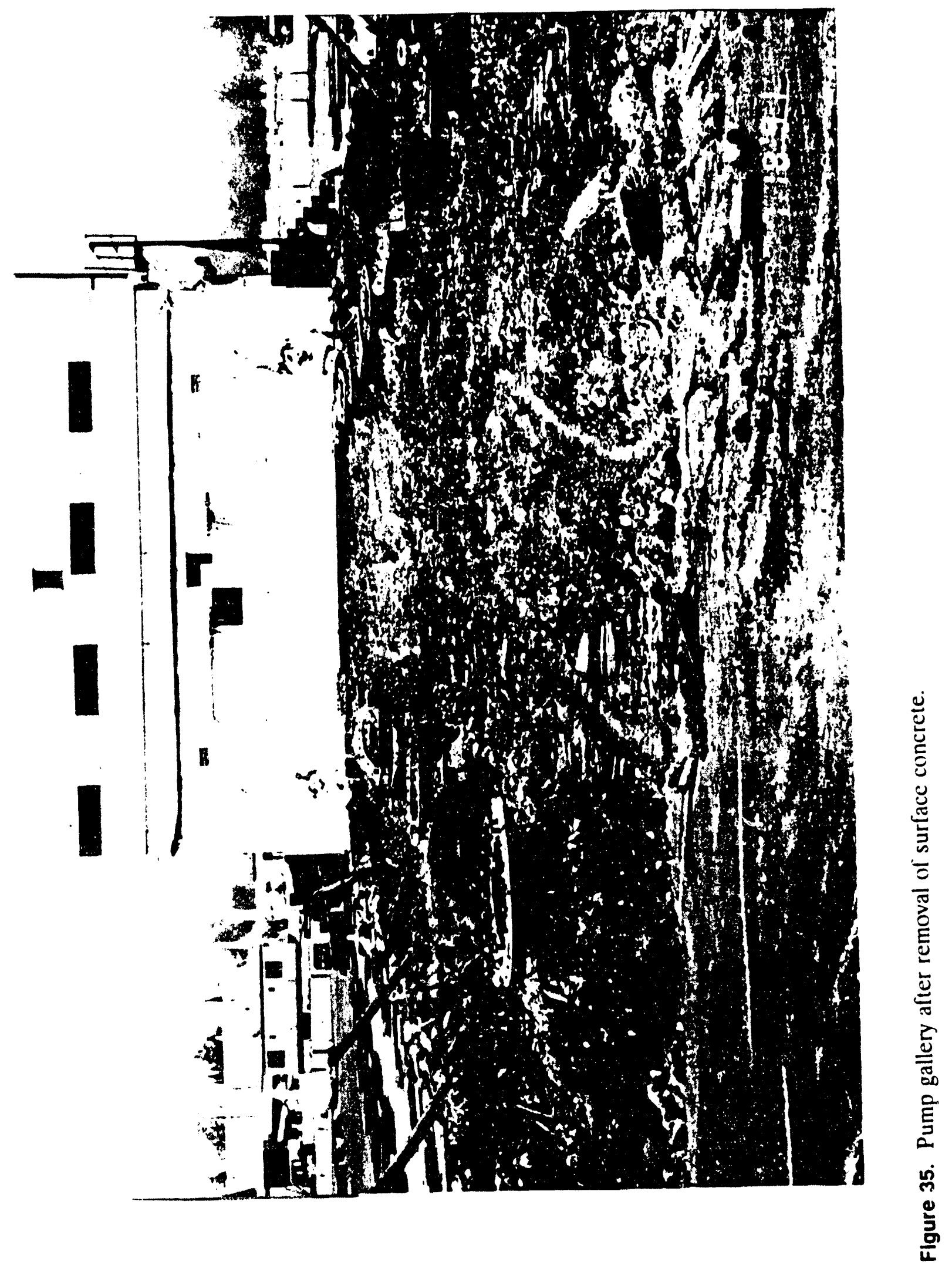




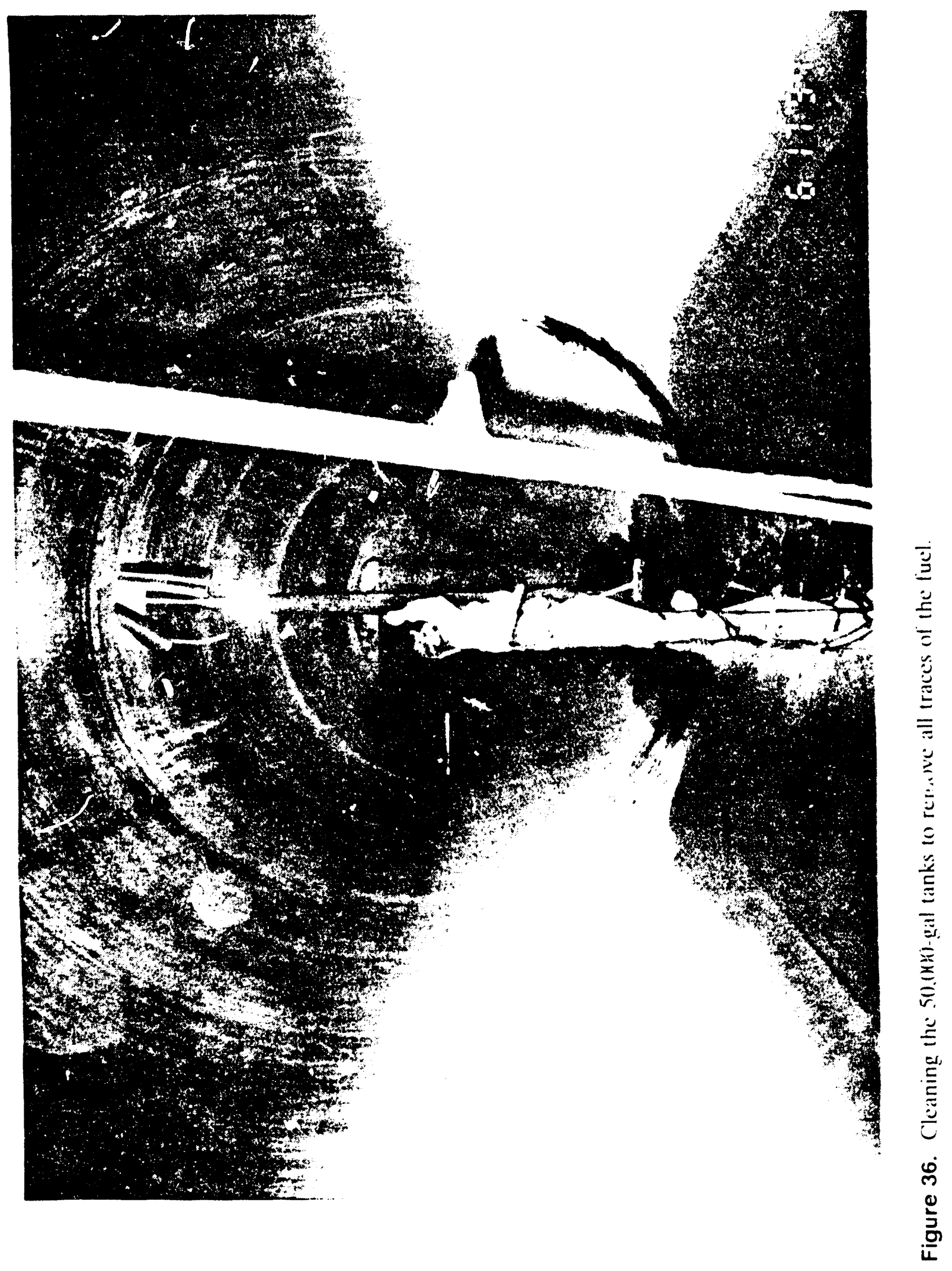




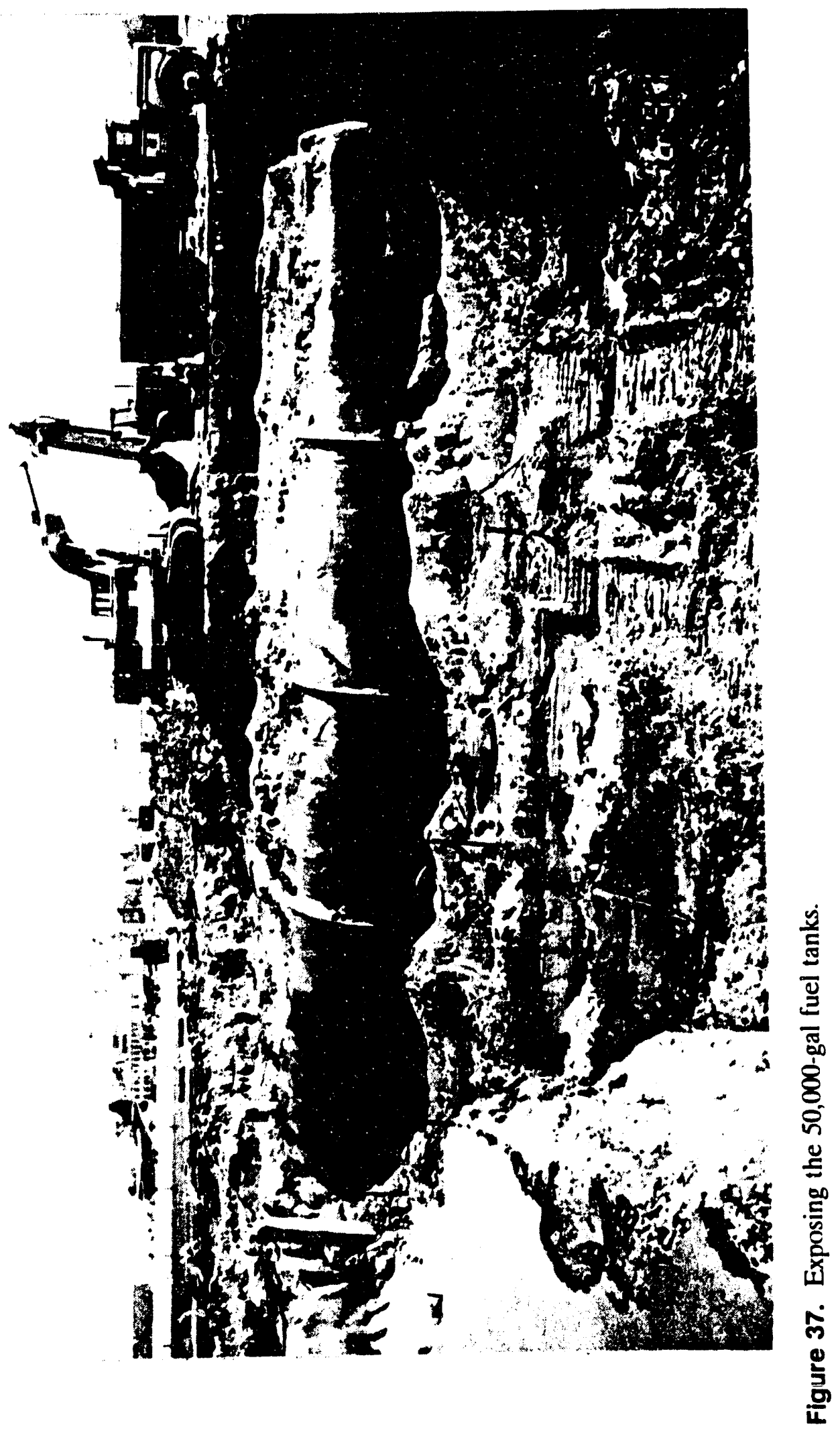




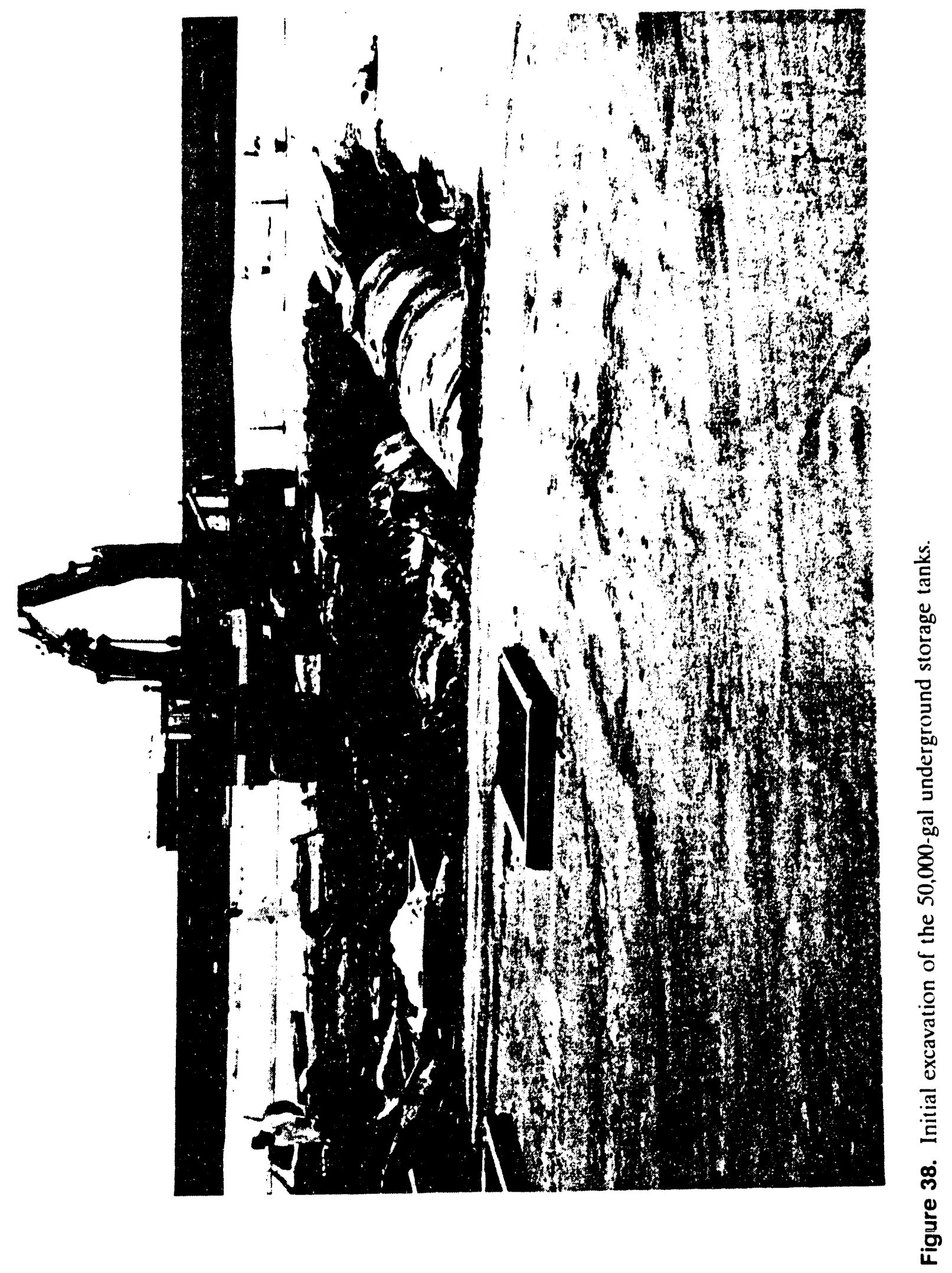




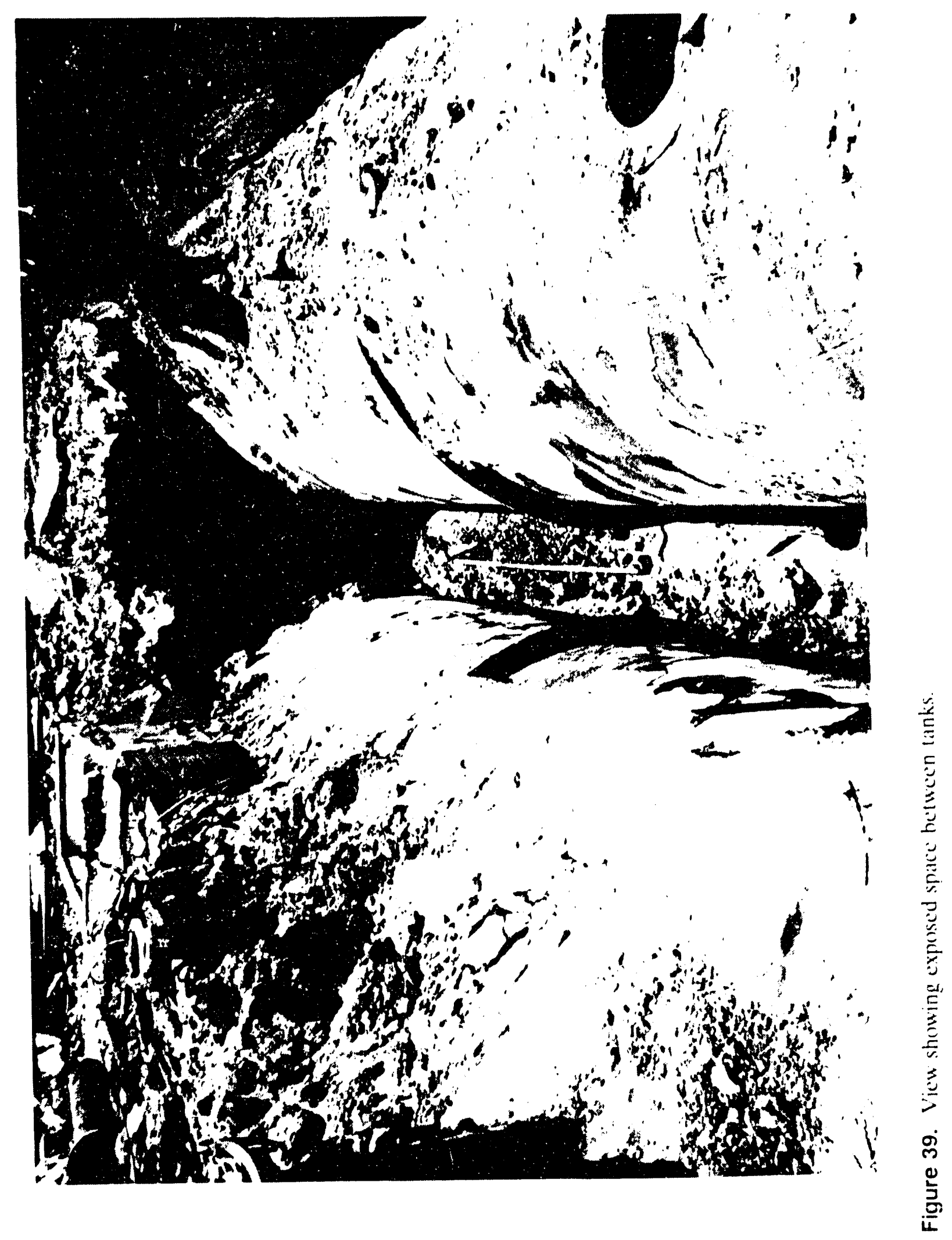




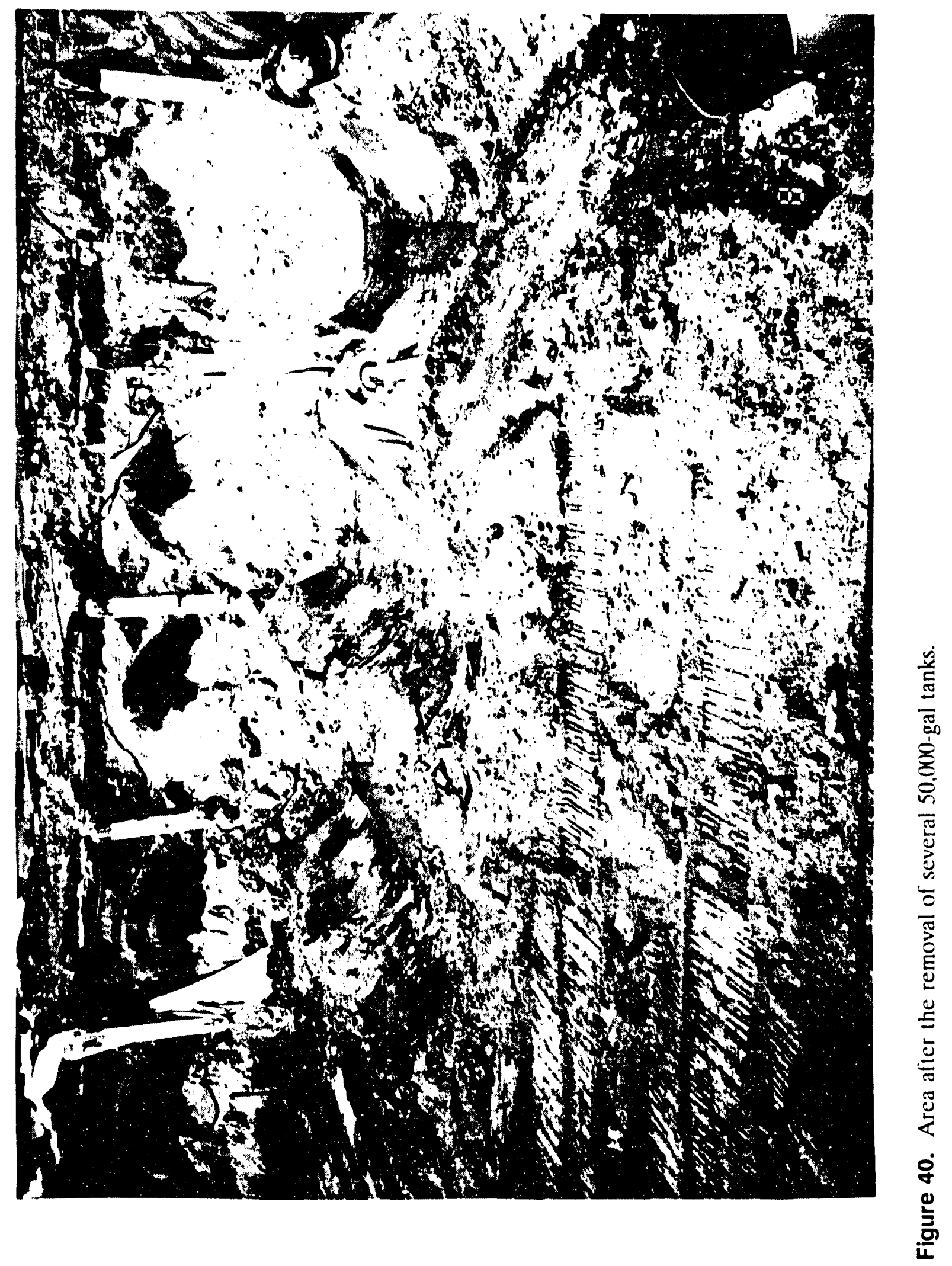




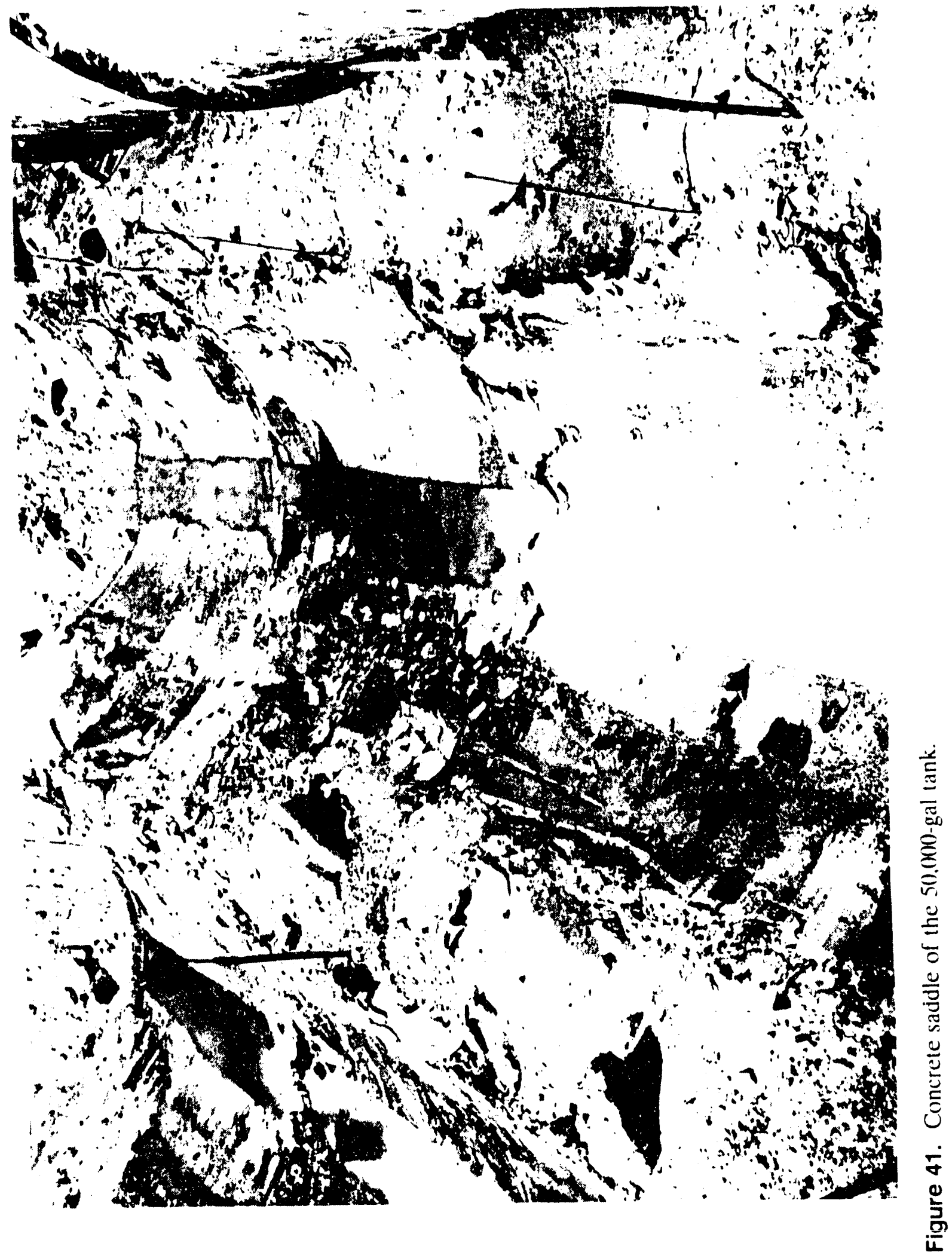




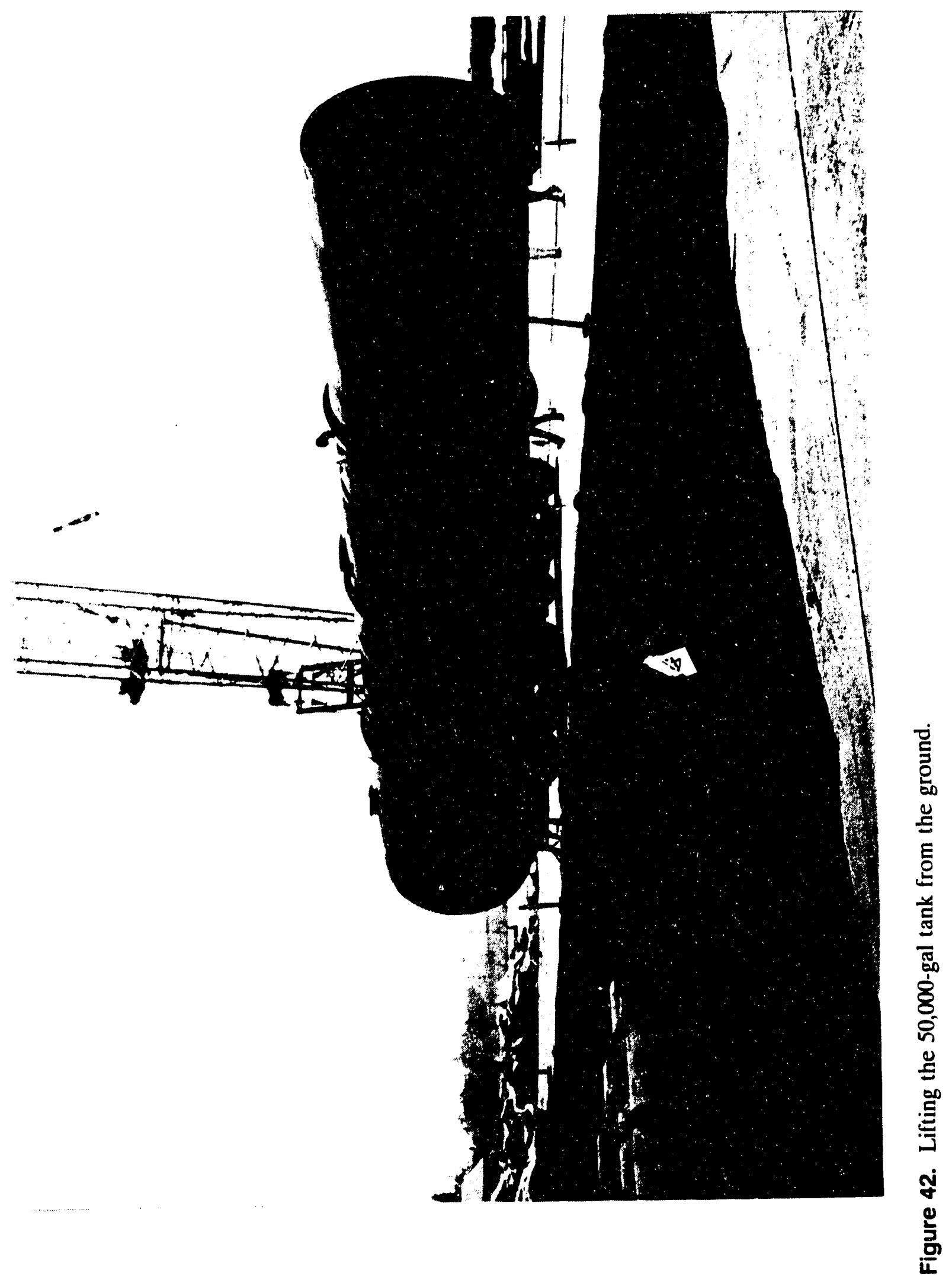




\subsection{Defueling Tank}

- The associated piping and components were removed and deposited at a State of California approved landfill.

- The concrete structure was removed and the material deposited at a State of California approved landfill.

- The 25,000-gal underground storage tank was removed, cleaned, and dislocated from March AFB.

\subsection{Underground Piping}

- The concrete and soil covering the remaining underground pipelines were removed and the pipes exposed. All remaining fuel, fuel vapors, and other liquids were removed from the lines.

- The pipelines to be removed were exhumed and the lines to be abandoned in-place were filled with grout. The abandoned lines were then capped or plugged.

Figures 43 through 45 show some of the work required in removing the underground pipes.

\subsection{Backfill and Compaction}

- All excavations were backfilled with clean soil, compacted, and graded. A soil binder was incorporated into the last stratum to prevent migration.

- Figures 46 through 50 show various operations during the backfill and compaction process of the area that previously contained the pump system and 50,000-gal underground storage tanks. 


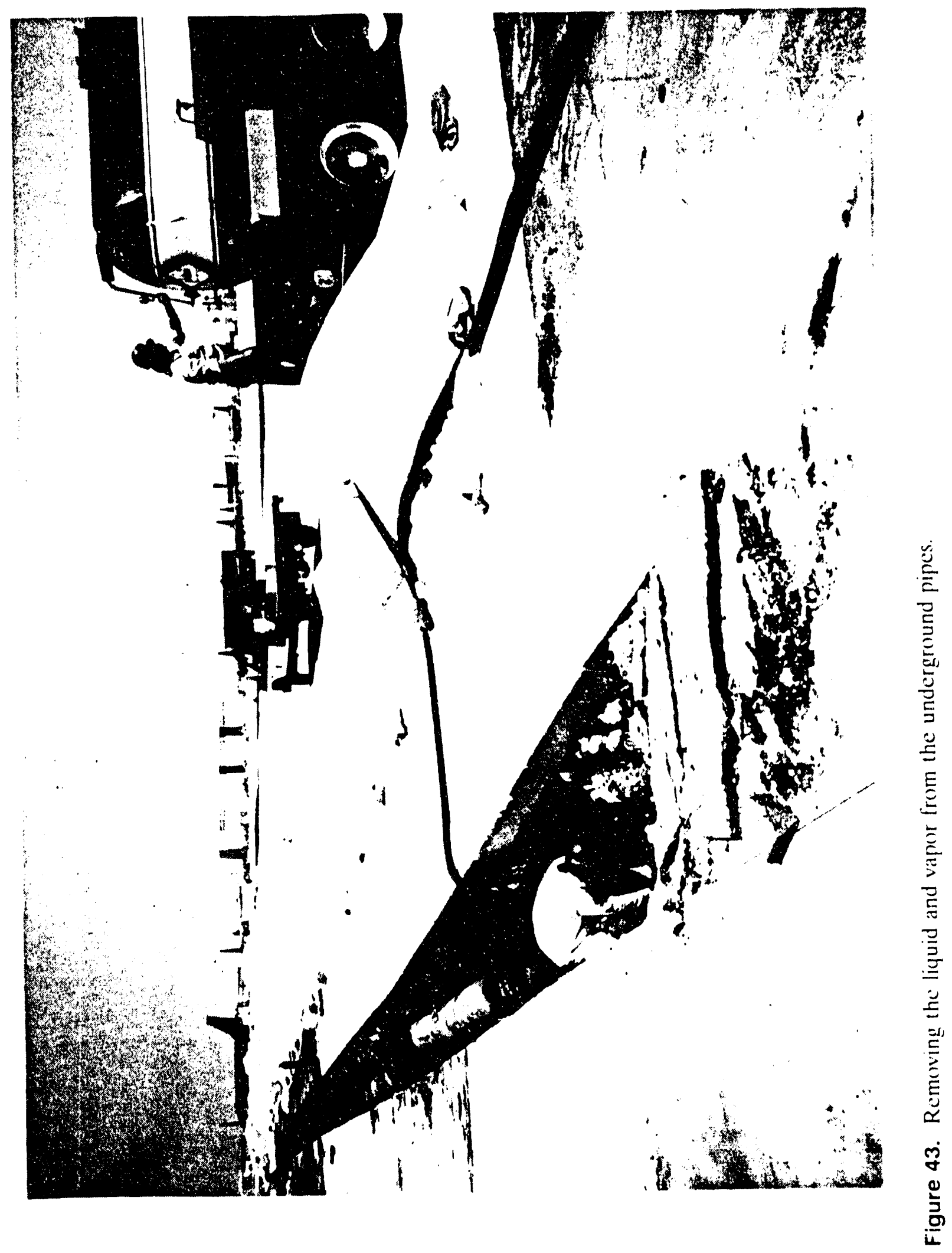




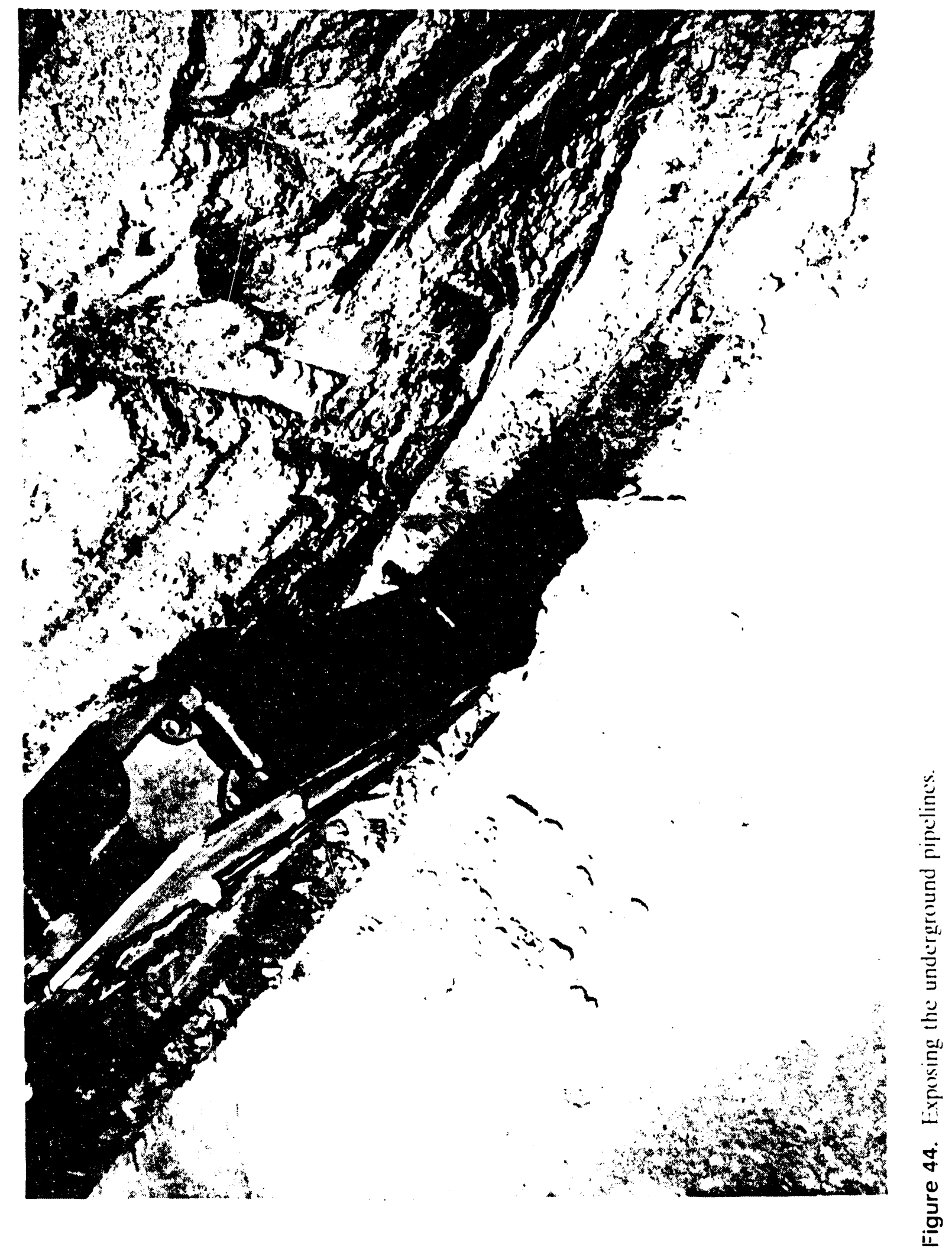




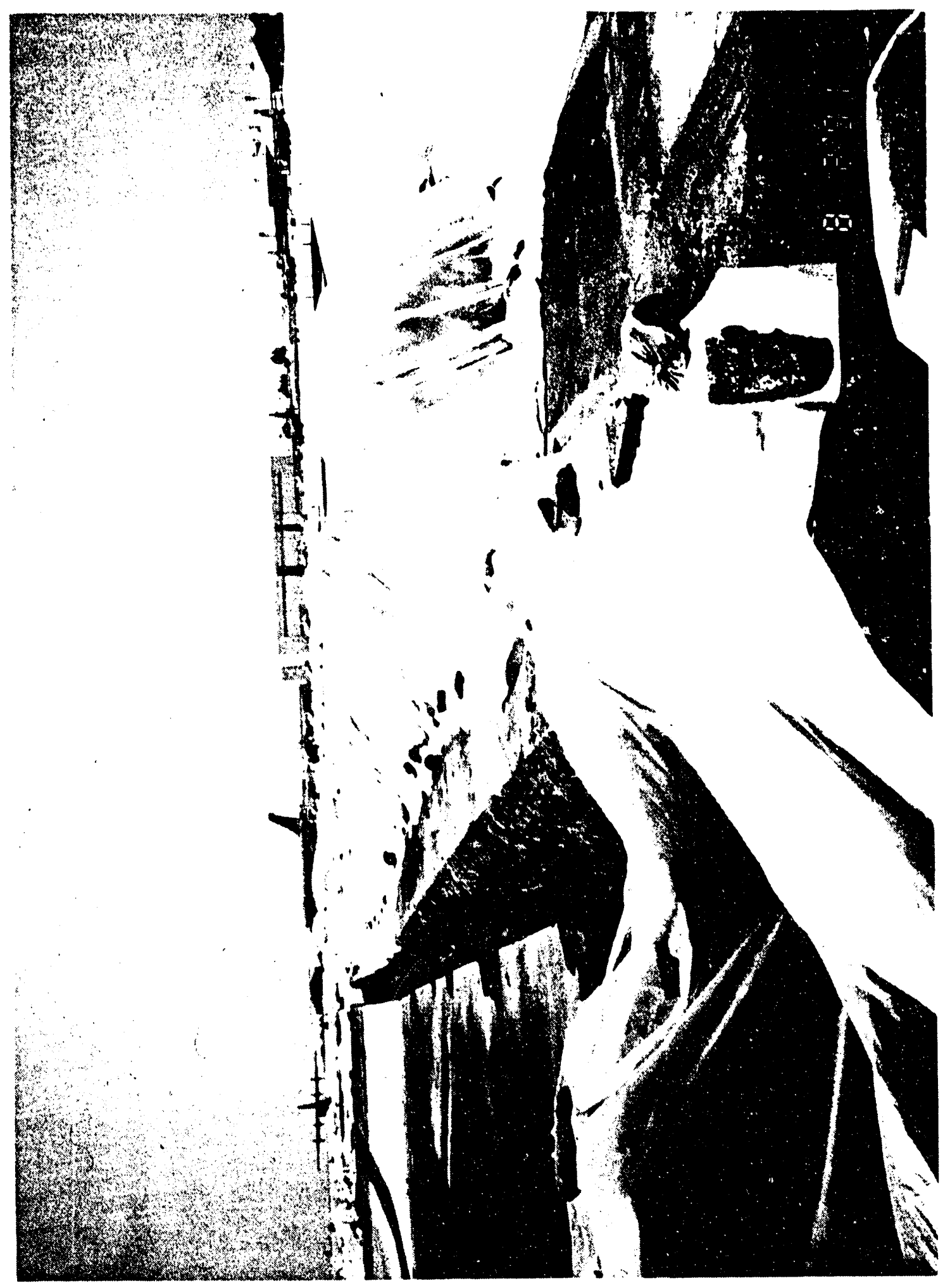

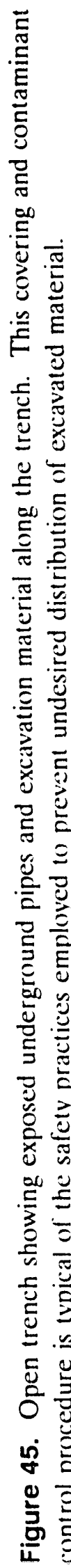




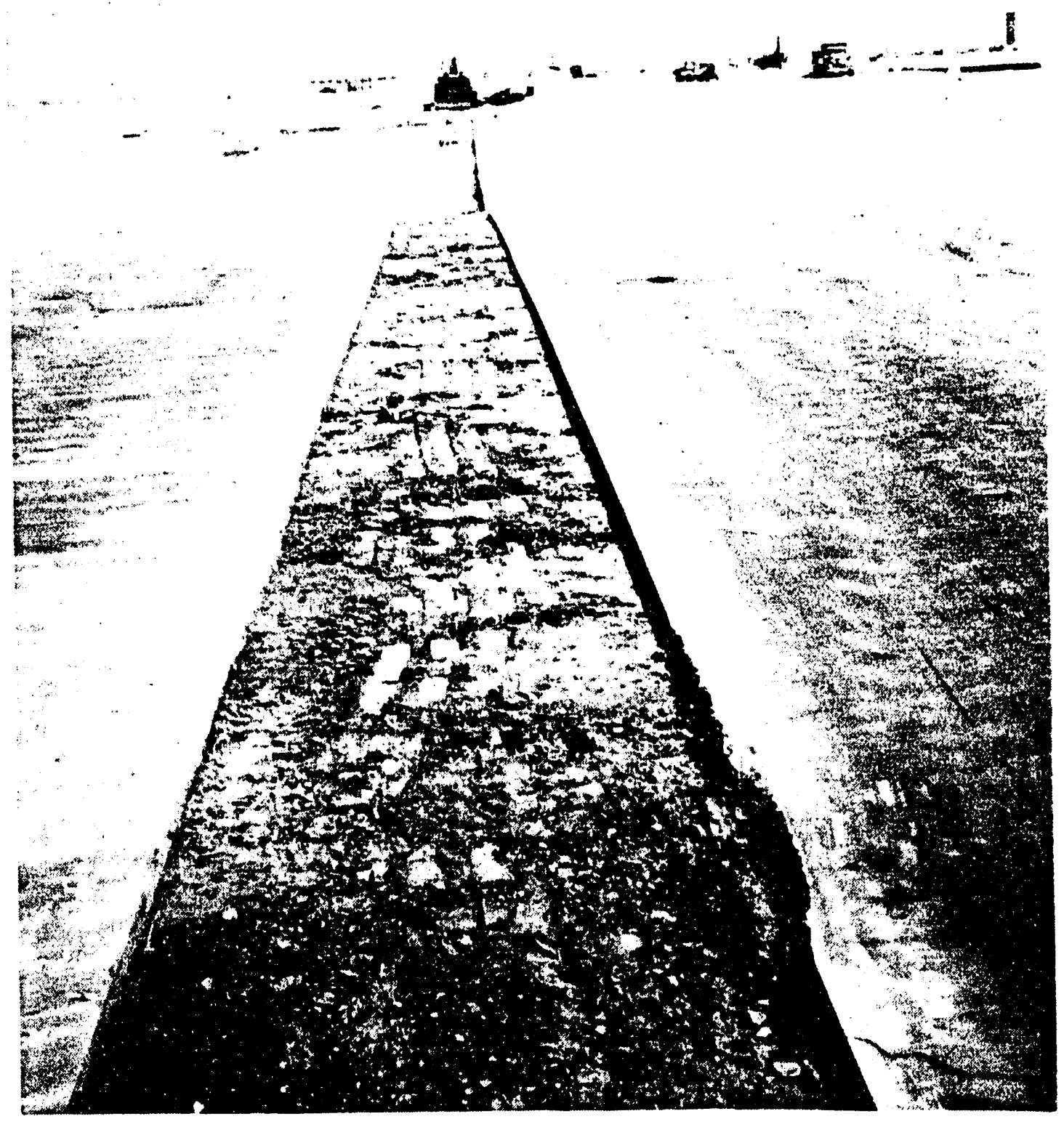

Figure 46. Backfill and grading of the underground pipeline section. 


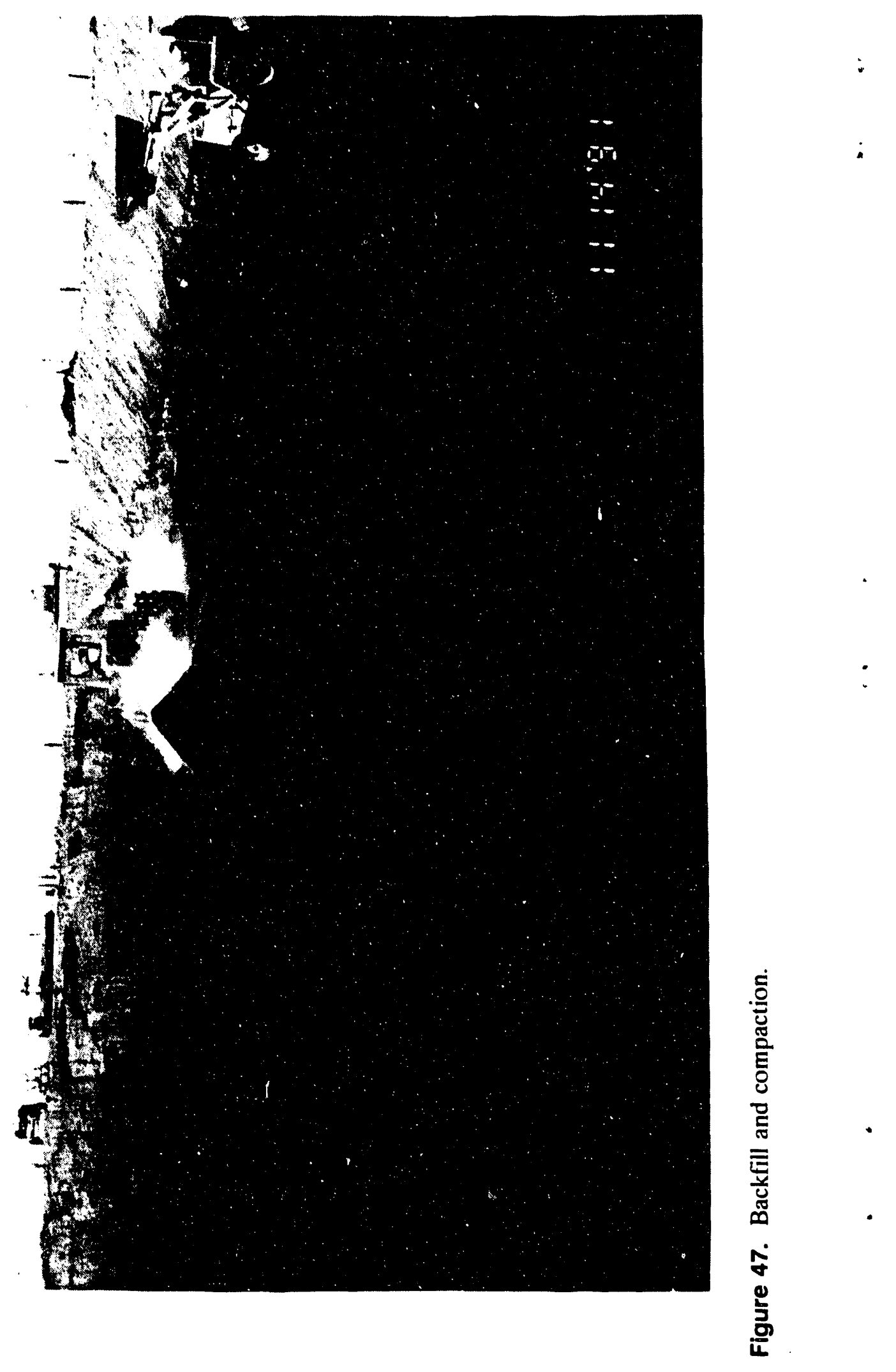




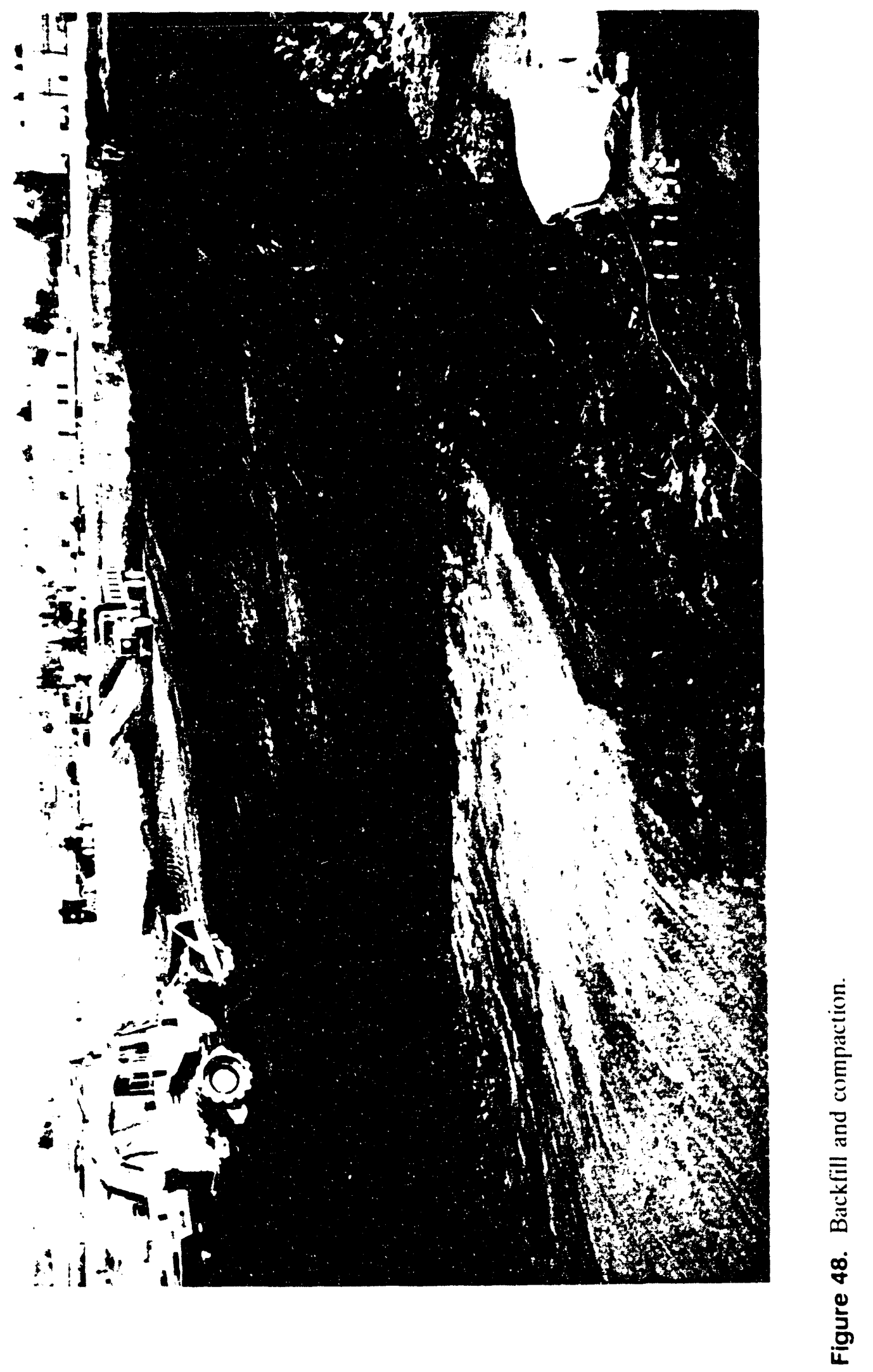




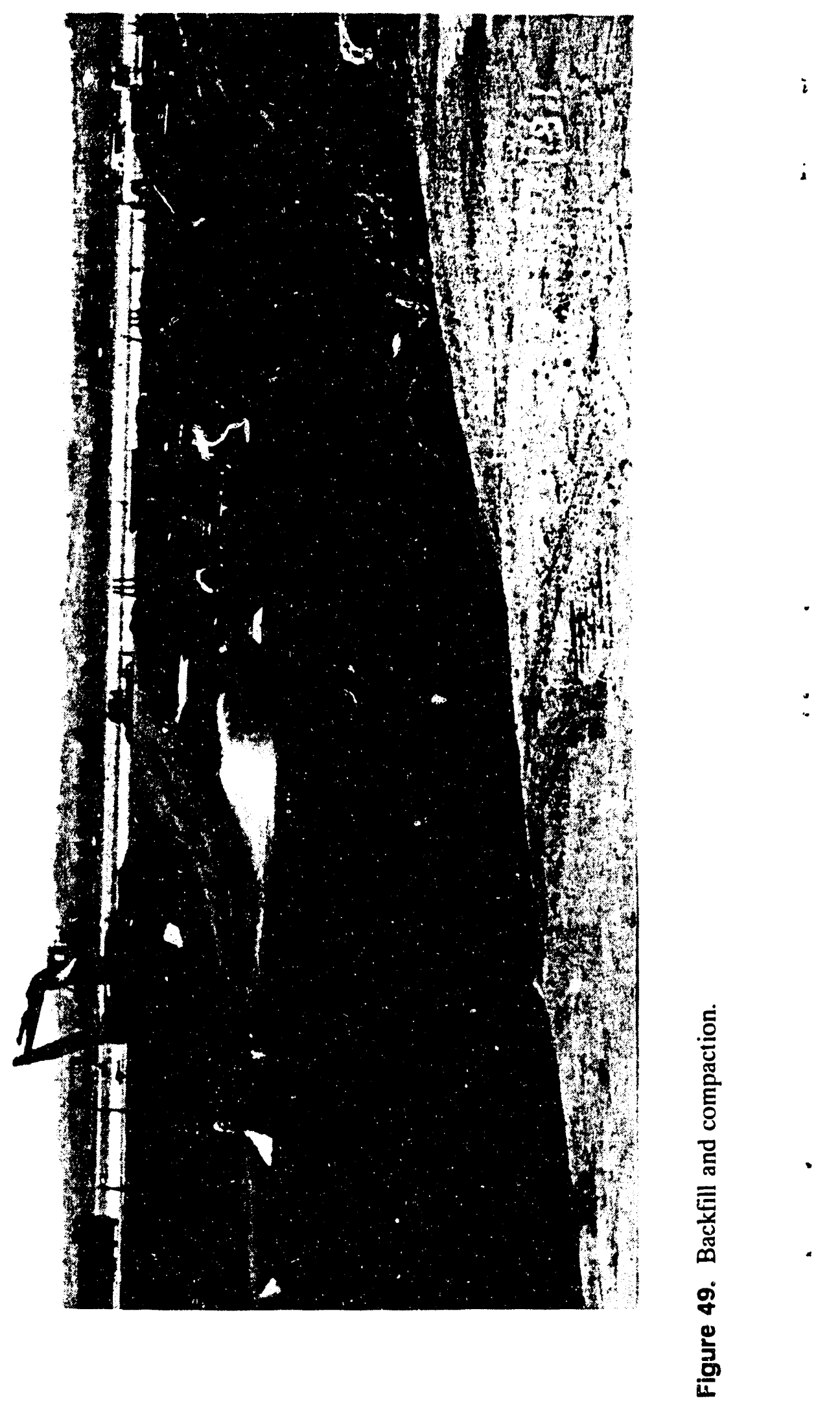




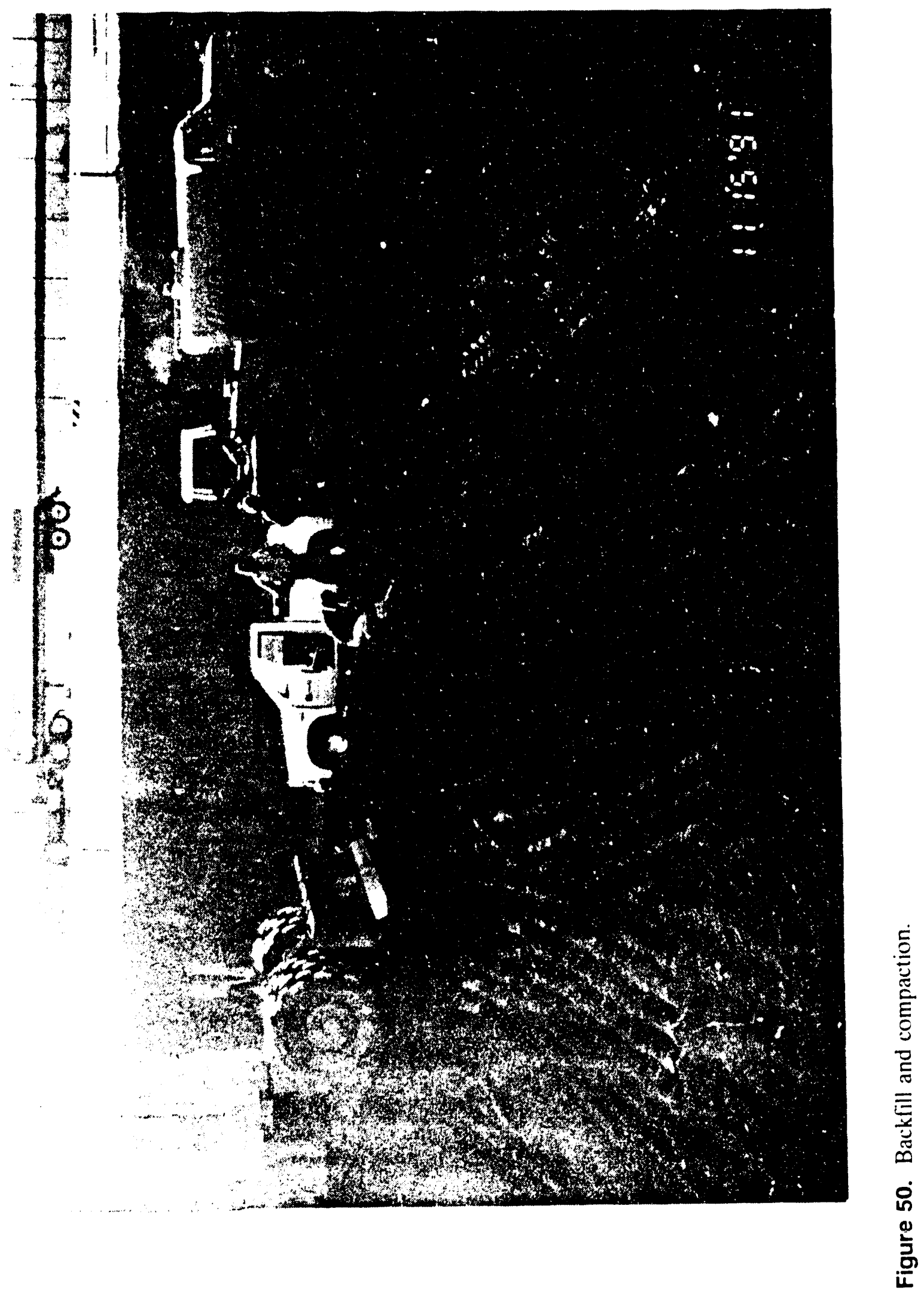




\section{WASTE REDUCTION ACTIONS}

Several procedures were invoked to reduce the amount of waste in the removal process.

- The salvageable material was identificd and sent to the Defense and Reutilization Marketing Office.

- Uncontaminated soil was separated from the contaminated soil during excavation and temporarily stored in its own area. It was later used as backfill in the tank area. Soil was sampled and immediately analyzed to differentiate between contaminated and uncontaminated soil.

- Contaminated soil was identified and processed through a low-temperature cleaning process and then returned to the excavations as fill material. Approximately 15,000 tons $\left(\sim 10,000 \mathrm{yd}^{3}\right)$ of petrolcum contaminated soil was treated and cleaned by Ryan-Murphy, Inc. The soil treatment plant (Good Earth Machine [GEM]) is a low-temperature treatment plant.

Figures 51 through 55 show some of the practices invoked in separating contaminated material from clean soil and some of the matcrial saivaged. 


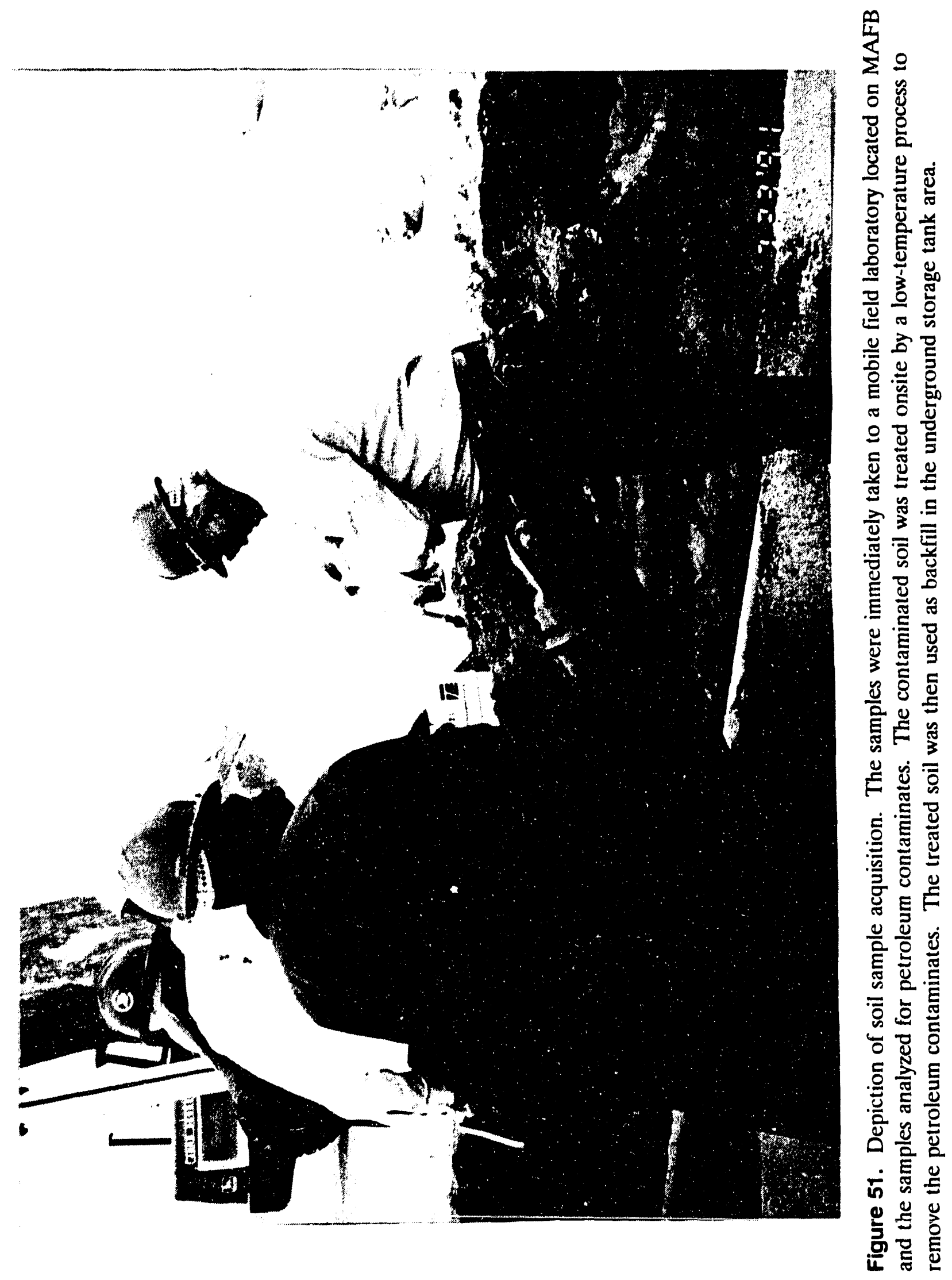




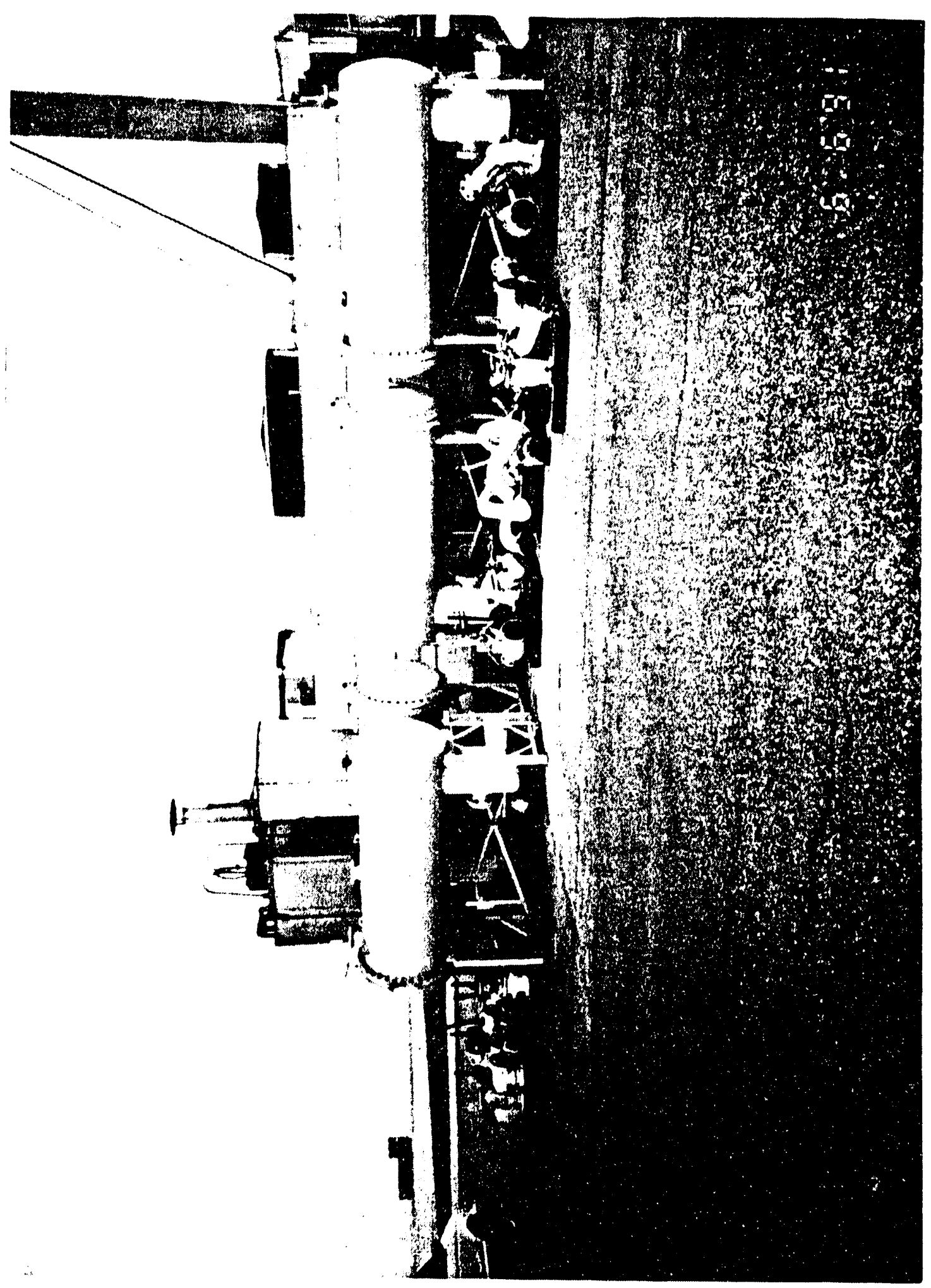

D 


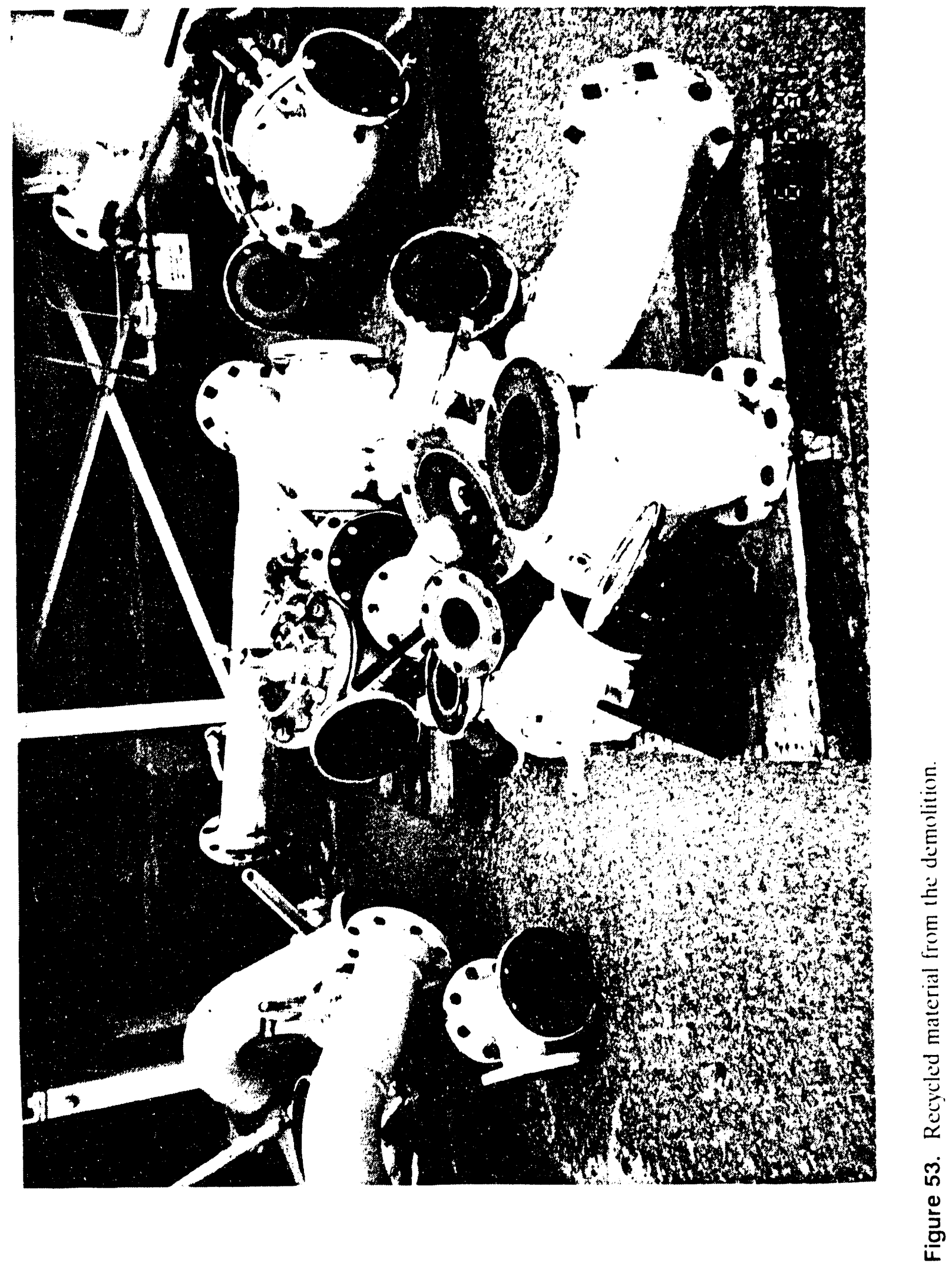




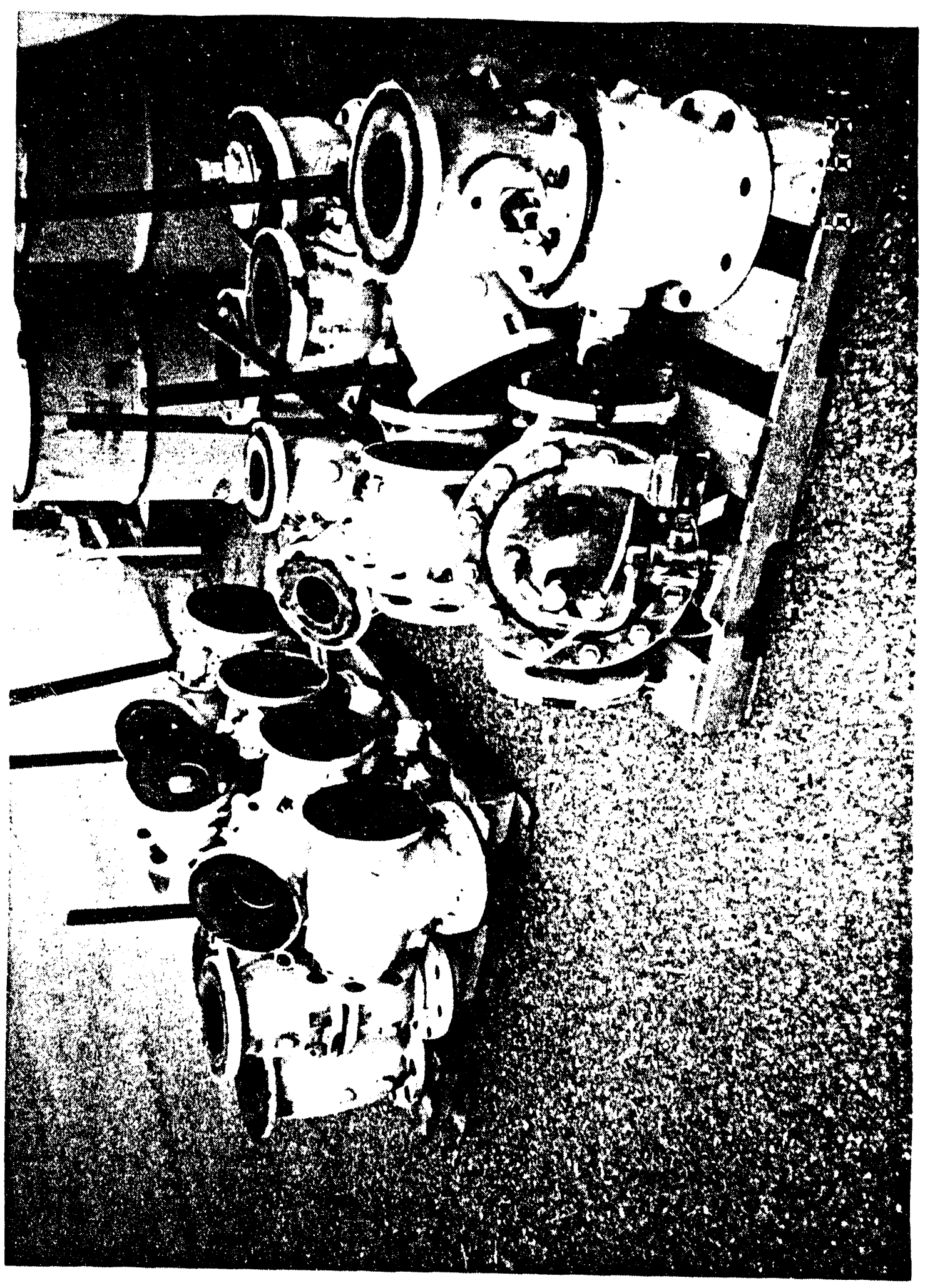

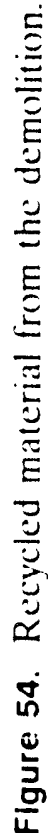




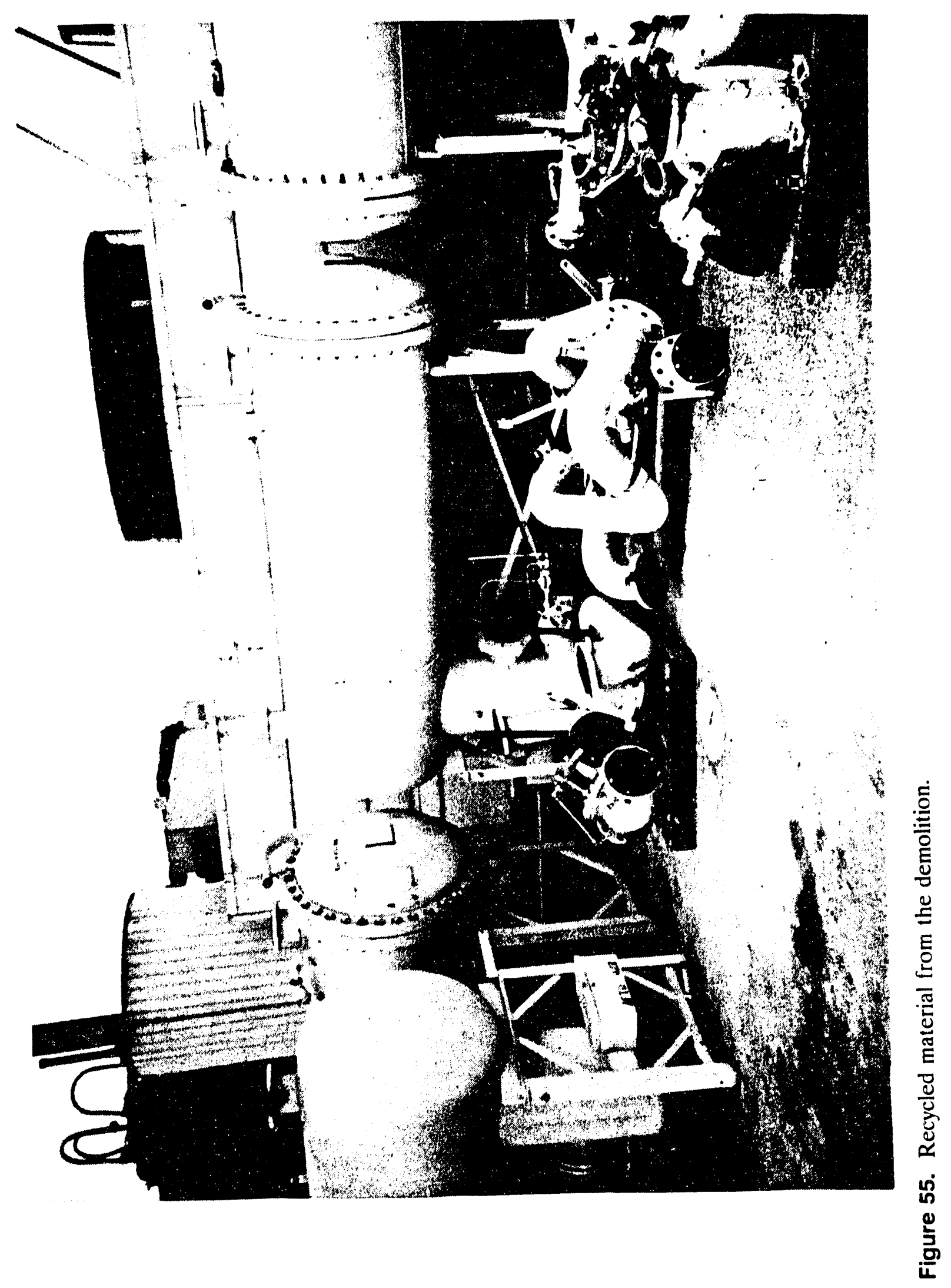




\section{REFERENCES}

Gysler, C. E., 1990, Performance Work Statement Removal of Aircraft Fuel Hydrant System March Air Force Base, California, EG\&G-WM-8882, May.

EG\&G Idaho Inc., 1991, March Air Force Base Operable Unit 3 (Panero Site) Remedial Investigation/Feasibility Study Work Plan Addendum, EGG-CEE-9731, February.

Earth Technology Corporation, 1989, Installation Restoration Program, Stage 4 Remedial Investigation/Feasibility Study (RI/FS) Draft Work Plan for March Air Force Base, California, April.

Earth Technology Corporation, 1992, Installation Restoration Program Base-wide RI/FS Work Plan, March Air Force Base, California.

Engineering-Scirnce, 1988, Installation Restoration Program Phase II -

Confirmation/Quantification, Stage 2, March Air Force Base, California, Final Report, June. 

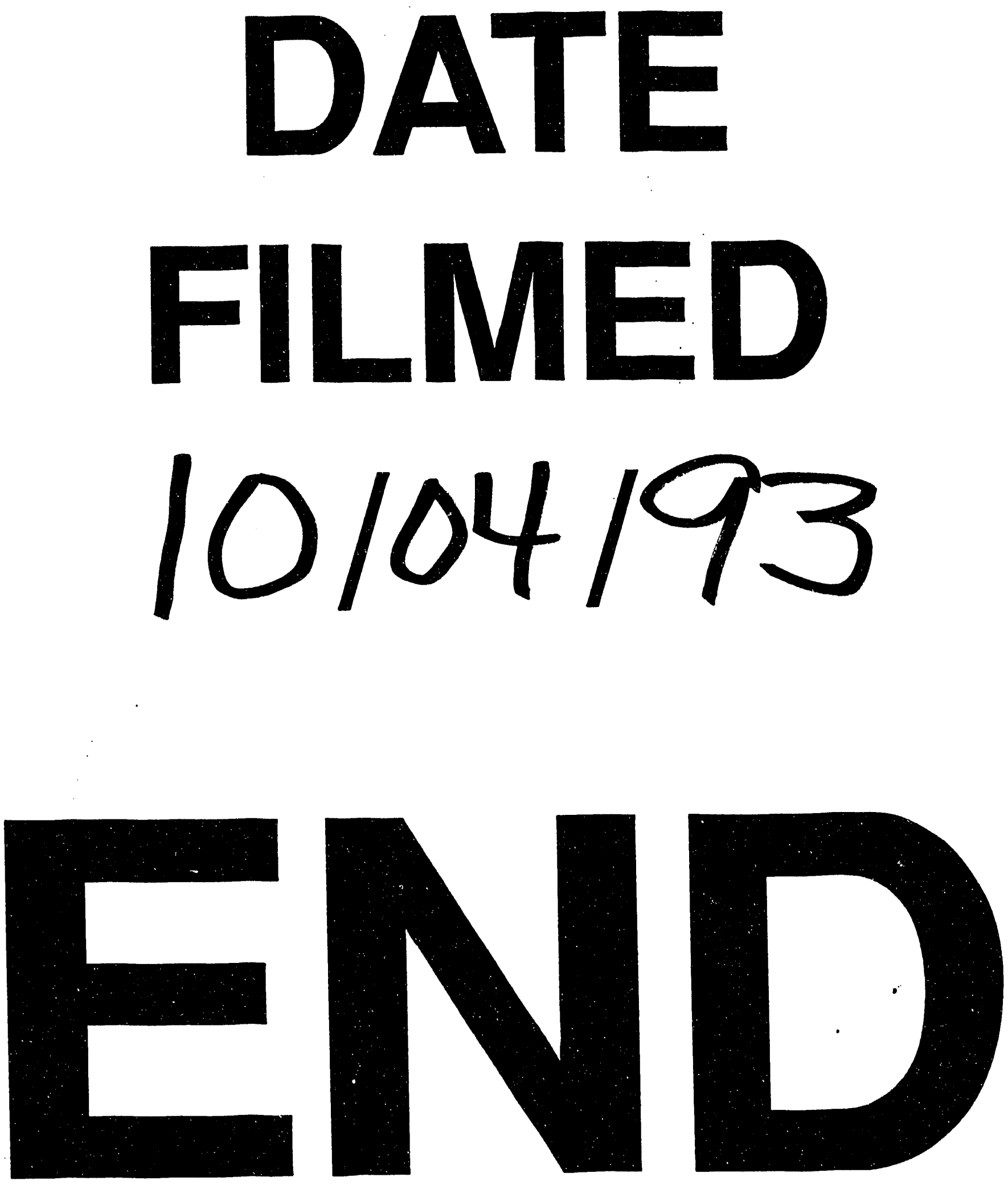
